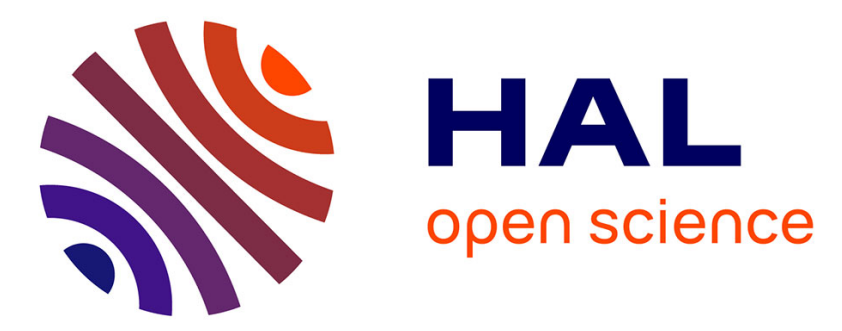

\title{
A comparison of technologies for remediation of heavy metal contaminated soils
}

Sana Khalid, Muhammad Shahid, Nabeel Khan Niazi, Behzad Murtaza, Irshad Bibi, Camille Dumat

\section{To cite this version:}

Sana Khalid, Muhammad Shahid, Nabeel Khan Niazi, Behzad Murtaza, Irshad Bibi, et al.. A comparison of technologies for remediation of heavy metal contaminated soils. Journal of Geochemical Exploration, 2016, 182, pp.247 - 268. 10.1016/j.gexplo.2016.11.021 . hal-01577861v2

\section{HAL Id: hal-01577861 \\ https://hal.science/hal-01577861v2}

Submitted on 22 Nov 2017

HAL is a multi-disciplinary open access archive for the deposit and dissemination of scientific research documents, whether they are published or not. The documents may come from teaching and research institutions in France or abroad, or from public or private research centers.
L'archive ouverte pluridisciplinaire HAL, est destinée au dépôt et à la diffusion de documents scientifiques de niveau recherche, publiés ou non, émanant des établissements d'enseignement et de recherche français ou étrangers, des laboratoires publics ou privés. 


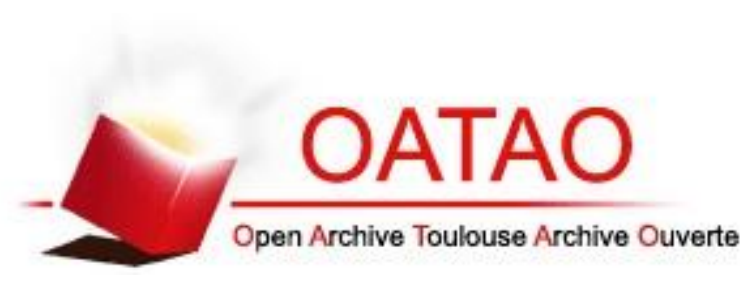

\section{Open Archive Toulouse Archive Ouverte (OATAO)}

OATAO is an open access repository that collects the work of Toulouse researchers and makes it freely available over the web where possible.

This is an author-deposited version published in: http://oatao.univ-toulouse.fr/ Eprints ID: 17423

To link to this article : DOI: $10.1016 /$ j.gexplo.2016.11.021

URL : http://dx.doi.org/10.1016/j.gexplo.2016.11.021

To cite this version: Khalid, Sana and Shahid, Muhammad and Niazi, Nabeel Khan and Murtaza, Behzad and Bibi, Irshad and Dumat, Camille $A$ comparison of technologies for remediation of heavy metal contaminated soils. (2017) Journal of Geochemical Exploration, vol. 182 (part B). pp. 247-268. ISSN 0375-6742

Any correspondence concerning this service should be sent to the repository administrator: staff-oatao@listes-diff.inp-toulouse.fr 


\title{
A comparison of technologies for remediation of heavy metal contaminated soils
}

\author{
Sana Khalid ${ }^{\text {a }}$, Muhammad Shahid ${ }^{\mathrm{a}, *}$, Nabeel Khan Niazi ${ }^{\mathrm{b}, c, \mathrm{~d}}$, Behzad Murtaza ${ }^{\mathrm{a}}$, Irshad Bibi ${ }^{\mathrm{b}, c, \mathrm{~d}}$, Camille Dumat ${ }^{\mathrm{e}}$ \\ a Department of Environmental Sciences, COMSATS Institute of Information Technology, Vehari 61100, Pakistan \\ ${ }^{\mathrm{b}}$ Institute of Soil and Environmental Sciences, University of Agriculture Faisalabad, Faisalabad 38040, Pakistan \\ c Southern Cross GeoScience, Southern Cross University, Lismore 2480, NSW, Australia \\ d MARUM and Department of Geosciences, University of Bremen, Bremen D-28359, Germany \\ e Centre d'Etude et de Recherche Travail Organisation Pouvoir (CERTOP), UMR5044, Université J. Jaurès - Toulouse II, 5 allée Antonio Machado, 31058 Toulouse Cedex 9, France
}

Keywords:

Heavy metal(loid)s

Soil remediation

Remediation techniques

Comparison

\begin{abstract}
A B S T R A C T
Soil contamination with persistent and potentially (eco)toxic heavy metal(loid)s is ubiquitous around the globe. Concentration of these heavy metal(loid)s in soil has increased drastically over the last three decades, thus posing risk to the environment and human health. Some technologies have long been in use to remediate the hazardous heavy metal(loid)s. Conventional remediation methods for heavy metal(loid)s are generally based on physical, chemical and biological approaches, which may be used in combination with one another to clean-up heavy metal(loid) contaminated soils to an acceptable and safe level. This review summarizes the soil contamination by heavy metal(loid)s at a global scale, accumulation of heavy metal(loid)s in vegetables to toxic levels and their regulatory guidelines in soil. In this review, we also elucidate and compare the pool of available technologies that are currently being applied for remediation of heavy metal(loid) contaminated soils, as well as the economic aspect of soil remediation for different techniques. This review article includes an assessment of the contemporary status of technology deployment and recommendations for future remediation research. Finally, the molecular and genetic basis of heavy metal(loid) (hyper)accumulation and tolerance in microbes and plants is also discussed. It is proposed that for effective and economic remediation of soil, a better understanding of remediation procedures and the various options available at the different stages of remediation is highly necessary.
\end{abstract}

\section{Introduction}

Heavy metal(loid)s refer to a group of toxic elements which are both biologically and industrially important. The widespread contamination of soil with heavy metal(loid)s represents currently one of the most severe environmental problems that can seriously affect environmental quality and human health. Heavy metal(loid)s are released into the soils by both natural and anthropogenic sources. Although environmental contamination of heavy metal(loid)s started in ancient times, the problem provoked after the industrial revolution owing to dramatic increase in the use of heavy metal(loid)s in various modern technologies. The current worldwide mine production of heavy metal(loid)s is considerably huge (Shahid et al., 2015a). Heavy metal(loid)s commonly present in soils include nickel $(\mathrm{Ni})$, lead $(\mathrm{Pb})$, cadmium $(\mathrm{Cd})$, arsenic (As), chromium $(\mathrm{Cr})$, copper $(\mathrm{Cu})$, cobalt $(\mathrm{Co})$, zinc $(\mathrm{Zn})$, manganese $(\mathrm{Mn})$, aluminum $(\mathrm{Al})$ and mercury $(\mathrm{Hg})$. Among these heavy metal(loid)s, $\mathrm{As}, \mathrm{Pb}, \mathrm{Cd}$ and $\mathrm{Hg}$ are included in the top 20 Hazardous

\footnotetext{
* Corresponding author at: Department of Environmental Sciences, COMSATS Institute of Information Technology, Vehari, Pakistan.

E-mail address: muhammadshahid@ciitvehari.edu.pk (M. Shahid).
}

Substances of the Agency for Toxic Substances and Disease Registry (ATSDR, 2012) and the United States Environmental Protection Agency (US EPA).

Excessive build-up of heavy metal(loid)s in agricultural soils results in increased heavy metal(loid) uptake by food crops and vegetables, which in turn may induce serious health risks to human beings (Xiong et al., 2016a; Pierart et al., 2015). Heavy metal(loid)s are reported to cause several disorders in humans including cardiovascular diseases, cancer, cognitive impairment, chronic anemia, damage of kidneys, nervous system, brain, skin, and bones (Jarup, 2003). Owing to potential toxic effects associated with heavy metal(loid) exposure, there is a global concern to comply that the heavy metal(loid) content of agricultural soil and the crops cultivated on these soils do not exceed the allowable regulatory limits. Moreover, people are becoming more aware of the inferences of heavy metal(loid) contaminated soils on human and environmental health, resulting in the improvement and development of technologies for clean-up of heavy metal(loid) contaminated sites.

Contrasting to organic contaminants, heavy metal(loid)s are somewhat unique by the fact that they are highly resistant to either biologically or chemically induced degradation. Therefore, total heavy metal(loid) contents of soil persist for a long time after being introduced 
into the soil. For example, $\mathrm{Pb}$ has a soil persistence period of 150 5000 years, and has been reported to persist in soil for $>150$ years after sludge application (Nandakumar et al., 1995). Similarly, Cd has a biological half-life of $>18$ years (Förstner, 1995). Soil being most essential component of ecological system is highly contaminated worldwide by heavy metal (loid)s. Excessive accumulation of heavy metal (loid)s in the soils may cause deterioration of the soil ecosystem and create other environmental issues. Soil physico-chemical properties such as $\mathrm{pH}$, electrical conductivity, cation exchange capacity, soil mineralogy, microbial and biological conditions and presence of soil inorganic and organic ligands greatly influence the bioavailable and mobile heavy metal(loid)s in soil (Shahid et al., 2012a, 2012b, 2012c, 2012d; Minnikova et al., 2017). Numerous studies have reported heavy metal (loid)s build up in soil and associated risks to soil fertility/quality and biochemical activities (enzymes and microbes). Heavy metal(loid)s at the higher concentration are known to influence the microbial population of soil and their associated activities which may directly affect soil fertility (Minnikova et al., 2017). Pattnaik and Equeenuddin (2016) reported that soil enzyme activities are significantly negatively correlated with metal contents of $\mathrm{Ni}, \mathrm{Cu}, \mathrm{Cr}, \mathrm{Co}, \mathrm{Mn}$ and $\mathrm{Zn}$. The decrease in the activities of enzymes follows the following order: urease $>$ acid phosphatase $\geq$ dehydrogenase $>\beta$-glucosidase $\geq$ alkaline phosphatase. Minnikova et al. (2017) showed that the integrated biological index correlates with the total technogenic pollution index and soil contamination with heavy metals.

Therefore, it is imperative to deploy innovative and site-specific remediation technologies which could feasibly and efficiently remediate heavy metal(loid) contaminated soils. Numerous soil remediation techniques have been developed during the last two decades (Verbruggen et al., 2009; Murtaza et al., 2014; Sabir et al., 2015). These techniques aim to reduce the total and/or bioavailable fractions of heavy metal(loid)s in soils and their subsequent accumulation in the food-chain (Bhargava et al., 2012). Conventional techniques to remediate heavy metal(loid)s from contaminated soils are based on physical, chemical and biological methods (Fig. 1), which may be used in combination with one another to remediate contaminated sites. Despite high efficiency, majority of these techniques are costly, environmentally-destructive and time consuming. Financial and technical implications and complexities have made soil clean-up a challenging task. Practical implementation of these conventional soil remediation methods faces several shortcomings and may implicate some level of hazard. This review discusses and compares different technologies nowadays available for heavy metal(loid) remediation in term of mechanisms involved, advantages, limitations, applicability and cost effectiveness. This review can be highly useful for the owners of industrial sites polluted by long term historical pollution, farmers with soils currently polluted with metal(loid)s and interested to improve the quality of their products or urban gardeners who wish to improve the quality of cultivated lands.

\section{Heavy metal(loid)s soil pollution: a global dilemma}

Soils are a main and terminal sink for heavy metal(loid)s released into the environment by anthropogenic activities (Table 1 ). Various countries confronted with heavy metal(loid) soil contamination differ substantially in awareness of the problem and in strategies and technologies to tackle it (Baldantoni et al., 2016; Myoung Soo Ko et al., 2015). It is reported that $>10$ million contaminated sites exist worldwide, with $>50 \%$ of the sites contaminated with heavy metal(loid)s (He et al., 2015). Majority of these heavy metal(loid) contaminated sites exist in developed countries i.e., the United States of America (USA), Australia,

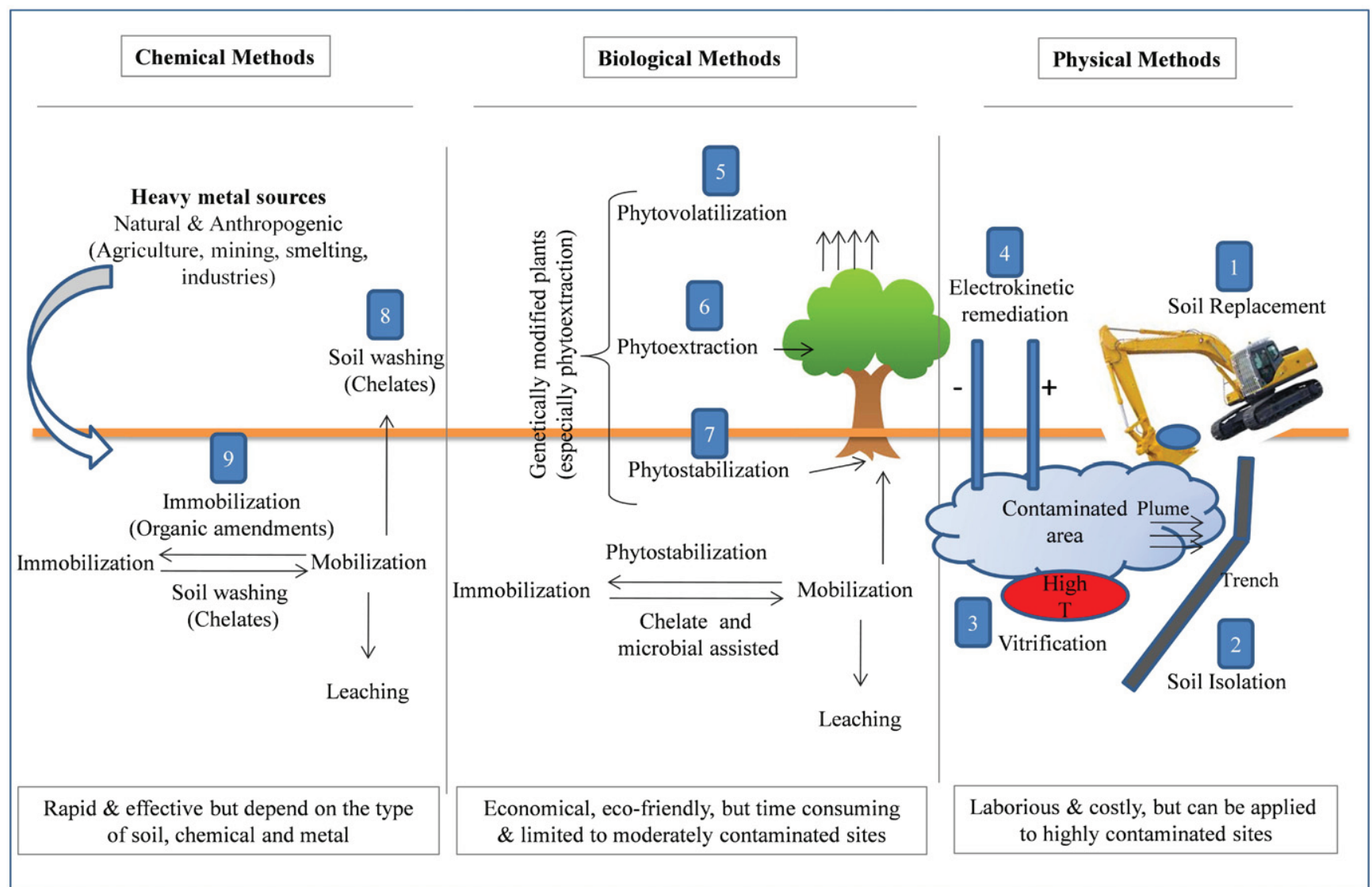

Fig. 1. Comparison of different soil clean-up methods. Soil remediation methods can be broadly divided into three categories: physical, chemical and biological. Physical remediation methods include (1) soil replacement, (2) soil isolation, (3) vitrification, and (4) electrokinetic; biological methods generally include (5) phytostabilization, (6) phytoevaporation and (7) phytoextraction, and chemical methods contain (8) immobilization and (9) soil washing. However, biological and chemical methods can be applied jointly depending on the type of metal, soil, plant and chemical reagent. Moreover, the effectiveness of different phytoremediation techniques can be enhanced by microbial-, chelate- and genetic-assisted remediation. 
Table 1

Examples of some heavy metal(loid)s polluted soils worldwide exceeding permissible limits.

\begin{tabular}{|c|c|c|c|c|c|}
\hline Heavy metal & Concentration in soil $(\mathrm{mg} / \mathrm{kg})$ & Maximum allowable limit $^{\mathrm{a}}$ & Fold-higher than allowable limit & Study area & References \\
\hline \multirow[t]{5}{*}{$\mathrm{Cd}$} & 42 & 3 & 14.0 & Southern Italy & Baldantoni et al., 2016 \\
\hline & 19 & & 6.4 & India & Tiwari et al., 2011 \\
\hline & 16 & & 5.4 & Switzerland & Quezada-Hinojosa et al., 2015 \\
\hline & 14 & & 4.7 & Mexico & Torres et al., 2012 \\
\hline & 14 & & 4.6 & China & Shi et al., 2015 \\
\hline \multirow[t]{5}{*}{$\mathrm{Pb}$} & 4500 & 100 & 45.0 & China & Luo et al., 2011 \\
\hline & 1988 & & 19.9 & China & Niu et al., 2015 \\
\hline & 711 & & 7.1 & UK & Nabulo et al., 2011 \\
\hline & 452 & & 4.5 & Uganda & Nabulo et al., 2012 \\
\hline & 302 & & 3.0 & Brazil & Carvalho et al., 2014 \\
\hline \multirow[t]{5}{*}{ As } & 7490 & 20 & 374.5 & Spain & Beesley et al., 2014 \\
\hline & 4357 & & 217.9 & Italy & Marabottini et al., 2013 \\
\hline & 354 & & 17.7 & China & Wei et al., 2015 \\
\hline & 131 & & 6.6 & Korea & Myoung Soo Ko et al., 2015 \\
\hline & 64 & & 3.2 & Bolivia & Acosta et al., 2015 \\
\hline \multirow[t]{5}{*}{$\mathrm{Zn}$} & 3833 & 300 & 12.8 & China & Niu et al., 2015 \\
\hline & 370 & & 1.2 & Nigeria & Obiora et al., 2016 \\
\hline & 1168 & & 3.9 & Germany & Shaheen et al., 2014 \\
\hline & 905 & & 3.0 & Portugal & Anjos et al., 2012 \\
\hline & 393 & & 1.3 & - & Kwon et al., 2015 \\
\hline \multirow[t]{5}{*}{$\mathrm{Ni}$} & 2603 & 50 & 52.1 & Mexico & Torres et al., 2012 \\
\hline & 373 & & 7.5 & Spain & Arenas-Lago et al., 2016 \\
\hline & 201 & & 4.0 & Zimbabwe & Mapanda et al., 2007 \\
\hline & 200 & & 4.0 & Turkey & Avci and Deveci, 2013 \\
\hline & 153 & & 3.1 & China & Wang et al., 2015 \\
\hline \multirow[t]{4}{*}{$\mathrm{Cu}$} & 35,582 & 100 & 355.8 & Mexico & Torres et al., 2012 \\
\hline & 19,581 & & 195.8 & Australia & Sacristán et al., 2016 \\
\hline & 448 & & 4.5 & China & Wang et al., 2015 \\
\hline & 235 & & 2.4 & Portugal & Anjos et al., 2011 \\
\hline \multirow[t]{4}{*}{$\mathrm{Cr}$} & 4309 & 100 & 43.1 & Spain & Arenas-Lago et al., 2016 \\
\hline & 590 & & 5.9 & China & Xu et al., 2014 \\
\hline & 418 & & 4.2 & Greece & Panagopoulos et al., 2015 \\
\hline & 224 & & 2.2 & Germany & Shaheen et al., 2014 \\
\hline
\end{tabular}

a World Health Organization (WHO), Food and Agricultural Organization (FAO).

Germany, Sweden and China owing to their increased use in industrial processes (Foucault et al., 2013; Goix et al., 2014). In the USA, around 600,000 ha area (especially brown field sites) has been contaminated with heavy metal(loid)s. The US EPA has designated $>50,000$ priority heavy metal(loid) polluted sites awaiting urgent remediation in the USA alone (Ensley, 2000). Gorospe (2012) analysed 16 different heavy metal(loid)s in soil samples collected from 91 vegetable gardens in San Francisco, USA. They observed that majority (>75\%) of the gardens surpassed the California Human Health Screening Level for Cd (84\%), As (74\%) and $\mathrm{Pb}$ (62\%). Similarly, several heavy metal(loid) contaminated agricultural sites situated near mining areas have been reported in different countries of Europe (Foucault et al., 2013; Goix et al., 2014). According to the European Environmental Agency (EEA, 2007), there exist $>3$ million potentially polluting activity sites in Europe and about 250,000 heavy metal(loid)s polluted sites in the EEA member countries. More than 80,000 sites have been cleaned-up in Europe during the last 30 years (EEA, 2007). Approximately 0.5 million sites in Europe are highly contaminated and need remediation on priority basis. It is estimated that the total number of polluted sites needing remediation may increase by $>50 \%$ by 2025 (EEA, 2007). Tóth et al. (2016) conducted the first harmonized topsoil sampling from approximately 22,000 locations and reported that an estimated $6.24 \%$ or $137,000 \mathrm{~km}^{2}$ needs local assessment and remediation action.

In addition to these already recorded polluted sites, around three million sites in Europe are possibly polluted, based on the information about potentially polluting activities on site (Jensen et al., 2009). Poland and Greece each reported $>10,000$ contaminated sites, while Portugal and Ireland each reported $>10,000$ contaminated land areas (Perez, 2012). In France, 11,400 agricultural soil samples were analysed for $\mathrm{Pb}$ contamination and it was observed that about $1 \%$ of soil samples exceeded the French limit values for $\mathrm{Pb}\left(100 \mathrm{mg} \mathrm{kg}^{-1}\right.$ dry weight soil) (Mench and Baize, 2004). According to The French Ministry of Ecology, Sustainable Development and Energy, there are roughly 5759 polluted or potentially polluted sites in France, heavy metal(loid)s being the most prevalent pollutants (60.13\%) in these sites (Agnello et al., 2015). BASOL (Base de données sur les sites et sols pollués), an inventory of polluted sites calling for action by the authorities, reported about 4300 polluted sites in France. The Campine area $\left(700 \mathrm{~km}^{2}\right)$ in the Netherlands and Belgium is contaminated by atmospheric deposition of $\mathrm{Pb}$, Zn and Cd (Meers et al., 2010). In Germany, soil pollution by high levels of heavy metal(loid) contamination has taken out of food production about 10,000 ha of agricultural land (Lewandowski et al., 2006). A survey backed by the European Commission has estimated that society's loss due to soil contamination is about 17.3 billion euros per year.

The situation of soil contamination by heavy metal(loid)s is more worse in China. Approximately 4 mha of arable land (2.9\% of China's arable lands) has been polluted moderately or severely by pollutants as reported jointly by the Ministry of Land Resources of China and the Ministry of Environmental Protection of China (Bulletin on National Survey of Soil Contamination). It is reported that $>20,000,000$ acres of farmland ( $25 \%$ of total arable farmland area) in China has been contaminated by heavy metal(loid)s such as $\mathrm{Pb}, \mathrm{Cd}, \mathrm{Cr}$, Sn and $\mathrm{Zn}$. Heavy metal(loid)s pollution causes $10,000,000$ tons loss of crop output every year in China (Hongbo et al., 2011). According to the Ministry of Environmental Protection and Ministry of Land and Resources (China, 2014), the overstandard rates of $\mathrm{Pb}, \mathrm{Cd}, \mathrm{Cu}$ and $\mathrm{Zn}$ in China were $0.9 \%, 2.1 \%, 7.0 \%$, and $1.5 \%$, respectively. In China, heavy metal(loid)s in $16.1 \%$ farmland soils have exceeded the environmental quality standard for soil. For agricultural soils, $>19.4 \%$ sites exceeded the environmental quality standard. High levels of heavy metal(loid)s in soil are also reported in less developed countries such as Pakistan, India, Bangladesh etc. In less developed countries, the major source of heavy metal(loid)s in soil is the use of untreated waste water (city as well as industrial) for crop irrigation. Several studies in Pakistan and India reported heavy metal(loid)s build up in soil as a result of crop irrigation by untreated waste water (Khan et al., 2015). In Pakistan, approximately 
$30 \%$ of wastewater is directly used for crop irrigation of 32,500 ha in Pakistan, while $64 \%$ of wastewater is directly discharged into water bodies without any primary treatment (Ensink et al., 2004). About, $26 \%$ of the vegetables cultivated in Pakistan are irrigated with untreated wastewater (Ensink et al., 2004).

\section{Sources of heavy metal(loid)s in soil}

Heavy metal(loid)s occur naturally in Earth crust and are released into soil by various human activities, which have resulted in high heavy metal(loid) contents in soil to toxic levels. The most common heavy metal(loid)s present in polluted soils are in order of $\mathrm{Pb}, \mathrm{Cr}, \mathrm{As}$, $\mathrm{Zn}, \mathrm{Cd}, \mathrm{Cu}$ and $\mathrm{Hg}$. Natural processes also contributes towards heavy metal(loid) contamination of soils.

\subsection{Natural sources}

Heavy metal(loid)s are found naturally in soils resulting from weathering of underlying bedrock. These are generally mined from ores following mineral processing processes (UNEP/GPA, 2004; Shakoor et al., 2015). In rocks, heavy metal(loid)s are found in different chemical forms as ores from which these metals are recovered as minerals (Fuge et al., 1991). In ore forms, heavy metal(loid)s generally occur as sulfides of $\mathrm{Pb}, \mathrm{Co}, \mathrm{Fe}, \mathrm{As}, \mathrm{Pb}-\mathrm{Zn}, \mathrm{Ag}$ and $\mathrm{Ni}$, and oxides of $\mathrm{Se}$, $\mathrm{Al}, \mathrm{Mn}$ and $\mathrm{Sb}$. These metals are therefore generally recovered/mined from soils as oxide and sulfide ores. In soils, generally the sulfides of metals (such as $\mathrm{As}, \mathrm{Hg}, \mathrm{Pb}, \mathrm{Cd}$ ) occur naturally together with sulfides of $\mathrm{Cu}$, (chalcopyrite, $\mathrm{CuFeS}_{2}$ ) and $\mathrm{Fe}$ (pyrite, $\mathrm{FeS}_{2}$ ). Therefore, mostly these heavy metal(loid)s are obtained as part of exhaust fumes in pyro metallurgical processes or as by-products of several hydro metallurgical processes after mining. For example, $\mathrm{Cd}$ is mainly obtained as by-product of the $\mathrm{Zn}$ refining process, owing to co-occurrence of $\mathrm{Cd}$ with the Zn ore sphalerite. Every year, significant amount of heavy metal(loid)s is thus redistributed from the contaminated aquifer of Earth's crust to different compartments of environment i.e., water, air and soil. Therefore, soils originating from parent material having an elevated metal concentration in soil bedrocks show high metal concentration naturally (Pourrut et al., 2011a, 2011b).

For example, high $\mathrm{Pb}$ concentration (up to $140 \mathrm{mg} \mathrm{kg}^{-1}$ ) was detected in remote site soils of Swiss National Park, situated far away from major industrial areas and traffic routes above sea level at an altitude of $2400 \mathrm{~m}$ (Bernd et al., 2001). Similarly, in Mendip region soils of Great Britain, high levels of $\mathrm{Pb}, \mathrm{Zn}$ and $\mathrm{Cd}$ were found because of high concentrations of these metals in bedrocks (Fuge et al., 1991). High As levels are reported in soils and waters of Bangladesh, Pakistan and India owing to presence of As-containing rocks in parent material of these areas (Shakoor et al., 2015, 2016).

\subsection{Anthropogenic sources}

Anthropogenic sources of soil contamination by heavy metal(loid)s include: refining and mining of ores, pesticides, batteries, paper industries, tanneries, fertilizer industries, solid wastes disposal including sewage sludge, wastewater irrigation and vehicular exhaust (Niazi et al., 2011, 2015; Shahid et al., 2015a). Generally, the metal(loid)s are released into the environment during processing and mining activities. Heavy metal(loid)s are released both in compound (inorganic and organic) and elemental forms. In some cases, metals emitted from these processes continue to build-up in the soil and other environmental compartments even long after these activities have ended. Peplow (1999) stated that mining of rigid rocks generally takes $5-15$ years for complete depletion of minerals, but soil contamination by metals persists for several years after termination of the mining processes. Similarly, Metaleurop located in north of France was one of the largest European smelter plants for $>100$ years (1884-2004). Dust particles emitted from this smelter have contaminated the nearby agricultural field with high contents of $\mathrm{Pb}, \mathrm{Zn}, \mathrm{Cd}$ and As surrounding an area of $40 \mathrm{~km}^{2}$ (Shahid et al., 2013a). Ross (1994) divided the anthropogenic sources of metal(loid)s contamination into five groups:

\author{
1. Agriculture (Zn, As, $\mathrm{Pb}, \mathrm{Cd}, \mathrm{Cu}$, selenium (Se) and uranium (U)) \\ 2. Metalliferous mining and smelting ( $\mathrm{Cd}, \mathrm{Pb}, \mathrm{As}$ and $\mathrm{Hg}$ ) \\ 3. Industry (Cd, $\mathrm{Hg}, \mathrm{As}, \mathrm{Cr}, \mathrm{Cu}, \mathrm{Co}, \mathrm{Ni}$ and $\mathrm{Zn}$ ) \\ 4. Waste disposal ( $\mathrm{As}, \mathrm{Pb}, \mathrm{Cu}, \mathrm{Cd}, \mathrm{Cr}, \mathrm{Zn}$ and $\mathrm{Hg}$ ) \\ 5. Atmospheric deposition ( $\mathrm{As}, \mathrm{Pb}, \mathrm{Cr}, \mathrm{Hg}, \mathrm{Cu}, \mathrm{Cd}$ and $\mathrm{U}$ )
}

\section{Soil heavy metal(loid)s pollution, food-chain contamination and human health}

Consumption of food contaminated with heavy metal(loid)s is considered to be the major pathway $(>90 \%)$ of human exposure compared to dermal contact or inhalation (Mombo et al., 2015; Xiong et al., 2016b). Soil is the direct path way for the contamination of heavy metal(loid)s in vegetables and crops via root uptake (Pierart et al., 2015). Vegetables and crops cultivated on heavy metal(loid)s polluted sites can take up heavy metal(loid)s (if pollutant bioavailability is high) greater than the maximum permissible limits (MPLs) and consequently may induce serious public health implications (Xiong et al., 2014). Increased accumulation of heavy metal(loid)s by vegetables higher than the MPLs has been reported in many parts of the world (Table 2). Excessive heavy metal(loid)s concentration in plant tissue is capable of inducing various physiological, morphological and biochemical toxic effects (Shahid et al., 2014a). Heavy metal(loid)s induce plant toxicity by disrupting nutrient and water uptake and transport, altering nitrogen metabolism, disrupting the activity of ATPase, reducing photosynthesis, interfering with plant growth, dysfunctioning plant photosynthetic machinery in chloroplasts and causing stomatal closure (Shahid et al., 2014b). Heavy metal(loid)s may also cause invisible symptoms of plant injury such as browning of roots, necrosis, chlorosis and leaf rolling (Pourrut et al., 2013). At the cellular level, excessive heavy metal(loid)s exposure can cause enhanced production of reactive oxygen species (ROS), alteration of cell cycles and division and chromosomal aberrations (Shahid et al., 2014a, 2015b).

Long-term use of heavy metal(loid)s contaminated vegetables/ crops can cause continuous buildup of toxic metals in the kidney and liver of humans causing disorders in the physico-biochemical processes (Jarup, 2003). Owing to their high persistence and nondegradable nature, heavy metal(loid)s have the potential of biomagnification and bioaccumulation, thus inducing more exposure for some organisms than their level in the environment. Heavy metal(loid)s are even capable to induce toxic effects to living organisms including human beings at very low levels due to the absence of proper defense mechanism to mitigate the toxic effects of these metals and to remove them from the body. Consumption of heavy metal(loid)s contaminated vegetables can cause depletion of nutrients in the human body that causes many problems in humans, intrauterine growth retardation, disabilities with malnutrition, impaired psycho-social faculties, upper gastrointestinal cancer and immunological defenses (Hediji et al., 2015). Heavy metal(loid)s can induce oxidative stress by overproduction of ROS, which can destroy cell's inherent defense system and can cause cell damage or death (Shahid et al., 2014a). Moreover, heavy metal(loid)s can substitute essential metals in enzymes, thus disrupting their functioning (Pourrut et al., 2011a, 2011b). Heavy metal(loid)s (Pb and $\mathrm{Cd}$ ) are capable to induce carcinogenesis, teratogenesis and mutagenesis; high $\mathrm{Pb}$ and $\mathrm{Cd}$ concentrations in edible plant parts were attributed to occurrence of upper gastrointestinal cancer (Jarup, 2003). Moreover, $\mathrm{Pb}$ is also reported to cause improper hemoglobin synthesis, renal and tumor infection, elevated blood pressure and dysfunctioning of reproductive system (Pourrut et al., 2011a, 2011b). Therefore, much attention is given worldwide to food safety and risk assessment. 
Table 2

Accumulation of heavy metal(loid)s in edible parts exceeding permissible limits of vegetables and crops when cultivated on heavy metal(loid)s polluted soils

\begin{tabular}{|c|c|c|c|c|c|c|}
\hline $\begin{array}{l}\text { Heavy } \\
\text { metals }\end{array}$ & Vegetables & $\begin{array}{l}\text { Concentration in soil } \\
(\mathrm{mg} / \mathrm{kg})\end{array}$ & $\begin{array}{l}\text { Concentration in plants edible parts } \\
(\mathrm{mg} / \mathrm{kg})\end{array}$ & $\begin{array}{l}{ }^{a} \text { Maximum allowable } \\
\text { limit }\end{array}$ & $\begin{array}{l}\text { Fold-higher than } \\
\text { allowable limit }\end{array}$ & References \\
\hline \multirow[t]{5}{*}{$\mathrm{Cd}$} & Lactuca sativa & 1.3 & 130 & 0.2 & 650 & Pereira et al., 2011 \\
\hline & $\begin{array}{l}\text { Solaum } \\
\text { lycopersicum }\end{array}$ & 11.24 & 13 & & 65 & Hediji et al., 2015 \\
\hline & Agaricus bisporus & - & 10 & & 50 & $\begin{array}{l}\text { Schlecht and Säumel, } \\
2015\end{array}$ \\
\hline & $\begin{array}{l}\text { Cynosurus } \\
\text { cristatus }\end{array}$ & 0.2 & 9.0 & & 45 & $\begin{array}{l}\text { Quezada-Hinojosa et al., } \\
2015\end{array}$ \\
\hline & Brassica napus & 1 & 6.0 & & 30 & Wu et al., 2015 \\
\hline \multirow[t]{5}{*}{$\mathrm{Pb}$} & Daucus carota & 0.01 & 390 & 1 & 390 & Carvalho et al., 2015 \\
\hline & $\begin{array}{l}\text { Solanum } \\
\text { aethiopicum }\end{array}$ & 452 & 144 & & 144 & Nabulo et al., 2012 \\
\hline & Brassica oleracea & 2.58 & 49 & & 49 & Perveen et al., 2012 \\
\hline & Lactuca sativa & - & 28 & & 28 & Kang et al., 2015 \\
\hline & Spinacia oleracea & 66.78 & 20 & & 20 & Khan et al., 2013 \\
\hline \multirow[t]{3}{*}{ As } & Nicotina glauca & 14,660 & 92 & 0.15 & 613 & $\begin{array}{l}\text { Santos-Jallath et al., } \\
2012\end{array}$ \\
\hline & Lactuca sativa & 5.83 & 14 & & 96 & Caporale et al., 2014 \\
\hline & Oryza sativa & - & 1.3 & & 8 & Smith et al., 2008 \\
\hline \multirow[t]{5}{*}{$\mathrm{Zn}$} & Nicotina glauca & 507 & 1985 & 50 & 40 & $\begin{array}{l}\text { Santos-Jallath et al., } \\
2012\end{array}$ \\
\hline & Brassica juncea & 190 & 201 & & 4.0 & Mapanda et al., 2007 \\
\hline & Zea mays & 80 & 148 & & 3.0 & Avci and Deveci, 2013 \\
\hline & Lactuca sativa & - & 118 & & 2.4 & $\begin{array}{l}\text { Bosiacki and Tyksiñski, } \\
2009\end{array}$ \\
\hline & Spinacia oleracea & 124 & 84 & & 1.7 & Naser et al., 2012 \\
\hline \multirow[t]{5}{*}{$\mathrm{Ni}$} & Lactuca sativa & 1.11 & 48 & 0.2 & 238 & Perveen et al., 2012 \\
\hline & $\begin{array}{l}\text { Solanum } \\
\text { lycopersicum }\end{array}$ & 1.11 & 43 & & 215 & Perveen et al., 2012 \\
\hline & Portulaca oleracea & - & 36 & & 181 & Renna et al., 2015 \\
\hline & $\begin{array}{l}\text { Diplotaxis } \\
\text { tenuifolia }\end{array}$ & - & 35 & & 175 & Renna et al., 2015 \\
\hline & $\begin{array}{l}\text { Cupressus } \\
\text { sempervirens }\end{array}$ & 11.3 & 7.0 & & 35 & $\begin{array}{l}\text { Farahat and Linderholm, } \\
2015\end{array}$ \\
\hline \multirow[t]{5}{*}{$\mathrm{Cu}$} & $\begin{array}{l}\text { Solanum } \\
\text { lycopersicum }\end{array}$ & - & 202 & 10 & 20 & Liu et al., 2006 \\
\hline & $\begin{array}{l}\text { Coriandrum } \\
\text { sativum }\end{array}$ & - & 48 & & 5 & Gupta et al., 2013 \\
\hline & Zea mays & 41 & 47 & & 5 & Avci and Deveci, 2013 \\
\hline & Agaricus bisporus & - & 36 & & 4 & Liu et al., 2015 \\
\hline & Apium graveolens & 46.85 & 11 & & 1 & Chao et al., 2007 \\
\hline \multirow[t]{5}{*}{$\mathrm{Cr}$} & $\begin{array}{l}\text { Solanum } \\
\text { aethiopicum }\end{array}$ & 256 & 65 & 1 & 65 & Nabulo et al., 2012 \\
\hline & Brassica oleracea & 12.78 & 24 & & 24 & Tiwari et al., 2011 \\
\hline & Capsicum & 1.11 & 17 & & 17 & Perveen et al., 2012 \\
\hline & Sinapis & 1.11 & 13 & & 13 & Perveen et al., 2012 \\
\hline & $\begin{array}{l}\text { Coriandrum } \\
\text { sativum }\end{array}$ & 1.11 & 13 & & 13 & Perveen et al., 2012 \\
\hline \multirow[t]{2}{*}{ Mn } & Allium cepa & 573 & 585 & 500 & 1.17 & Chiroma et al., 2014 \\
\hline & Lactuca sativa & 619 & 512 & & 1.02 & Chiroma et al., 2014 \\
\hline
\end{tabular}

a EU European Union Standards (2006); FAO WHO/FAO 2007.

\section{Remediation of heavy metal-contaminated soils}

Once metals are introduced into and contaminate the environment, they may persist for long time depending on the type of metal and soil. The remediation processes used for clean-up of heavy metal(loid)s contaminated sites may be in-situ or ex-situ, on-site or off-site, and biological, physical and chemical (Fig. 1). These techniques are often used in combination with each other for more economical and efficient remediation of a contaminated site.

\subsection{Physical remediation}

\subsubsection{Soil replacement}

Soil replacement of contaminated soil refers to replacing or partly replacing contaminated soil by non-contaminated soil. Prior to 1984 , excavation, off-site disposal and soil replacement were the most commonly method for cleaning-up contaminated sites. Soil replacement method dilutes the concentration of heavy metal(loid)s in soil, and in turns increases soil functionality (Yao et al., 2012). The replaced soil is generally treated to remove heavy metal(loid)s or in some cases dumped in other places. Soil replacement can also be carried out by (i) soil spading and (ii) new soil importing. In soil spading, contaminated site is dug deeply and the heavy metal(loid)s are spread into the deep sites, thus achieving the aim of metal diluting. New soil importing refers to adding clean soil into the heavy metal(loid) polluted soil. The added soil is either covered in the surface or mixed to make the metal concentration decreasing. Douay et al. (2008) carried out soil replacement remediation project in three kitchen gardens near Metaleurop Nord smelter situated in the North of France having high concentrations of $\mathrm{Pb}$ and $\mathrm{Cd}$ in the topsoils (up to 3300 and $24 \mathrm{mg} \mathrm{kg}^{-1}$ respectively). Under this study, they delineated a surface area of about $50-100 \mathrm{~m}^{2}$ for each garden, removed the contaminated soil and replaced it with a non-contaminated one. After soil replacement, cultivation of vegetables (during 2003 to 2005) showed a clear improvement of vegetables and soil quality (Douay et al., 2008). Soil replacement method can effectively isolate the contaminated soil and ecosystem, thus minimizing its effect on the environment. However, this technique is costly due to 
high labor work, and is appropriate for heavily contaminated soils with small area. Costs for bulk excavation, transportation over short distance, and disposal vary from $\$ 270$ to $\$ 460$ per ton. Costs for long distance transport of excavated soil may be substantially higher. Moreover, this technique may not be applicable to agricultural sites because there is a risk of loss of soil fertility.

\subsubsection{Soil isolation}

Soil isolation means to separate the heavy metal(loid) contaminated soil from the uncontaminated soil, but for complete remediation it still needs other auxiliary engineering measures (Zheng and Wang, 2002). Isolation technologies are generally designed to prevent off-site movement of heavy metal(loid)s and other contaminants by restricting them within a specified area (Zhu et al., 2012). Soil isolation technology is used to avoid further contamination of groundwater by heavy metal(loid)s when other remediation methods are not economically or physically feasible. In some cases, contaminated sites are isolated temporarily in order to avoid transport during site assessment and remediation.

Subsurface barriers are commonly used to separate contaminated water and soil by restricting the flow of ground and/or surface water at a contaminated site. Subsurface barriers restrict the flow of contaminated groundwater through the uncontaminated site as well as the flow of uncontaminated groundwater from the contaminated site (Rumer and Ryan, 1995). Vertical subsurface barriers restrict the lateral movement of groundwater. These vertical barriers can be installed downstream, upstream, or completely surrounding the site. Vertical barriers are often installed in combination with a capping system to restrict infiltration of uncontaminated surface water. These barriers cannot be installed to deep soil and are often limited to around $30 \mathrm{ft}$. In order to effectively isolate the contaminated part of soil, the barrier should be continuous with low-permeability layer. This is mostly achieved by establishing a layer of low-permeable material such as clay below the contaminated region of soil (Rumer and Ryan, 1995). Various materials are used for sub-surface barriers, which include sheet piles, grout curtains and slurry walls.

\subsubsection{Vitrification}

The mobility of heavy metal(loid)s inside soil can be reduced by applying high temperature treatment at the contaminated site (Mallampati et al., 2015) that leads to the formation of vitreous material. During vitrification, some metal species (such as $\mathrm{Hg}$ ) may be volatilized under high temperature that must be collected for further disposal or treatment. Vitrification is not considered a classical metal remediation technique. Vitrification is comparatively easy to apply compared to other physical remediation methods. Vitrification can be applied to majority of soils contaminated with inorganic (heavy metal(loid)s) and organic contaminants. During in situ vitrification, electric current is passed through the soil by vertically inserting an array of electrodes into the contaminated area. However, dry soil may not provide enough conductance for vitrification. Recently, Dellisanti (2016) carried out an in-field Joule heating vitrification of tons of $\mathrm{Zn}$ and $\mathrm{Pb}$ rich ceramic waste by heating up to about $1850^{\circ} \mathrm{C}$. They reported that the vitrification method was greatly efficient to clean-up tons of heavy metal(loid)s contaminated waste materials and can be applied for cleaning huge volumes of soil. Temperature during vitrification plays a key role in the immobilization of heavy metal(loid)s in soil samples. For example, Navarro et al. (2013) carried out vitrification of waste from Ag-Pb mines in Spain using solar technology. They showed that vitrification caused immobilization of $\mathrm{Zn}, \mathrm{Mn}, \mathrm{Fe}, \mathrm{Cu}$ and $\mathrm{Ni}$ at $1350{ }^{\circ} \mathrm{C}$, whereas $\mathrm{Zn}, \mathrm{Ni}, \mathrm{Mn}$ and $\mathrm{Cu}$ were mobilized at $1050^{\circ} \mathrm{C}$.

Vitrification can be performed both in situ and ex situ, although in situ method is preferred due to comparatively low cost and energy requirements. Ex situ vitrification processes contains various stages such as excavation, mixing, pretreatment, melting feeding, and casting of the melted product (Dellisanti, 2016). Ex situ vitrification requires high energy for melting, and is therefore costly. In some cases, the vitrified material is mixed with additives such as clay, native soil or sand to prepare a product with certain characteristics, which may improve the effectiveness of this technology. The vitrified material can be recycled and used as reusable materials, aggregate and clean fill (Smith et al., 1995). The main limitation of in situ vitrification is the potential of the soil to melt so that current can pass through it. Moreover, soil having high alkali content (1.4 wt\%) may not be good conductor of current (Buelt and Thompson, 1992). Therefore, in situ vitrification can be performed only under wet soil with low alkali content. This technique can be applied for small scale remediation of heavy metal(loid) polluted sites. Under field conditions or at large scale, this technique can be highly expensive.

\subsubsection{Electrokinetic remediation}

Soil electrokinetic remediation is a new and cost effective physical method for the remediation of heavy metal(loid)s. Soil electrokinetic remediation operates on the principle that the electric field gradient of suitable intensity is established on two sides of the electrolytic tank containing saturated contaminated soil. Heavy metal(loid)s present in the soil are separated via electrophoresis, electric seepage or electro-migration, and thus decrease the contamination (Yao et al., 2012). Rosestolato et al. (2015) remediated approximately $400 \mathrm{~kg}$ of soil using electrokinetic remediation and removed about $60 \%$ of total $\mathrm{Hg}$ from contaminated soil in $<3$ months. Electrokinetic remediation method is also used in combination with other techniques/processes such as electrokineticmicrobe joint remediation (Yu et al., 2009), electrokinetic-chemical joint remediation (Vocciante et al., 2016), electrokinetic-oxidation/reduction joint remediation (Yang et al., 2015), coupled electrokinetic phytoremediation (Mao et al., 2016), electrokinetics coupled with electrospun polyacrylonitrile nanofiber membrane (Peng et al., 2015), and electrokinetic remediation conjugated with permeable reactive barrier (Rosestolato et al., 2015).

The removal of heavy metal(loid)s having poor conductivity (e.g. sulfides) or present in metallic form (e.g. $\mathrm{Hg}$ ) requires preliminary dissolution. In such cases, use of an appropriate electrolyte (distilled water, organic acids or synthetic chelates) may increase removal efficiency of electrokinetic remediation method (Iannelli et al., 2015). However, the removal efficiency varies with the type of chemical used (anolyte) and metal remediated (Vocciante et al., 2016). For example, Lee et al. (2016) used $\mathrm{KH}_{2} \mathrm{PO}_{4}$ as an anolyte and showed that removal efficiencies increased by $>50 \%$ for As species and $\sim 20 \%$ for Cu species. However, removal of the $\mathrm{Pb}$ and $\mathrm{Zn}$ was relatively inefficient $(<20 \%)$. Rozas and Castellote (2012) analysed the effectiveness of different experimental variables (type of electrolyte, applied level, constants of precipitation (pKs) and chelation equilibriums $(\log \beta)$, initial and final $\mathrm{pH}$ of the catholyte and anolyte, and zeta potential) for different electrolyte solutions (distilled water, humic acid, acetic acid, citric acid and ethylene diamine tetraacetic acid (EDTA)). They reported that the zeta potential, $\mathrm{pH}$ of the cathodic solution and quelation ability influence the efficiency of electrokinetic remediation. Suzuki et al. (2014) also reported enhanced $\mathrm{Pb}$ and $\mathrm{Cd}$ remediation efficiencies by adding ethylene diamine disuccinate (EDDS). Mao et al. (2016) used coupled electrokinetic phytoremediation and showed that electro-kinetic field lowered soil $\mathrm{pH}$ to around 1.5 and enhanced dissolution of $\mathrm{Pb}$, As and $\mathrm{Cs}$, thus increasing their overall solubility and bioavailability.

However, electrokinetic remediation method operates well for soils having low permeability (Hanson et al., 1992). Electrokinetic remediation method is economically effective because it is easy to install and operate (Virkutyte et al., 2002), moreover, electrokinetic remediation does not abolish the original nature of the soil (Page and Page, 2002). However, the main limiting factor for direct electrokinetic remediation is fluctuation in soil $\mathrm{pH}$ because it cannot maintain soil $\mathrm{pH}$ value. In some cases, soil pH is controlled by adding buffer solutions in cathode and anode, using complexant or ion exchange membrane (Wang et al., 2007). 


\subsection{Chemical remediation}

\subsubsection{Immobilization techniques}

Immobilization refers to decrease in metal mobility, bioavailability and bioaccessibility of heavy metal(loid)s in soil by adding immobilizing agents to the contaminated soils. Heavy metal(loid)s can be immobilized in soil by complexation, precipitation and adsorption reactions. These processes cause redistribution of heavy metal(loid)s from soil solution to solid particles, thus limiting their transport and bioavailability in soil. Heavy metal(loid)s immobilization in soil is generally carried out by using organic and inorganic amendment to soils (Shahid et al., 2014c; Austruy et al., 2014; Ashraf et al., 2016). The most commonly amendments include cement, clay, zeolites, phosphates, minerals, microbes and organic amendments (Sun et al., 2016). Recent research also highlighted the potential of low-cost industrial residues such as termitaria (Anoduadi et al., 2009), industrial eggshell (Soares et al., 2015) and red mud (Smičiklas et al., 2014) for immobilization of heavy metal(loid)s in contaminated soils.

It is well known that the organic amendments can immobilize heavy metal(loid)s in soil through adsorption reactions or forming stable complexes (Shahid et al., 2014d; Sabir et al., 2015). Over time, effect of organic amendments on bioavailability of metals varies due to decomposition of organic matter. However, the immobilizing effect of organic amendments on heavy metal(loid)s at the initial stage of their application is important for remediation of contaminated sites. The major organic amendments used for heavy metal(loid)s immobilization include animal manures and biosolids. Biosolids, treated and stabilized solid organic residual by-products, generally contain heavy metal(loid)s, although advances in the sewage and wastewater treatment technologies are successfully reducing heavy metal(loid)s level in biosolids. Several studies have reported the negative effect of biosolid application as a source of heavy metal(loid)s contamination in the soil (Cele and Maboeta, 2016); however, some studies have reported the advantageous impact of organic amendments as adsorbent for stabilization of heavy metal(loid)s in the soil (Venegas et al., 2015; Shakoor et al., 2015).

Manure byproducts containing low levels of metal(loid) are nowadays used for metal immobilization in soils (Venegas et al., 2015). Khan et al. (2015) reported that the use of farm yard manure (FYM) was highly effective in immobilizing $\mathrm{Fe}, \mathrm{Cr}, \mathrm{Ni}, \mathrm{Mn}$, and $\mathrm{Pb}$, while di-ammonium phosphate (DAP) was more effective for stabilizing $\mathrm{Cu}, \mathrm{Cd}$, and $\mathrm{Zn}$ in soil. Organic amendments usually increase organic contents of soil (Bolan et al., 2014). Organic amendments usually contain cellulose and lignin as the main constituents. Other components are extractives, hemicellulose, proteins, lipids, starches, simple sugars, hydrocarbons, and many other compounds that contain a number of functional groups such as carbonyl, phenolic, acetamido groups, amido, amino, structural polysaccharides and esters (Niazi et al., 2016a) having high affinity for metal complexation. Metals are known to form complexes (both soluble and insoluble) with organic component in soils (Shahid et al., 2014e). Formation of metal-organic matter complexes apparently depends on the type and nature of the organic matter (Shahid et al., 2014e). Organic constituents of soil have a high affinity for metal(loid)s due to high binding constants of metal ions with phenolic hydroxyl and carboxylic (COOH) groups of dissolved organic matter (Shahid et al., 2012a). Immobilization of heavy metal(loid)s by organic amendments can be due to increase in soil $\mathrm{pH}$ by preventing sulfide oxidation/hydrolysis (Walker et al., 2004). In addition to formation of stable complexes with metal ions, organic amendments can reduce metal bioavailability by increasing in surface charge (Gadd, 2000).

Biomaterials have been greatly used in recent years to immobilize heavy metal(loid)s in soil due to their easy availability and low-cost. Among biomaterials, the use of biochar has received significant attention to immobilize heavy metal(loid)s in soil. Biochar is a carbon rich, porous, purpose-produced charcoal manufactured during the pyrolysis of organic residues such as municipal waste, animal wastes, wood, crop residues, and biosolids. Several studies revealed that addition of biochars to soil greatly enhanced the sorption of heavy metal(loid)s and significantly reduced their mobility and phytoavailability (Al-Wabel et al., 2015; Puga et al., 2015). Addition of biochar to soil changes chemical, physical, and biological properties of soil. Changes in the soil properties especially increase of $\mathrm{pH}$ can cause their precipitation and thereby heavy metals immobilization in soils.

\subsubsection{Encapsulation}

Among the remedial approaches, immobilization of toxic metal solutions is an effective method to reduce hazardous material and their subsequent safe disposal as a landfill by encapsulating them in manageable solid blocks (Ucaroglu and Talinli, 2012). Encapsulation involves the mixing of the contaminated soils with other products, such as concrete, lime, or asphalt. The contaminated soil becomes immobile and thus prevents contamination of the surrounding materials. A number of binding materials are used in solid blocks formation but cement is preferred because of its easy availability, versatility, and cost-effectiveness (Pandey et al., 2012). Ordinary Portland Cement (OPC) has been commonly used as a good metal retainer, and in the last few years, alternative binders are receiving growing attention. For instance, encapsulation of hazardous materials with calcium aluminate cement (CAC) has been examined to be highly efficient and effective (Navarro et al., 2013). A variant of a CAC matrix is phosphate-bonded CAC, which is found by acidbase reaction between acidic phosphate solutions and CAC as the base reactant (Sugama and Carciello, 1995). These phosphate amended CAC have been applied and investigated as potential cementing materials for encapsulation of radioactive wastes (Swift et al., 2013) and to prevent the aluminum containing nuclear wastes from corrosion (Kinoshita et al., 2013).

The leaching of organic materials may be prevented effectively by encapsulation (He and Chen, 2014). In encapsulation, various immobilization agents, e.g., polyvinylalcohol, chitosan, alginate, agar, polyacrylamide and polyurethanes are used. However, encapsulation by lime and concrete has been used simultaneously in the effective treatment of oil contaminated and heavy metal(loid)s soil, whereas asphalt encapsulation used for hydrocarbons contaminated soils. The major drawback of these methods is an instant market for the final product, otherwise the end result will be random patches of asphalt and concrete (Mulligan et al., 2001). This limitation has led to the development of a silica based encapsulation remediation technology. The presence of different carboxylic groups in Algin make it an excellent encapsulating agent as well as an efficient sorbent for metal ions (Kuang et al., 2015). These reactive groups may interact with metal cations via chelation, and also contribute in gelling biopolymer. Algin encapsulated polyethylenimine (PEI)-derivatives microparticles were tested for recovering Cd(II), Zn(II), and $\mathrm{Cu}(\mathrm{II})$ ions from simple and complex synthetic solutions (Bertagnolli et al., 2016).

Metallic nanoparticles (NPs) of Fe (Park et al., 2000), Co (Tripp et al., 2002) and $\mathrm{Ni}$ (Hou and Gao, 2003) are of great interest due to their unusual magnetic, optical, and electrochemical properties (Hou and Gao, 2003) as well as chemical catalytic activities (Sun and Xia, 2002) resulting from their fine size and high specific surface area (Rashid et al., 2016). Carbon-encapsulated magnetic NPs were justified as a promising candidate for efficient removal of heavy metal(loid) from wastewater (Zhang et al., 2010). Sun et al. (2006) have reported the removal of methyl orange by carbon-encapsulated magnetic NPs. Application of encapsulated nanoparticles for removal of heavy metal is very limited. Magnetic NPs with regular shape and narrow size distribution are necessary to maintain the dispersion stability of NPs in the wastewater. Additionally, introduction of external magnetic fields will greatly enhance mobility of magnetic NPs, thereby facilitating recycling of NPs used for treatment of waste water containing toxic heavy metal(loid)s (Zhang et al., 2010). 


\subsubsection{Soil washing}

Soil washing refers to removal of heavy metal(loid)s from soil using various reagents and extractants (Guo et al., 2016; Park and Son, 2016) that can leach the heavy metal(loid)s from the soil. Recently, use of suitable extractants for leaching heavy metal(loid)s from contaminated soils have proven as an alternate to some of the conventional techniques for the clean-up of contaminated soils. During soil washing, the contaminated soil is dug out and mixed with a suitable extractant solution depending on the type of metal and soil. The extractant solution and soil are mixed thoroughly for a specified time. Through the precipitation, ions exchange, chelation or adsorption, the heavy metal(loid)s in soil are transferred from soil to liquid phase, and then separated from the leachate (Ferraro et al., 2015). The separated soil that fulfills regulatory criteria can be backfilled to original site. Use of soil washing for the remediation of heavy metal(loid) contaminated sites is frequently used because it completely removes the metals from soil. Moreover, soil washing is a rapid method which can meets specific criteria without any long-term liability (Park and Son, 2016). Owing to its high efficiency, soil washing is considered one of the most cost-effective soil remediation technologies.

A number of reagents have been used to mobilize and remove heavy metal(loid)s from soil including synthetic chelating agents (EDTA, EDDS), organic acids, humic substances, surfactants and cyclodextrins (Shahid et al., 2014a; Kulikowska et al., 2015). These reagents used for soil washing have been established on a case-by-case basis and their application and efficiency vary with the type of heavy metal(loid) and site. It is well-known that the exchange/extraction/solubilization of heavy metal(loid)s during soil washing depend on soil and metal type (Liao et al., 2015). The efficiency of soil washing depends on the ability of extractant to dissolve the heavy metal(loid)s in soils. Therefore, extractants which can dissolve high levels of metals would be appropriate for soil cleaning. Among the extractants, synthetic chelates such as EDTA and EDDS are considered the most effective and suitable for soil washing because these chelates can form stable complexes with most of the heavy metal(loid)s in the wide pH range (Saifullah et al., 2015). For the removal of cationic metals, EDTA is known as the most effective synthetic chelating agent but not in the anionic metals (Udovic and Lestan, 2010).

Other soil washing chemicals include high concentration salt chloride solution such as iron (III) chloride and calcium chloride (Makino et al., 2008). Makino et al. (2006) stated that $\mathrm{FeCl}_{3}$ was highly effective for soil washing of $\mathrm{Cd}$ contaminated paddy soils because of cost effectiveness, its Cd extraction efficiency and lower environmental impact. Rinsing steps and repeated washing are conducted to improve the removal efficiency of heavy metal(loid)s which can reduce the consumption of washing agents and the washing costs (Torres et al., 2012). Similarly, combined use of different chelators also improves heavy metal(loid)s washing efficiency especially for multi-metal contaminated soils (Guo et al., 2016). Some authors used more than one washing chelators for sequential extraction/washing of heavy metal(loid)s contaminated soil. For example, Wei et al. (2016) reported that phosphoric-oxalic acid- $\mathrm{Na}_{2}$ EDTA order based soil washing enhanced heavy metal(loid)s removal efficiency by $41.9 \%$ for As and $89.6 \%$ for $\mathrm{Cd}$.

\subsection{Biological remediation}

Bioremediation is one of the most viable options to rectify and re-establish the natural condition of soil considered detrimental to environmental health. Bioremediation makes use of microorganisms/plants to detoxify or remove heavy metal(loid)s from the soil. Bioremediation is cost-effective, non-invasive and provides a permanent solution.

\subsubsection{Phytoremediation}

Phytoremediation, also known as botanoremediation, vegetative remediation, green remediation or agroremediation, comprises technologies that make use of plants to remediate and revegetate contaminated sites. The concept of using metal-accumulating plants to clean up heavy metal(loid)s contaminated sites was first presented in 1983, but the practice of cleaning soil by plants has been executed for the last 300 years. Phytoremediation is considered environmental friendly, attractive, aesthetically pleasing, non-invasive, energy efficient, and cost-effective technology to clean up the sites with low-to-moderate levels of heavy metal(loid)s (Sabir et al., 2015). Phytoremediation can be used effectively in combination with several other traditional remediation techniques as a finishing step to the remedial process. The efficiency of phytoremediation depends on numerous plant and soil factors such as the physico-chemical properties of the soil, bioavailability of metals in soil, microbial and plant exudates, and the capacity of living organisms to uptake, accumulate, sequester, translocate and detoxify metals. The term phytoremediation includes several techniques and applications which differ greatly in the process/mechanism by which plants can immobilize, remove, or degrade metals. Phytoremediation is generally categorized into phytostabilization, phytoevaporation and phytoextraction are based on different uptake mechanisms.

5.3.1.1. Phytovolatilization. During phytovolatilization, heavy metal(loid)s are taken up from the soil and converted into less toxic vapours, which are then released into the atmosphere through transpiration process of the plants. In phytovolatilization, metals are assimilated into volatile organic compounds which are then released into atmosphere as biomolecules (Marques et al., 2009). Some heavy metal(loid)s such as $\mathrm{Se}, \mathrm{Hg}$ and As may exist as gaseous species in the environment. Some plant species such as Arabidopsis thaliana, Brassica juncea and Chara canescens are capable to uptake heavy metal(loid)s and transfer them to gaseous species inside the plant followed by their release into the atmosphere (Verbruggen et al., 2009). Arsenic was effectively volatilized in the form of As compounds (arsenite and arsenate) in the frond of Pteris vittata (Sakakibara et al., 2010). Phytovolatilization has been used mainly for removing $\mathrm{Hg}$ by converting it into gaseous $\mathrm{Hg}$, which is the comparatively less toxic (Ghosh and Singh, 2005). Brassica juncea and Arabidopsis thaliana can grow under high Se level and are capable to volatilize Se. Plant-induced volatilization of Se includes conversion of inorganic Se into the organic selenomethionine and selenoaminoacids selenocysteine followed by biomethylated to form dimethylselenide or dimethyldiselenide, which are volatile and can be secreted to the atmosphere (Bañuelos and Mayland, 2000).

Conversion of heavy metal(loid)s into gaseous/volatilized form inside the plants is via specific mechanisms, which are generally governed inside plants by some specific enzymes or genes. There are very less number of naturally occurring plants capable of converting metals into volatilize form. Phytovolatilization technique therefore generally makes use of genetically modified plants to enhance ability of plants to volatilize metals. Arabidopsis thaliana and N. tabacum have been genetically engineered (Meagher, 2000) with mercuric reductase, a gene which can volatilize $\mathrm{Hg}$ (Meagher, 2000). In order to enhance $\mathrm{Hg}$ phytovolatilization by plants, $\mathrm{Hg}$ reductase genes has been inserted from bacterial into plants (Rugh et al., 1998). Transgenic plants genetically engineered with bacterial genes (merA and merB) can volatilize almost 100-1000 times more Hg than wild-type plants (Rugh et al., 1996).

A gene which can encode sterol methyl transferases (SMT) enzyme was introduced into Arabidopsis and Brassica juncea from Astragulus bisculatus (Neuhieral et al., 1999). Over expression of SMT enzyme in Brassica juncea and Arabidopsis enhanced Se accumulation, tolerance and volatilization (Neuhieral et al., 1999). It is reported that volatile Se compounds (dimethylselenide) are almost 500-600 fold less toxic compared to inorganic Se forms usually present in the soil (Deesouza et al., 2000). Cystathionine Gamma-Synthase (CGS) is an enzyme that is reported to play a key role in heavy metal(loid) volatilization. Enhanced production of CGS in transgenic Brassica enhanced volatilization of Se, and the CGS transgenic plants were more tolerant to selenite than 
wild type (Van Huysen et al., 2003). The transgenic Brassica overexpressing CGS contained 50-70\% lower Se level in roots and 20-40\% lower in shoots than in wild type (Van Huysen et al., 2003). Encoding and expression of As(III)-S-adenosylmethionine methyltransferase (arsM) gene in an As-sensitive strain of E. coli resulted in the biosynthesis of several volatilized forms of As (Qin et al., 2006).

However, the practical application of heavy metal(loid)s phytovolatilization for soil remediation seems questionable. This is because, in phytovolatilization, once the metal has been volatilized, no one has control over its fate in the atmosphere. Some studies reported that after being released into atmosphere, volatile compounds are diluted and dispersed in the atmosphere and thus induce very minute or no environmental hazard (Meagher, 2000). Moreover, phytovolatilization involves little erosion and no disposal of contaminated plant biomass with negligible site disturbance (Rugh et al., 2000).

5.3.1.2. Phytostabilization. Phytostabilization is the use of plants to decrease the bioavailability and mobility of heavy metal(loid)s in soils due to their stabilization with the help of plants (Sylvain et al., 2016). Phytostabilization of metals does not reduce the concentration of heavy metal(loid)s present in contaminated soil but prohibits their off-site movement. Phytostabilization aims to restrict heavy metal(loid)s in the vadose zone of plants through accumulation by roots or precipitation within the rhizosphere (Bolan et al., 2011). Therefore, unlike other methods of phytoremediation, phytostabilization does not remediate the contaminated soils but reduces the contamination of nearby media/area. Phytostabilization is generally used for soils where phytoextraction is not desirable or possible. Furthermore, phytostabilization can also be used at sites where technical or regulatory limitations interrupt with the selection and implementation of the most appropriate remediation techniques. For example, in order to limit off-site heavy metal(loid)s movement from barren contaminated site, phytostabilization can be a useful option. Plants can prohibit movement of metals through several methods: reduced leaching through upward water flow generated by plant transpiration, reduced soil erosion due to stabilization of soil by plant roots and decrease in runoff due to above-ground vegetation. Phytostabilization does not produce contaminated secondary waste that needs further management. Phytostabilization is helpful in achieving ecosystem restoration because it increases soil fertility. However, since the heavy metal(loid)s are stabilized within soil, the site needs regular monitoring to make sure that the optimal stabilizing conditions are retained (Bolan et al., 2011). Phytostabilization may raise some issues under highly contaminated soils. In such cases, cultivation of plant species tolerant to metal contamination and adapted to the local environmental conditions is advantageous.

Metal excluder plants accumulate high levels of heavy metal(loid)s from soil into their roots with limited transport to their aerial parts (Ali et al., 2013). These plants have a little potential for metal extraction but are highly efficient for phytostabilization purposes (Ali et al., 2013). Among the hyperaccumulator plants, the most effective for phytostabilization are able to (i) restrict heavy metal(loid) leaching by reducing water percolation through the soil matrix, (ii) inhibit soil erosion and movement of heavy metal(loid)s to other areas and (iii) prevent direct contact with heavy metal(loid) contaminated soil (Bolan et al., 2011). Plants generally cause heavy metal(loid)s immobilization in polluted soils by inducing changes in their rhizosphere, which has discrete physico-bio-chemical conditions (Abbas et al., 2016). For example, Cd forms complexes with sulfide (de Knecht et al., 1994) and $\mathrm{Pb}$ is precipitated as phosphate (Cotter-Howells and Caporn, 1996) in the root zone of Silene vulgaris and Agrostis capillaris, respectively. During last 23 decades, numerous plant species, especially the agricultural grasses have been effectively used in phytostabilization. Willows (Salix spp.) are considered ideal plants for both phytoextraction and phytostabilization owing to their elevated tolerance to heavy metal(loid)s, high territorial expansion and intense evapotranspiration (Sylvain et al., 2016). Some plant species such as Festuca spp. and Agrostis spp. are most commonly used for phytostabilization of $\mathrm{Pb}, \mathrm{Zn}$ and $\mathrm{Cu}$ polluted soils in Europe (Galende et al., 2014).

Phytostabilization can also be used in combination with other remediation approaches such as use of soil microorganisms and organic amendments to enhance heavy metal(loid)s immobilization in soil. Soil microorganisms are reported to increase root metal contents via increased growth as well as the heavy metal(loid)s immobilization in soil (Rajkumar et al., 2013). Moreover, addition of compost significantly enhances microbial diversity via long-lasting buffering-effect on $\mathrm{pH}$, and consequently allowing plants to germinate and accumulate more heavy metal(loid)s in roots (Valentín-Vargas et al., 2014). Organic and inorganic amendments (natural and synthetic) also facilitate plant-induced immobilization of heavy metal(loid)s in soil (Parra et al., 2016). Lee et al. (2014) evaluated the effect of four different amendments (furnace slag, bottom ash, bone mill, and red mud) as immobilizing agents in conjugation with Miscanthus sinensis and Pteridium aquilinum in aided phytostabilization of heavy metal(loid)s contaminated soil. Application of amendments significantly reduced soluble and extractable heavy metal(loid)s fractions (up to 99\%) in soil in the presence of Pteridium aquilinum and Miscanthus sinensis. The phytostabilized sites require continuous monitoring to make sure that the stabilizing condition is sustained. Soil amendment used to reduce heavy metal(loid)s mobility in soil may need to be occasionally reapplied to retain immobilizing conditions (Bolan et al., 2011).

5.3.1.3. Phytoextraction. Phytoextraction involves clean-up of heavy metal(loid)s from soil by means of plant uptake. This solar-driven technique is based on the capability of the plant roots to uptake, translocate, and concentrate heavy metal(loid)s from soil to the aboveground harvestable plant parts. In this way, phytoextraction results in the decrease of contaminated mass (soil). During phytoextraction, heavy metal(loid)s are transferred from soil to plant biomass. Plant biomass is comparatively very easy to recycle, dispose, treat or oxidize compared to soil. Phytoextraction guarantees a permanent removal of metal(loid)s from the contaminated sites. However, phytoextraction is suitable to those sites which are polluted by low-moderate levels of metals, because most plant species are not able to sustain in heavily polluted sites (Rascio and Navari-Izzo, 2011; Sabir et al., 2015). For example, phytoextraction technique can be used for $\mathrm{Pb}$ remediation by Brassica juncea for sites whose $\mathrm{Pb}$ level is $<1500 \mathrm{mg} / \mathrm{kg}$ (Blaylock and Huang, 2000).

Hyperaccumulators are plants species capable to accumulate heavy metal(loid)s in their shoot tissues (without visible toxicity symptoms) to levels far above those present in the soil or in non-accumulating plant species (Arshad et al., 2008; Shahid et al., 2012b; Ali et al., 2013). Plant species which can be effectively used for phytoextraction must have (i) high metal-accumulation capability in their above ground parts, (ii) tolerance to high concentration of metals, (iii) ability to grow fast with high biomass and (iv) profuse root system. There are no defined standards for hyperaccumulator plants. However, different researchers or research groups have defined hyperaccumulators. Brooks et al. (1977) were the first to use the term "hyperaccumulator" for plants which can accumulate $\mathrm{Ni}>1000 \mathrm{mg} \mathrm{kg}^{-1}$ dry weigh (0.1\%). Hyperaccumulator plant species are capable to accumulate 100-500 fold higher metals in shoots with no effect on the yield as compared common nonaccumulator plants (Bhargava et al., 2012; Mahar et al., 2016; Sheoran et al., 2016). Storage and accumulation requirements of hyperaccumulator plant species are different for different metals. Plant species which accumulate $>100 \mathrm{mg} / \mathrm{kg} \mathrm{Cd}$ and Se (on dry weight basis), $>1000 \mathrm{mg} / \mathrm{kg} \mathrm{Cu}, \mathrm{Ni}, \mathrm{As}$, and $\mathrm{Pb}$ or $>10,000 \mathrm{mg} / \mathrm{kg} \mathrm{Mn}$ and $\mathrm{Zn}$ in their aerial plant parts when grown on heavy metal(loid) contaminated soils are called hyperaccumulator plants (Mahar et al., 2016). According to Verbruggen et al. (2009), concentration criterion (\% in leaf dry matter) for hyperaccumulator plants is $\mathrm{Cd} \geq 0.01, \mathrm{~Pb} \geq 0.1$, 
Table 3

Some examples of hyperaccumulator plants accumulating high levels of heavy metal(loid)s in their above ground parts.

\begin{tabular}{|c|c|c|c|c|c|c|}
\hline Vegetables & $\begin{array}{l}\text { Heavy } \\
\text { metals }\end{array}$ & $\begin{array}{l}\text { Concentration in plant aerial } \\
\text { parts }(\mathrm{mg} / \mathrm{kg})\end{array}$ & $\begin{array}{l}\text { Threshold level for } \\
\text { hyper-accumulator }\end{array}$ & Type of remediation & $\begin{array}{l}\text { Fold-higher than } \\
\text { threshold level }\end{array}$ & Reference \\
\hline Prosopis laevigata & $\mathrm{Cd}$ & 8176 & 100 & Phytoextraction & 81.8 & $\begin{array}{l}\text { Buendía-González et al., } \\
2010\end{array}$ \\
\hline Arabidopsis halleri & & 5722 & & Phytoextraction & 57.2 & Küpper et al., 2000 \\
\hline $\begin{array}{l}\text { Thlaspi } \\
\text { caerulescens }\end{array}$ & & 5000 & & Phytoextraction & 50.0 & Koptsik, 2014 \\
\hline $\begin{array}{l}\text { Thlaspi } \\
\quad \text { caerulescens }\end{array}$ & & 3000 & & Phytoextraction & 30.0 & Sheoran et al., 2009 \\
\hline Viola principis & & 1201 & & Phytoextraction & 12.0 & Wan et al., 2016 \\
\hline Potentilla griffithii & & 852 & & Phytoextraction & 8.5 & Hu et al., 2009 \\
\hline Solanum nigrum & & 387 & & Phytoextraction & 3.9 & Sun et al., 2008 \\
\hline Lonicera japonica & & 286 & & Phytoextraction & 2.9 & Liu et al., 2009 \\
\hline $\begin{array}{l}\text { Thlaspi } \\
\text { caerulescens }\end{array}$ & & 263 & & Phytoextraction & 2.6 & Lombi et al., 2001 \\
\hline $\begin{array}{l}\text { Eleocharis } \\
\text { acicularis }\end{array}$ & & 239 & & Phytoextraction & 2.4 & Sakakibara et al., 2011 \\
\hline $\begin{array}{l}\text { Deschampsia } \\
\text { cespitosa }\end{array}$ & & 236 & & Phytoextraction & 2.4 & Kucharski et al., 2005 \\
\hline $\begin{array}{l}\text { Solanum } \\
\quad \text { photeinocarpum }\end{array}$ & & 158 & & Phytoextraction & 1.6 & Zhang et al., 2011 \\
\hline $\begin{array}{l}\text { Phyllanthus } \\
\text { serpentinus }\end{array}$ & $\mathrm{Ni}$ & 38,100 & 1000 & Phytoextraction & 38.1 & Chaney et al., 2010 \\
\hline Alyssum murale & & 22,800 & & Phytoextraction & 22.8 & Chaney et al., 2008 \\
\hline Alyssum corsicum & & 18,100 & & Phytoextraction & 18.1 & Li et al., 2003 \\
\hline Berkheya coddii & & 18,000 & & Phytoextraction & 18.0 & $\begin{array}{l}\text { Mesjasz-Przybyłowics et } \\
\text { al., } 2004\end{array}$ \\
\hline $\begin{array}{l}\text { Thlaspi } \\
\quad \text { caerulescens }\end{array}$ & & 16,200 & & Phytoextraction & 16.2 & Koptsik, 2014 \\
\hline Salvinia minima & & 16,600 & & Phytoextraction & 16.6 & Fuentes et al., 2014 \\
\hline Alyssum murale & & 15,000 & & Phytoextraction & 15.0 & Li et al., 2003 \\
\hline $\begin{array}{l}\text { Alyssum } \\
\text { serpyllifolium }\end{array}$ & & 10,000 & & Phytoextraction & 10.0 & Prasad, 2005 \\
\hline Isatis pinnatiloba & & 1441 & & Phytoextraction & 1.4 & Altinozlu et al., 2012 \\
\hline $\begin{array}{l}\text { Arrhenatherum } \\
\text { elatius }\end{array}$ & $\mathrm{Pb}$ & 24,000 & 1000 & Phytoextraction & 24.0 & Deram et al., 2000 \\
\hline Brassica juncea & & 10,300 & & Phytoextraction & 10.3 & Koptsik, 2014 \\
\hline Brassica nigra & & 9400 & & Phytoextraction & 9.4 & Koptsik, 2014 \\
\hline $\begin{array}{l}\text { Pelargonium } \\
\text { (Atomic) }\end{array}$ & & 7000 & & Phytoextraction & 7.0 & Arshad et al., 2008 \\
\hline Helianthus annuus & & 5600 & & Phytoextraction & 5.6 & Koptsik, 2014 \\
\hline $\begin{array}{l}\text { Pelargonium } \\
\text { (Clorinda) }\end{array}$ & & 5000 & & Phytoextraction & 5.0 & Arshad et al., 2008 \\
\hline $\begin{array}{l}\text { Pelargonium } \\
\text { (Attar) }\end{array}$ & & 4000 & & Phytoextraction & 4.0 & Arshad et al., 2008 \\
\hline Viola principis & & 2350 & & Phytoextraction & 2.4 & Wan et al., 2016 \\
\hline $\begin{array}{l}\text { Euphorbia } \\
\text { cheiradenia }\end{array}$ & & 1138 & & Phytoextraction & 1.1 & $\begin{array}{l}\text { Chehregani and } \\
\text { Malayeri, } 2007\end{array}$ \\
\hline Pteris vittate & As & 23,700 & 1000 & Phytoextraction & 23.7 & Ma et al., 2001 \\
\hline Pteris vittate & & 13,800 & & Phytoextraction & 13.8 & Tu et al., 2002 \\
\hline Pteris vittata & & 8331 & & Phytoextraction & 8.3 & Kalve et al., 2011 \\
\hline Pteris vittata & & 6017 & & Phytoextraction & 6.0 & Han et al., 2016 \\
\hline Pteris vittata & & 4106 & & Phytoextraction & 4.1 & Wan et al., 2016 \\
\hline Pteris ryukyuensis & & 3647 & & Phytoextraction & 3.6 & Srivastava et al., 2006 \\
\hline Pteris quadriaurita & & 2900 & & Phytoextraction & 2.9 & Srivastava et al., 2006 \\
\hline $\begin{array}{l}\text { Corrigiola } \\
\text { telephiifolia }\end{array}$ & & 2110 & & $\begin{array}{l}\text { Microbial assisted } \\
\text { phytoextraction }\end{array}$ & 2.1 & $\begin{array}{l}\text { Garcia-Salgado et al., } \\
2012\end{array}$ \\
\hline Pteris biaurita & & 2000 & & Phytoextraction & 2.0 & Srivastava et al., 2006 \\
\hline Pteris cretica & & 1800 & & Phytoextraction & 1.8 & Srivastava et al., 2006 \\
\hline $\begin{array}{l}\text { Eleocharis } \\
\text { acicularis }\end{array}$ & & 1470 & & Phytoextraction & 1.5 & Sakakibara et al., 2011 \\
\hline Arabidopsis halleri & $\mathrm{Zn}$ & 32,000 & 10,000 & Phytoextraction & 3.2 & Zhao et al., 2000 \\
\hline Potentilla griffithii & & 11,400 & & Phytoextraction & 1.1 & Hu et al., 2009 \\
\hline $\begin{array}{l}\text { Eleocharis } \\
\text { acicularis }\end{array}$ & $\mathrm{Cu}$ & 20,200 & 1000 & Phytoextraction & 20.2 & Sakakibara et al., 2011 \\
\hline $\begin{array}{l}\text { Aeolanthus } \\
\text { biformifolius }\end{array}$ & & 13,700 & & Phytoextraction & 13.7 & Chaney et al., 2010 \\
\hline Pteris vittata & $\mathrm{Cr}$ & 20,675 & 1000 & Phytoextraction & 20.7 & Kalve et al., 2011 \\
\hline Prosopis laevigata & & 5461 & & Phytoextraction & 5.5 & $\begin{array}{l}\text { Buendía-González et al., } \\
2010\end{array}$ \\
\hline
\end{tabular}

$\mathrm{Co} \geq 0.1, \mathrm{Sb} \geq 0.1, \mathrm{Cu} \geq 0.1, \mathrm{Ni} \geq 0.1, \mathrm{Mn} \geq 1.0$ and $\mathrm{Zn} \geq 1.0$. Table 3 presents some hyperaccumulator plants which can accumulate high levels of these metal(loid)s (many fold higher than the minimum threshold level of hyperaccumulators).
Currently, $>450$ hyperaccumulating plant species of 45 families fulfilling the criteria of being hyperaccumulator are known which represents $<0.2 \%$ of all angiosperms, the majority of them being $\mathrm{Ni}$ hyperaccumulators (75\%) (Verbruggen et al., 2009). These plant 
families mainly included Brassicaceae, Asteraceae, Violaceae, Fabaceae, Caryophyllaceae, Euphorbiaceae, Lamiaceae, Flacourtaceae and Poaceae (Bhargava et al., 2012; Bolan et al., 2014). Among these hyperaccumulating plant species, there are about 20 As hyperaccumulators (fern species) (Niazi, 2011; Niazi et al., 2016b), 1 $\mathrm{Cd}$ hyperaccumulator, $14 \mathrm{~Pb}$ hyperaccumulator, 30 Co hyperaccumulators, $34 \mathrm{Cu}$ hyperaccumulators, $>320 \mathrm{Ni}$ hyperaccumulators, 30 Se hyperaccumulator, $11 \mathrm{Zn}$ hyperaccumulator, and $10 \mathrm{Mn}$ hyperaccumulator (Ghosh and Singh, 2005). Most of the hyperaccumulator plant species can hyperaccumulate and hypertolerate only one metal. However, some plant species are capable to accumulate and tolerate more than one metal at high levels. The best known multi-metal hyperaccumulator plant species is Thlaspi caerulescens (Ali et al., 2013), which can hyperaccumulate $\mathrm{Ni}, \mathrm{Cd}, \mathrm{Pb}$, and $\mathrm{Zn}$; Thlaspi ochroleucum and Thlaspi goesingense can hyperaccumulate $\mathrm{Zn}$ and $\mathrm{Ni}$; and Thlaspi rotundifolium can hyperaccumulate $\mathrm{Zn}, \mathrm{Ni}$ and $\mathrm{Pb}$ (Keller and Hammer, 2004; Vogel-Mikuš et al., 2006). Some other plants species belonging to the Brassicacea, such as Brassica juncea, Brassica napus, Leguminosae milkvetch, Astragalus racemosus and serpentine-endemic shrub Alyssum are also known to accumulate more than one metal(loid) at high concentrations (Kotrba et al., 2009). More recently Sedum alfredii (Crassulaceae) has gained increased attention, as multi-metal hyperaccumulator for $\mathrm{Zn}, \mathrm{Pb}$ and $\mathrm{Cd}$ with $\mathrm{Zn}$ level reaching $<2 \%$ of shoot weight (Xiong et al., 2011).

Phytoextraction allows soils clean-up over a large scale with an uneven pollution pattern. The advantages of phytoextraction compared to other classical remediation methods are (i) highly economical, (ii) less disruptive to the soil and environment, (iii) no need of disposal sites, (iv) high public acceptance, (v) no excavation or transport of contaminated media, and (vi) feasible for multi-metal contaminated sites (Sheoran et al., 2016; Mahar et al., 2016). The disadvantages of phytoextraction are as follow (i) depends on the growing conditions essential for plants and microorganisms, (ii) large-scale tasks need considerable experience and expertise to agricultural equipment, (iii) depends on plant tolerance to metal(loid)s, (vi) relatively long time period required to completely remediate the sites. The potential of hyperaccumulator plant species to uptake and accumulate heavy metal(loid)s is of great significance. However, in depth mechanisms/processes involved in metal accumulation are so far less studied, and the physiological roles are not fully developed. Recent development in physiological processes of hyperaccumulation revealed mechanisms involved in metal hyperaccumulation. The mechanisms of heavy metal(loid)s hyperaccumulation include biochemical and biophysical processes. Essential pre-requisites of successful phytoextraction include increased metal uptake and translocation to aerial parts, enhanced loading of metals into xylem, detoxification of metals within plant (Bhargava et al., 2012; Sheoran et al., 2016).

Physiological studies revealed that enhanced metal xylem loading and transfer to the aerial plant parts is mediated by carrier proteins (Ali et al., 2013; Shahid et al., 2016). Several studies have recently revealed that the transporters proteins like CDF (cation diffusion facilitator), ZIP [zinc-regulated transporter proteins (ZRTP), Iron-regulated transporter proteins (IRTP)], HMA (heavy metal(loid) ATPase) and Nramp (natural resistance and macrophage protein) are associated with the enhanced transfer of heavy metal(loid)s to aerial tissues in hyperaccumulator plant species (Ovečka and Takáč, 2014; Shahid et al., 2016). These carrier proteins are generally found in intracellular or plasma membranes. Several proteins of ATP family (AtATM3 or AtADPR12), ZIP family (TcZNT1, ZIP4, ZIP6, ZIP7, ZIP9, ZIP10 etc), Nramp family (NRAMP1, NRAMP3, NRAMP 5), DMT family (IRT1), and CDF transporters (MTP1, MTP8, MPT11 etc.) were identified in Anemone halleri and Thlaspi caerulescens as being involved in metal uptake, vacuolar sequestration, xylem loading and enhanced translocation of metals (Verbruggen et al., 2009). A role of human divalent metal transporter, DMT1 in the transport of $\mathrm{Pb}$ via a pH-dependent process has been also evidenced (Bressler et al., 2004). IRT1 has been shown to transport Cd and $\mathrm{Zn}$ in different hyperaccumulator plant species (Connolly et al., 2002). Similarly, overexpression of AtMT2b in tobacco resulted in increased As accumulation in shoot tissues (Grispen et al., 2009). AtHMA3 (At4g30120) (a member of the P-type ATPase superfamily), is reported to be involved in $\mathrm{Zn}$ loading into the xylem of Anemone halleri.

Heavy metal(loid)s are capable to induce a range of biochemical, morphological, physiological disorders (Shahid et al., 2015a). Heavy metal(loid)s induced generation of ROS is one of the earliest response of plants to metal toxicity (Pourrut et al., 2008; Shahid et al., 2012c). Overproduction of ROS inside plant cells can induce oxidation and alteration of cellular proteins, amino acids, membrane lipids and DNA (Shahid et al., 2011; Adrees et al., 2015). Hyperaccumulator plant species adopt diverse strategies to avoid cellular injury and maintain their growth in metal-contaminated soil. One of the tolerance mechanisms adopted by plants constitutes various antioxidants to combat increased production of ROS. These enzymes include such as catalase (CAT), ascorbate peroxidase (APX), superoxide dismutase (SOD), peroxidase (POD), and glutathione reductase (GR), as well as antioxidants such as proline, cysteine, ascorbic acid, glutathione (GSH) and non-protein thiol (Shahid et al., 2013b). Several previous physiological studies showed that these enzymes and proteins can transform ROS into less-toxic products, thus limiting tissue dysfunction and cell injury (Shahid et al., 2014f, 2014g; Adrees et al., 2015). Plant species differing in metal tolerance show varying behaviour of certain enzymes under metal stress. Shahid et al. (2014a) also observed activation of antioxidative enzymes, including APX, CAT, SOD and under Pb stress in Vicia faba. Zouari et al. (2016) reported a significant increase in enzymatic (SOD, APX, GR) activities in the date palm when exposed to $\mathrm{Cd}$.

Hypertolerance is considered the key aspect that makes hyperaccumulation possible. Vacuolar sequestration of heavy metal(loid)s is an important aspect in hyperaccumulator plant species towards metal homeostasis (Shahid et al., 2014a; Adrees et al., 2015). Hyperaccumulator plants are capable to sequester and/or bind metals to vacuole to prohibit their otherwise toxic effects. In plants, some natural chelates such as phytochelatins (PCs), GSH and metallothioneins (MTs) are characterised as the best metal-chelating ligands for sequestration of metal(loid)s to vacuoles, and are main part of the metal detoxification system in plants (Ali et al., 2013; Shahid et al., 2016; Adrees et al., 2015). Heavy metal(loid)s complexation with MTs, GSH and PCs is an effective way to neutralise the toxic effects of metals, most likely because the metal-PC complexes are transferred and sequestered in the cell vacuole (Yadav, 2010). Phytochelatins can form mercaptide bonds with various metals and play an important role in their detoxification in plants (Shukla et al., 2013). Generally, the formation of PC-metal complex takes place in cytosol, which is then sequestrated in the vacuole (Shahid et al., 2016; Török et al., 2015), thereby reducing the concentration of ROS in the cytosol. The induction of phytochelatin synthase (PCS) genes in plants has shown enhanced heavy metal(loid) stress tolerance by regulating PCs production (Eapen and D'Souza, 2005; Zhang et al., 2013). Synthesis of PC is catalyzed by the PCS. The expression of PCS genes in transgenic N. tabacum increases Cd uptake and tolerance (Wawrzyński et al., 2006). In contrast, transgenic Arabidopsis thaliana plants that lack PCS were hypersensitive to $\mathrm{Hg}$ and $\mathrm{Cd}$ (Memon and Schröder, 2009).

5.3.1.4. Phytoextraction by genetically modified plants. It is well known that several genes are involved in metal uptake, root-shoot translocation, and sequestration in vacuole. These genes can be transferred into candidate plants for improved phytoremediation traits using genetic engineering. Use of genetic engineering in plant sciences is also becoming very popular in modern era to introduce a desirable trait from one to other plant species (Eapen and D'Souza, 2005; Clark and Pazdernik, 2015). For phytoextraction, using this technique, plants can be engineered 
- to adjust their rhizosphere to increase mobility of target metal,

- to modify metal speciation within plant system for better root-toshoot translocation,

- to enhanced metal tolerance,

- to transfer metals into less toxic forms through binding with organic acids and thiol-rich chelators,

- to sequester heavy metal(loid)s in vacuoles.

The introduction of a gene in a specific species depends on the objective of mutation. For example, phytostabilization requires plant engineering resulting in enhanced metal uptake and improved ability to sequester them in roots with limited translocation to aerial parts. In case of phytoextraction where increased uptake with enhanced translocation to areal parts is required can be achieved by genetically introducing genes responsible of (1) increasing metal absorption in root cells; (2) reducing root metal sequestration; (3) enhancing metal xylem loading and transferring them to shoots for storage in epidermal and mesophyll cells. Several key steps have recently been identified at the molecular level indicating the possibility of engineering metal hyperaccumulation in plants. Multi-fold increase in absorption, xylem loading, translocation to aerial shoot along with enhanced tolerance have been reported in bioengineered plants as compared to wild types, for some metal pollutants e.g. As in Arabidopsis thaliana (Guo et al., 2012), Zn in Lactuca sativa and Brassica oleracea (BarramedaMedina et al., 2014), Pb in Nicotiana glauca (Gisbert et al., 2003) and Cd in N. tabacum (Khoudi et al., 2013).

According to Eapen and D'Souza (2005) and Marques et al. (2009), the possible areas of genetic manipulation are: phytochelatins (for enhanced tolerance and sequestration of metals in vacuoles), metallotioneins (for metal hypertolerance), phytosiderophores (for enhanced growth, e.g., nicotianamine aminotransferase), oxidative stress mechanisms (for enhanced heavy metal(loid)s tolerance such as glutathione-S-transferase and peroxidase), ferritin (for enhanced root-shoot metal transfer, example is iron-binding protein ferritin), metal transporters (to improve xylem loading and translocation such as $\mathrm{Zn}$ transporter-ZAT gene), metabolic pathways (for metal hypertolerance, e.g. ars $C$ and $\gamma$-ECS genes), and phytohormones synthesis (for enhanced growth and biomass production such as giberellin). The genetic engineering of $A$. thaliana by an iron uptake ZIP transporter gene IRT1 renders Fe deficiency in these plants. Similarly, the high expression of HMA4 in Anemone halleri, encoding a P1B-type ATPase, has been reported to enhance root-to-shoot transport of $\mathrm{Zn}$ and $\mathrm{Cd}$ (Wong and Cobbett, 2009). Ma et al. (2008) showed that Lsi2 mutation, gene responsible for arsenite loading into the xylem, caused almost $50 \%$ decrease in As accumulation in rice shoot

However, the most common strategy involves in genetic engineering is the induction of proteins responsible for metal detoxification (MTs, PC and GSH) for genetic manipulations (Eapen and D'Souza, 2005). The induction of genes like GSH1 and GSH2, PCS, glyoxalases (glyoxalaseI and II), ATP sulfurylase (APS), cystathionine synthase (CTS), GR and serine acetyltransferase (SAT) have shown enhanced heavy metal(loid) stress tolerance by regulating GSH and PCs production (Zhu et al., 2009; Zhang et al., 2013). Increased expression of PCS has been endeavored to enhance heavy metal(loid)s plant tolerance. For example, Hu et al. (2016) reported that overexpression of OsLEA4 in transgenic rice plants conferred enhanced tolerance to heavy metal(loid)s stress compared with the wild type rice plants. The induction of a modified bacterial GSH1 gene (S1ptTECS) in A. thaliana resulted in $\mathrm{Hg}$ tolerance. The expression of SAT, GSH1 and PCS genes in transgenic tobacco ( $N$. tabacum) have increased Cd uptake in roots (Wawrzyński et al., 2006). Similarly, in the cytosol or chloroplast of Populus canescens, the overexpression of a bacterial GSH1 gene caused increased GSH level and tolerance to heavy metal(loid)s stress (Bittsánszkya et al., 2005). The lack of response in heavy metal(loid)s accumulation and tolerance could be due to the fact that PC synthesis is also governed by GSH production. Guo et al. (2008) showed that the overexpressing GSH1 and AtPCS1 in Arabidopsis thaliana, which encode g-glutamylcysteine synthetase ( $\mathrm{g}$-ECS) enhanced As accumulation and tolerance. Kumar et al. (2013) reported that GSH gene encoding in the Arabidopsis caused significantly enhanced heavy metal(loid)s accumulation and tolerance than the wild-type. Similarly, GSH1 and GSH2 genes encoding respectively in Escherichia coli and Brassica juncea resulted in higher concentrations of PCs, $\gamma \mathrm{GSH}$, and total non-protein thiols in mutant plants (Zhu et al., 1999), which increased tolerance to $\mathrm{Cd}$. The increased tolerance and accumulation of $\mathrm{Cd}$ and $\mathrm{As}$ has been reported by simultaneous overexpression of AtPCS1 and GSH1 genes in mutant plants. Overexpression of PCS due to mutation may sometime causes hypersensitivity to heavy metal(loid)s in some plants. For example, overexpression of AtPCS1 in transgenic Arabidopsis caused 12-25 fold higher accumulation of AtPCS1 mRNA, and enhanced PCs production 1.3-2.1 fold compared to wild-type plants (Lee et al., 2003). Similarly, transgenic Brassica and Nicotiana plants with enhanced GSH and PC levels due to overexpression of cysteine synthase, or APS-adenosine triphosphate sulphurylase showed higher $\mathrm{Cd}$ accumulation and tolerance than the wild-type plants (Verkleij et al., 2009).

5.3.1.5. Chelate assisted phytoremediation. The process of phytoextraction is often more time consuming than other physiochemical technologies, and it is usually limited by the low metal availability, uptake and translocation and plant biomass (Bhargava et al., 2012; Sheoran et al., 2016). Despite high levels in soil, most of the heavy metal(loid)s are sparingly soluble and available in soil (Mahar et al., 2016). Heavy metal(loid)s immobilization and binding with different soil constituents can significantly limit the potential for soil phytoextraction. For $>10$ years, chelate-assisted remediation of metals from contaminated soils has gained significant consideration as an economical alternative to conventional soil remediation techniques. Potential chelating agents include elemental sulfur, ammonium fertilizers, low molecular weight organic acids (LMWOAs), EDDS, EDTA, nitrilo triacetic acid (NTA), hydroxyethylene diamine triacetic acid (HEDTA) and humic substances (Shahid et al., 2012d; Saifullah et al., 2015). These chelating agents enhance the phytoextraction of $\mathrm{Pb}, \mathrm{Cd}, \mathrm{Cu}, \mathrm{Zn}$ and $\mathrm{Ni}$ (Evangelou et al., 2007). For example, HEDTA increased Pb concentration in soil solution by 1000 times (Saifullah et al., 2009).

Application of chelates to soils modifies the main way of heavy metal(loid) uptake by the plants from the symplast to the apoplast. It is reported that chelating agent form metal-chelate complexes which are taken up by the plant, mainly through a passive apoplastic pathway (Zhao et al., 2010; Shahid et al., 2014c). Synthetic chelates are well known to assist the movement of metals towards plant root by releasing metals from soil solids to soil solution, thus enhancing metal phytoavailability. Owing to their neutral charge, metal-chelate complexes do not make bonding with negatively charged cell wall constituents such as polysaccharides or carboxyl groups of rhizoderm (Shahid et al., 2012a). Metal-chelate complexes are reported to be readily uptaken by majority of the plant species, especially, accumulator plant species (Blaylock et al., 1997; Saifullah et al., 2009). Several previous studies showed significant increase in plant accumulation of $\mathrm{Pb}, \mathrm{Cd}, \mathrm{Ni}, \mathrm{Cu}$, and $\mathrm{Zn}$ from contaminated soil in the presence of synthetic chelates (Usman and Mohamed, 2009). The effect of synthetic chelates on heavy metal(loid) uptake and accumulation depends on the type of metal and plant, and varies from no to $>200$-times higher accumulations (Saifullah et al., 2009; Shahid et al., 2012a).

Among the chelating agents, EDTA is considered the most effective and tested mobilizing amendment for the remediation of metals especially Pb (Shahid et al., 2014c). EDTA is known to enhance heavy metal(loid)s uptake from the soil to $>1 \%$ of shoot dry biomass (Shahid et al., 2014c). Several factors are involved in EDTA-assisted enhanced uptake of heavy metal(loid)s by plants which include (i) enhanced phytoavailable metal concentration in soil, (ii) increased movement of metal-EDTA complex towards plant root, (iii) destruction of 
physiological barriers in roots by EDTA, (iv) limited binding between metal-EDTA complex and the negatively charged cell walls, and (v) enhanced xylem loading and transfer of metal-EDTA complex towards aerial parts (Saifullah et al., 2009; Shahid et al., 2014e). Recently, Cay et al. (2016) reported EDTA enhanced Cd phytoextaction by four ornamental plant species such as Lonicera japonica, Althaea rosea, Dahlia hybrida and Salvia virgata growing in the natural vegetation of Black Sea RegionTurkey.

Despite the potential effectiveness of chelate-assisted phytoremediation, some concerns have been voiced regarding the use of chelating agents such as EDTA owing to low decomposition, possible contamination of the ground water, adverse effects on the soil microorganisms (Lestan et al., 2008; Cay et al., 2016). Owing to high persistence and related environmental issues associated with the use of EDTA, numerous other alternative chelating agents have been recommended by various authors. Of these, EDDS and NTA have been proposed as promising and environmental friendly mobilizing agents (Saifullah et al., 2015). Application of EDDS can reduce leaching of metals, but not fully prevented, compared to EDTA (Saifullah et al., 2015). For example, Marques et al. (2007) reported that the addition of EDTA or EDDS significantly increased water extractable $\mathrm{Zn}$ concentration up to 4.0- and 3.1fold, respectively. Furthermore, LMWOAs such as tartaric, acetic, malic, citric and oxalic acids can also be used for heavy metal(loid) phytoextration as an alternative to persistent synthetic chelates (Shahid et al., 2012a). LMWOAs, being natural root exudates, have very low persistence in soil which varies with the type of soil, root exudates and the microbial activity of rhizosphere (Abbas et al., 2015). LMWOAs are reported to enhance dissolution of heavy metal(loid)s in soil and uptake by high biomass accumulating plant species (Evangelou et al., 2007; Shahid et al., 2012a). Root exudates from Zea mays, Nicotiana rustica and N. tabacum increased extractable concentration of $\mathrm{Cu}, \mathrm{Cd}$ and $\mathrm{Mn}$ (Mench and Martin, 1991). Chelate-assisted phytoextraction of heavy metal(loid)s from soil has not gained considerable acceptance because of its high leaching risk, relatively low efficiency and high cost.

\subsubsection{Microbial assisted phytoremediation}

As mentioned earlier, phytoextraction is usually limited by the low metal availability, uptake and translocation and biomass. Like chelate-assisted phytoextraction, microbial-assisted phytoextraction of heavy metal(loid)s also represents a promising method for contaminated soil remediation (Rajkumar et al., 2012). Microbial remediation refers to using microorganisms to induce the absorption, precipitation, oxidation and reduction of heavy metal(loid)s in the soil. Soil microbial association helps plants to grow well even under metal stress conditions. It is well established that plant growth-promoting and heavy metal(loid)s-resistant soil microorganisms can protect plants from the noxious effects of heavy metal(loid)s, or even increase metal uptake by hyperaccumulator plants (Weyens et al., 2009a, 2009b). Microorganisms-assisted remediation of heavy metal(loid)s can be via several mechanisms such as biosorption, intracellular accumulation, enzyme-catalyzed transformation, bioleaching and biomineralization, redox reactions (Lloyd, 2002). Metal-resistant rhizobacteria are capable to stimulate growth and metal accumulation by plants through the production of various substances i.e., monocyclopropane-1-carboxylate (ACC) deaminase and siderophores, indole acetic acid (IAA) (Rajkumar et al., 2012). Moreover, metal-resistant rhizobacteria enhance metal tolerance of host plants by inducing thiol compounds (Courbot et al., 2004), superoxide dismutase (Vallino et al., 2009) or metallothionein (Ramesh et al., 2009). Inoculation of Burkholderia sp. (Z-90) enhanced heavy metal(loid)s removal efficiency in soil by $31 \%$ for $\mathrm{Pb}$, $32 \%$ for As, $44 \%$ for $\mathrm{Zn}, 37 \%$ for Cd, $52 \%$ for $\mathrm{Mn}$ and $24 \%$ for $\mathrm{Cu}$ (Yang et al., 2016). Ma et al. (2015) reported that Sedum plumbizincicola significantly enhanced Cd uptake (43\%), whereas Bacillus sp. (E1S2) enhanced the $\mathrm{Zn}$ accumulation (18\%) in Sedum plumbizincicola. Moreover, microbial association causes several other beneficial effects on plant growth such as stomatal regulation, osmotic adjustment, and enhanced uptake of minerals (Compant et al., 2005).

Soil bacteria can enhance metal mobility and bioavailability in soil via several ways, such as lowering soil $\mathrm{pH}$, producing plant growth promoting and metal-chelating compounds such as siderophores, organic acids, biosurfactants and by altering soil redox conditions (Ahemad, 2014; Ullah et al., 2015). Bacteria such as Bacillus mucilaginosus (Ksolubilizer), Bacillus megaterium (P-solubilizer) and Azotobacter chroococcum ( $\mathrm{N}$-fixer bacteria) can lower soil $\mathrm{pH}$ value, possibly by secreting LMWOAs, thereby increasing the bioavailability of $\mathrm{Zn}, \mathrm{Pb}$ and Cd (Chen et al., 2005). However, the effect of soil microorganisms on metal solubility and uptake by plants is not always similar (Ma et al., 2015). Soil microorganisms may increase or decrease metal uptake by plants (Ahemad, 2014; Ma et al., 2015). Indeed, certain microbial processes can increase metal solubility and bioaccumulation, whereas other processes may cause metal immobilization, thus decreasing their phytouptake (Gadd, 2010). Saravanan et al. (2007) reported increased solubilization of $\mathrm{Zn}$ compounds by microorganisms by producing 5-ketogluconic acid. Braud et al. (2009) showed 113\% enhanced exchangeable $\mathrm{Pb}$ fraction in soil with Pseudomonas aeruginosa and Pseudomonas fluorescens. Abou-Shanab et al. (2006) reported Microbacterium arabinogalactanolyticum assisted 15-folds increase of extractable Ni concentration in the soil. Paxillus involutus enhanced the concentrations of extractable $\mathrm{Zn}, \mathrm{Cd}, \mathrm{Pb}$ and $\mathrm{Cu}$ respectively by $1.33,1.22,1.33$ and 1.11 times compared to non-bioaugmented soil (Baum et al., 2006). Sheng et al. (2008) observed that Pb accumulation increased by $131 \%$ with $P$. fluorescens and $80 \%$ with Microbacterium sp. in the shoots of B. napus. Xiong et al. (2008) observed significant increase in the uptake of $\mathrm{Zn}, \mathrm{Cd}$, and $\mathrm{Pb}$ by Sedum alfredii by rhizosphere microorganisms.

\section{Comparison of remediation techniques for their applicability and selection}

There exist several important factors which can affect the selection and applicability of available soil clean-up technologies. These factors include: (i) cost involved, (ii) time required, (iii) effectiveness under high metal(loid)s contamination, (iv) general acceptance and commercial availability, (v) long-term effectiveness, and (vi) applicability to multi-metal contaminated sites (Table 4).

\subsection{Economic considerations of remediation techniques}

Management of soil pollution is a major economic challenge worldwide. In addition to societal and environmental acceptability aspects, cost involved is the key factor determining the success and practical application of remediation technology in the field conditions. Studies regarding economic aspect of soil remediation with heavy metal(loid)s are scarce. Generally, various factors contribute to the cost involved for remediation of polluted site including those related to contaminated site (such as type and depth of soil, depth of groundwater, possible migration pathways and purpose of remediation), the heavy metal(loid)s (such as type of metal, and concentration of metal in soil) and the remediation technology (various technologies have different requirements and cost of action).

Physical remediation methods generally require large amount of manpower and material resources. Excavation is generally the most expensive remediation approach when large amount of soil has to be removed or disposed. Chemical remediation (immobilization and soil washing) is a cost-effective technique compared to physical remediation methods. The amount of chemicals required in heavy metal(loid) immobilization or soil washing is generally not very high due to comparatively low applied doses of chemical extractants or immobilizing agents such as EDTA. However, the cost of chemical remediation of 
Table 4

Comparison of different soil clean-up methods.

\begin{tabular}{|c|c|c|c|c|c|c|c|}
\hline Techniques & Process involved & Advantages & Limitations & Applicability & Acceptance & $\begin{array}{l}\text { Multi-metal } \\
\text { sites }\end{array}$ & Time required \\
\hline \multicolumn{8}{|l|}{ Physical remediation } \\
\hline Soil replacement & $\begin{array}{l}\text { Excavating contaminated soil } \\
\text { and replacing by } \\
\text { non-contaminated soil }\end{array}$ & $\begin{array}{l}\text { Can effectively } \\
\text { isolate HM from } \\
\text { contaminated site. } \\
\text { Effective for highly } \\
\text { contaminated soils. }\end{array}$ & $\begin{array}{l}\text { Large in working volume, } \\
\text { costly, production of dangerous } \\
\text { waste and negative effect on } \\
\text { soil }\end{array}$ & $\begin{array}{l}\text { Small scale } \\
\text { but long term }\end{array}$ & $\begin{array}{l}\text { Very low: } \\
\text { limited to } \\
\text { highly } \\
\text { contaminated } \\
\text { soils }\end{array}$ & Effective & $\begin{array}{l}\text { Comparatively } \\
\text { very less }\end{array}$ \\
\hline Soil isolation & $\begin{array}{l}\text { Isolating the contaminated } \\
\text { soil from the uncontaminated } \\
\text { soil using subsurface barriers }\end{array}$ & $\begin{array}{l}\text { Prevent off-site } \\
\text { transport of heavy } \\
\text { metals, Effective } \\
\text { for highly } \\
\text { contaminated soils. }\end{array}$ & $\begin{array}{l}\text { Costly, soil clean up still needs } \\
\text { further engineering measures, } \\
\text { effectiveness varies with the } \\
\text { typeof subsurface barrier }\end{array}$ & $\begin{array}{l}\text { Small scale, } \\
\text { and short to } \\
\text { long term }\end{array}$ & $\begin{array}{l}\text { Very low: } \\
\text { limited to } \\
\text { highly } \\
\text { contaminated } \\
\text { soils }\end{array}$ & Effective & $\begin{array}{l}\text { Comparatively } \\
\text { very less }\end{array}$ \\
\hline Vitrification & $\begin{array}{l}\text { Reduction in metal } \\
\text { bioavailability by forming } \\
\text { vitreous material using } \\
\text { high-temperature }\end{array}$ & $\begin{array}{l}\text { Easy application, } \\
\text { applicable to } \\
\text { variety of } \\
\text { contaminants }\end{array}$ & $\begin{array}{l}\text { High cost due to energy } \\
\text { requirement }\end{array}$ & $\begin{array}{l}\text { Small scale } \\
\text { but long term }\end{array}$ & Very low & Effective & $\begin{array}{l}\text { Comparatively } \\
\text { very less }\end{array}$ \\
\hline $\begin{array}{l}\text { Electrokinetic } \\
\text { remediation }\end{array}$ & $\begin{array}{l}\text { Removal of HM from soil via } \\
\text { electrophoresis, or } \\
\text { electro-migration by } \\
\text { applying DC-voltage }\end{array}$ & $\begin{array}{l}\text { Easy application, } \\
\text { economically } \\
\text { effective, do not } \\
\text { destroy the nature } \\
\text { of soil }\end{array}$ & $\begin{array}{l}\text { Requires soil with low } \\
\text { permeability, pH needs to be } \\
\text { controlled }\end{array}$ & $\begin{array}{l}\text { Small scale } \\
\text { but long term }\end{array}$ & Very low & Effective & $\begin{array}{l}\text { Comparatively } \\
\text { very less }\end{array}$ \\
\hline \multicolumn{8}{|l|}{ Chemical remediation } \\
\hline Immobilization & $\begin{array}{l}\text { Reduction in metal mobility } \\
\text { and bioavailability by } \\
\text { applying immobilizing } \\
\text { amendment, and forming } \\
\text { stable and immobile } \\
\text { complexes via adsorption }\end{array}$ & $\begin{array}{l}\text { Fast and easy } \\
\text { applicability, } \\
\text { relatively low } \\
\text { costs, covers a } \\
\text { broad spectrum of } \\
\text { inorganic } \\
\text { pollutants }\end{array}$ & $\begin{array}{l}\text { Temporary solution and } \\
\text { permanent monitoring is } \\
\text { necessary }\end{array}$ & $\begin{array}{l}\text { Small to } \\
\text { medium scale } \\
\text { and } \\
\text { short-term }\end{array}$ & $\begin{array}{l}\text { High public } \\
\text { acceptability }\end{array}$ & $\begin{array}{l}\text { Can be effective. } \\
\text { Depends on the } \\
\text { type of soil, } \\
\text { metal and } \\
\text { immobilizing } \\
\text { amendment }\end{array}$ & Less to medium \\
\hline Soil washing & $\begin{array}{l}\text { Removal of heavy metals } \\
\text { from soil by extractants } \\
\text { (organic or inorganic) and } \\
\text { forming stable and mobile } \\
\text { complexes }\end{array}$ & $\begin{array}{l}\text { Cost-effective, } \\
\text { completely } \\
\text { removes metals, } \\
\text { meets specific } \\
\text { criteria and } \\
\text { reduces long-term } \\
\text { liability }\end{array}$ & $\begin{array}{l}\text { Washing extractants may cause } \\
\text { environmental issue, } \\
\text { effectiveness varies with soil, } \\
\text { metal and extractant type }\end{array}$ & $\begin{array}{l}\text { Small scale } \\
\text { but can be } \\
\text { long term }\end{array}$ & $\begin{array}{l}\text { Medium to } \\
\text { high public } \\
\text { acceptability }\end{array}$ & $\begin{array}{l}\text { Can be effective. } \\
\text { Depends on the } \\
\text { type of soil, } \\
\text { metals and } \\
\text { mobilizing } \\
\text { amendment }\end{array}$ & Less to medium \\
\hline \multicolumn{8}{|c|}{ Biological remediation } \\
\hline Phytovolatilization & $\begin{array}{l}\text { Heavy metal uptake by plants } \\
\text { from soil and release in } \\
\text { vapour form to atmosphere }\end{array}$ & $\begin{array}{l}\text { Economical and } \\
\text { less disruptive }\end{array}$ & $\begin{array}{l}\text { Restricted to volatiable metals, } \\
\text { may cause other environmental } \\
\text { issues, no control after metal } \\
\text { release to atmosphere }\end{array}$ & $\begin{array}{l}\text { Small to } \\
\text { medium scale } \\
\text { and } \\
\text { long-term }\end{array}$ & $\begin{array}{l}\text { Low-medium } \\
\text { public } \\
\text { acceptability }\end{array}$ & No & Very high \\
\hline Phytostabilization & $\begin{array}{l}\text { Use of plants to decrease } \\
\text { metal bioavailability and } \\
\text { mobility in soils via } \\
\text { sequestration in plant roots }\end{array}$ & $\begin{array}{l}\text { Economical, less } \\
\text { disruptive }\end{array}$ & $\begin{array}{l}\text { Temporary solution, } \\
\text { effectiveness varies with soil, } \\
\text { plant and metal type }\end{array}$ & $\begin{array}{l}\text { Small to } \\
\text { medium scale } \\
\text { and } \\
\text { short-term }\end{array}$ & $\begin{array}{l}\text { Medium } \\
\text { public } \\
\text { acceptability }\end{array}$ & Very low & Very high \\
\hline Phytoextraction & $\begin{array}{l}\text { Use of hyperaccumulator } \\
\text { plants to uptake, translocate, } \\
\text { and concentrate heavy } \\
\text { metals from soil to the } \\
\text { aboveground harvestable } \\
\text { plant parts }\end{array}$ & $\begin{array}{l}\text { Highly economical, } \\
\text { ecofriendly, less } \\
\text { disruptive }\end{array}$ & $\begin{array}{l}\text { Effectiveness depends on } \\
\text { growing conditions, tolerance } \\
\text { of the plant, bioavailability of } \\
\text { metals in soil. Metal } \\
\text { accumulator plants are } \\
\text { generally very less in number }\end{array}$ & $\begin{array}{l}\text { Large-scale } \\
\text { and } \\
\text { long-term }\end{array}$ & $\begin{array}{l}\text { Highest } \\
\text { public } \\
\text { acceptability }\end{array}$ & $\begin{array}{l}\text { Generally very } \\
\text { low except for } \\
\text { some plants }\end{array}$ & Very high \\
\hline $\begin{array}{l}\text { Chelate assisted } \\
\text { phytoextraction }\end{array}$ & $\begin{array}{l}\text { Use of organic and inorganic } \\
\text { ligands to enhance } \\
\text { phytoextraction capacity of } \\
\text { plants }\end{array}$ & $\begin{array}{l}\text { Low time of } \\
\text { remediation, } \\
\text { enhance metal } \\
\text { uptake and } \\
\text { translocation }\end{array}$ & $\begin{array}{l}\text { Costly, can be disruptive, } \\
\text { effective for low-moderately } \\
\text { contaminated soils, } \\
\text { groundwater contamination } \\
\text { risk }\end{array}$ & $\begin{array}{l}\text { Small to } \\
\text { medium scale } \\
\text { and } \\
\text { long-term, } \\
\text { low to } \\
\text { moderate } \\
\text { levels of } \\
\text { metal }\end{array}$ & $\begin{array}{l}\text { Very high } \\
\text { public } \\
\text { acceptability }\end{array}$ & $\begin{array}{l}\text { Generally very } \\
\text { low but more } \\
\text { effective than } \\
\text { phytoextraction } \\
\text { alone }\end{array}$ & $\begin{array}{l}\text { Very high but } \\
\text { less than } \\
\text { phytoextraction } \\
\text { alone }\end{array}$ \\
\hline $\begin{array}{r}\text { Microbial assisted } \\
\text { phytoextraction }\end{array}$ & $\begin{array}{l}\text { Use of microorganisms to } \\
\text { enhance phytoextraction } \\
\text { capacity of plants }\end{array}$ & $\begin{array}{l}\text { Economical, low } \\
\text { time of } \\
\text { remediation, } \\
\text { enhance plant } \\
\text { growth and metal } \\
\text { uptake and } \\
\text { translocation }\end{array}$ & $\begin{array}{l}\text { Depends on microorganism, } \\
\text { soil, plant and metal type }\end{array}$ & $\begin{array}{l}\text { Large-scale } \\
\text { and } \\
\text { long-term }\end{array}$ & $\begin{array}{l}\text { Very high } \\
\text { public } \\
\text { acceptability }\end{array}$ & $\begin{array}{l}\text { Generally very } \\
\text { low but more } \\
\text { effective than } \\
\text { phytoextraction }\end{array}$ & $\begin{array}{l}\text { Very high but } \\
\text { less than } \\
\text { phytoextraction } \\
\text { alone }\end{array}$ \\
\hline
\end{tabular}

soil varies with the type of metal and soil as well as that of chemical extractants or immobilizing agents. For example, soil washing is easy for $\mathrm{Cd}$ than $\mathrm{Pb}$ due to immobile nature and high affinity of $\mathrm{Pb}$ for soil constituents. Similarly, soil washing requires more chemicals for clayey soil than sandy soils due to strong binding of metals in clayey soils. In case of extractants or immobilizing agents, applied levels/concentrations of synthetic chelates such as EDTA are 10-50 times higher than natural ligands LMWOAs or humic substances (Shahid et al., 2012a). 
Bioremediation is relatively economical compared to physical and chemical remediation techniques. All the types of bioremediation generally harnesses natural processes and treat the metal contaminated sites in place without any excavation or physical removal, thereby reducing the cost of site clean-up. Besides, in some cases bioremediation can remove or contain heavy metal(loid)s without any human involvement and this natural attenuation results in considerable cost savings. For example, since phytoremediation can operate with minimal maintenance after its establishment in the field, therefore phytoremediation costs almost ten-fold less than engineering-based methods (Marques et al., 2009). Likewise, post-clean-up cost is very low for bioremediation methods because these methods causes minimum site disturbance compared with conventional physical clean-up methods.

Blaylock et al. (1997) estimated cost for remediating one acre of $\mathrm{Pb}$ contaminated soil. They reported that the cost of phytoremediation ( $€ 140-230$ ) is $50-65 \%$ less compared to conventional treatments such as excavation and landfill (€460). According to the US EPA (2004), phytoremediation costs about US $\$ 25$-US $\$ 100$ per ton of soil as compared to vitrification 300-500 US\$/ton and flushing 75-210 US\$/ton. Schnoor (1997) compared the cost of different remediation techniques for heavy metal(loid) contaminated sites, and reported phytoremediation to be the most cost effective (US\$10-35) than in situ bioremediation (US\$50-150), stabilization/solidification (US\$240-340), soil venting (US\$20-220), solvent extraction (US\$360440 ), soil washing (US\$80-200) and incineration (US\$200-1500). Cunningham and Ow (1996) showed that the estimated 30-years cost for cleaning-up 12-acre of $\mathrm{Pb}$ contaminated soil was $€ 185,000$ for phytoextraction, $€ 555,000$ for soil capping, $€ 5,833,000$ for soil washing and $€ 11,100,000$ for excavating and disposal. Salt et al. (1995) reported that to remediate one acre of sandy loam soil upto a depth of $50 \mathrm{~cm}$, phytoextraction costs ( $€ 55,000$ to $€ 92,500)$ almost $4-7$ times than soil excavation (€370,000).

Phytoextration of heavy metal(loid) contaminated soil in combination with the use of chelating agents can further reduce the cost of phytoremediation by enhancing heavy metal(loid) plant uptake and translocation upto 200-fold. Chaney et al. (2002) reported that phytoextration of $\mathrm{Pb}$ contaminated soil using EDTA (10 mmol EDTA kg ${ }^{-1}$ ) would cost approximately US $\$ 30000 \mathrm{ha}^{-1}$ to attain $\mathrm{Pb}$ level of $10 \mathrm{~g} \mathrm{~kg}^{-1}$ dry weight. EDTA reduces the cost of remediation because field scale application of EDTA is not very high (2.5 to $10 \mathrm{mM}$ ) (Shahid et al., 2012b). Moreover, other costs of heavy metal(loid) remediation such as designing, maintenance, installation and operation remain same as for phytoextraction without EDTA application. The extent to which cheating agents reduces the cost of phytoremediation varies with soil, metal and plant type (Shahid et al., 2014c). This is because effect of different chelating agents on heavy metal(loid) mobility, bioavailability, uptake and translocation varies with soil, metal and plant type. Application of chelating agents can also minimize the time required for remediation and thereby reduces the cost of remediation. Similar to chelate-assisted, microbial-assisted phytoextraction or use of genetically engineered plants can further reduce cost of remediation by enhancing metal accumulation and decreasing remediation time. Moreover, operational costs remain the same as for phytoextraction alone.

\subsection{Time required for different remediation techniques}

Physical remediation methods require minimum time among different remediation technologies available. Indeed, physical remediation involves either replacement or removal of soil or installation of barriers. Therefore, physical remediation methods are considered most effective with respect to the time required for complete remediation of polluted sites. Chemical remediation techniques are also fast but their effectiveness varies with metal, soil and chemical type. Certain chemicals can immobilize or washout great quantities of metals compared to others but the effect is greatly dependent on soil conditions especially soil $\mathrm{pH}$.
In case of phytoremediation, major limitation for cleanup of heavymetal-polluted soils is the long time period required to completely remediate the sites (Bhargava et al., 2012). Several factors influence the time required for complete or targeted remediation of a contaminated sites. These factors include metal levels found in the contaminated soil, heavy metal(loid) mobility in soil, translocation to aerial parts, target metal final concentrations, plant biomass and rates of plant growth (Shahid et al., 2012a). Time required for complete remediation of contaminated sites may also vary with the type of soil, plant and metal as well as the soil depth of remediation required (Arshad et al., 2008; Rajkumar et al., 2012). Despite high levels in soil, most of the heavy metal(loid)s are only low-soluble and phytoavailable (Rascio and Navari-Izzo, 2011). Moreover, majority of the hyperaccumulators are slow growing with low plant biomass and therefore require long time period to completely remediate the soil. Similarly, the objective of remediation also affects the time required for remediation due to variation in geochemical background values of heavy metal(loid)s fixed by regulations of a country.

Chelates- and microbial-assisted as well as use of transgenic plant species can greatly reduce the time required for complete remediation of contaminated site. For example, several studies showed that application of EDTA can enhance bioaccumulation index of metal(loid)s in plants by a factor of 200 times. Nevertheless, it is not true for all the metals and plants or under all plants growth conditions. Shahid et al. (2012b) modelled the phytoremediation efficiency of pelargonium cultivated on a multi-metal contaminated site $(\mathrm{Pb}, \mathrm{As}, \mathrm{Cd}, \mathrm{Zn}$ and $\mathrm{Cu}$ levels in the bulk soil were $39,250,1060,706,3995$ and $2085 \mathrm{mg} \mathrm{kg}^{-1}$ DW respectively). They showed that complete remediation of this site may take $>35$ years at an annual removal of $2.7 \%$ by pelargonium. They estimated that EDTA can further minimize this time to 7 years, if the metal(loid) accumulation by pelargonium is enhanced by a factor of 5 -times. Nevertheless, the decrease in time required for complete clean-up of heavy metal(loid) contaminated soil might be affected by the potential toxicity of EDTA and/or metal-EDTA complexes to plants and microorganisms, thereby decreasing plant biomass and, consequently, reduced metal(loid)s bioaccumulation. It means, assisted phytoextration needs proper management.

\subsection{Applicability of different remediation techniques to high metal and multi-metal contamination}

During physical remediation methods, the entire contaminated soil is either replaced or isolated, therefore this method can be applied to soils polluted with more than one heavy metal(loid)s at high level. Application of physical remediation is considered to be most effective for highly contaminated sites containing different kinds of pollutants. In case of chemical remediation methods (immobilization and washing), effectiveness to clean-up soils containing high levels of more than one heavy metal(loid)s depends on the types of metals, soils and chemical extractants. Some extractants such as EDTA has high affinity for several metals under wide range of soil conditions. Therefore, soil washing using EDTA can be effective for high metal and multi-metal contaminated sites. On the other hand, efficiency of certain chemical extractants such as LMWOAs varies greatly with soil conditions (especially with soil $\mathrm{pH}$ ) and metal type. Therefore these extractants cannot be applied to high metal and multi-metal contaminated sites. Similarly, heavy metal(loid) immobilization using chemical reagent may not be feasible for multi-metal contaminated sites as there are very rare reagents having immobilization capacity for all kinds of metals.

Bioremediation can be applied to multi-metal contaminated soils because some hyperaccumulators can grow and accumulate high levels of various metals. However, majority of the hyperaccumulator plants generally uptake only a specific metal, and are not appropriate to be applied in the field under multi-metal contaminated soil conditions. Bioremediation is generally restricted to low or moderately contaminated sites because majority of the plants and microorganisms cannot survive 
under severe heavy metal(loid) levels in soil. Phytoextraction is effective only for soils containing easily available heavy metal(loid)s. Some heavy metal(loid)s, such as $\mathrm{Cr}$ and $\mathrm{Pb}$ are highly immobile in soils, and their phytoextraction is often limited. The efficiency of phytoextraction is also limited by the depth accessible for plant root growth (generally $30-90 \mathrm{~cm}$ ). However, the application of chelating agents may enhance the ability of phytoextration to remediate multi-metal contaminated sites due to increased heavy metal(loid) bioavailability is soil, and accumulation as well as translocation inside plants.

\subsection{Long-term effectiveness of different remediation techniques}

Physical remediation methods (soil replacement and electrokinetic remediation) can completely remove heavy metal(loid)s from contaminated soil. Therefore, there is very little long-term liability using these physical remediation methods. These methods can be highly effective in term of long-term effectiveness due to complete removal of heavy metal(loid)s. However, soil isolation, subsurface barriers and vitrification do not have long-term effectiveness, because under these remediation techniques, the contaminants are still in the site and need continuous maintenance/conservation. Chemical remediation methods (immobilization and washing) are not highly effective for long period of times owing to different limitations associated with these methods. For example, heavy metal(loid) immobilization is only a short-term solution because the metals are still retained in the soil. The immobilized heavy metal(loid)s may become active (mobile) when soil physicochemical properties change, therefore, these remediation techniques require permanent monitoring. Chemical remediation has high invasivity to the environment and danger of the release of additional contaminants to the environment.

Phytoextraction has long-term effectiveness because the contaminants are removed from the site and there is no need of disposal sites. All the types of bioremediation generally harnesses natural processes and treat the metal contaminated sites in place without any excavation or physical removal. However, storage, treatment and placement of contaminated plant biomass may affect long-term effectiveness of phytoremediation. One of the most safe and economical approaches of utilizing the contaminated plant biomass is its use as a source of energy. Combustion and gasification are important approaches used for producing electric and thermal energies from contaminated plant biomass. Another operational method is thermochemical processing of contaminated plant biomass on pyrolysis. Similarly, ashing of plant biomass can produce bio-ores especially after the phytomining of precious metals.

Phytostabilization of metals does not reduce the concentration of the contaminants but the contaminants are left in place. Therefore, the site requires regular monitoring to ensure that the optimal stabilizing conditions are sustained. The conversion of heavy metal(loid)s to volatile form and subsequent release into the atmosphere by plants during phytovolatilization is restricted by the fact that the process does not fix the contaminant completely; only transfers pollutants from soil to atmosphere from where it can be redeposited.

Similarly, chelate-assisted remediation of heavy metal(loid)s can also cause off-site movement of heavy metal(loid)s (Shahid et al. 2014c). During EDTA-assisted solubilization of heavy metal(loid), plants can absorb only a limited fraction of mobilized metal and the remaining amount of heavy metal(loid)s are generally leached down (Saifullah et al., 2015). Therefore, it is highly necessary that application of chelating agents is limited to their lowest level for ecological and economic benefits. The key necessities under chelate-assisted remediation are optimal methods and applied levels as well as rapid degradation following their application. Presence of EDTA in soil can negatively affect soil enzymatic and microbial activities as well as soil fungi, and plants. EDTA is also reported to deteriorate the chemical properties and physical structure of soils. Some authors reported that split application of EDTA or in combination with other easily degradable organic ligands like NTA or EDDS can decrease metal leaching (Saifullah et al., 2009). Moreover, use of easily degradable organic ligands like NTA or EDDS can be better option for the remediation of metal polluted soil (Saifullah et al., 2015). Therefore, due to low degradability and long persistence in environment, chelate-assisted remediation does not have long-term effectiveness.

\subsection{General acceptance/application of different remediation techniques}

The application and acceptance of different remediation methods depends on various factors such as area of contamination, type and amount of contaminant, purpose of contamination etc. Physical remediation methods are generally applicable to small-scales contaminated sites such as residential areas or small sites near a factory etc. These methods also have high application to multi-metal contaminated sites. Physical remediation methods are generally not applicable to agricultural areas owing to their destructive nature and lose of soil fertility. On the other hands, chemical and bioremediation methods can be applied to large areas (especially bioremediation) such as agricultural fields owing to their non-destructive nature. Moreover, bioremediation requires the same agronomic practices and is easy to apply to agricultural areas.

\section{Future development for clean-up of heavy metal(loid)s polluted sites}

Financial and technical implications and complexities have made soil clean-up a challenging task. Compared to physico-chemical methods, bioremediation of heavy metal(loid)s contaminated soils shows great advantage with respect to environmental safety, fieldscale application, public acceptability and cost involved. Although, field-scale application of bioremediation faces several practical and technical limitations, but following proper management and advancement in this field, these limitations can be minimized. This is because studies regarding bioremediation of heavy metal(loid)s contaminated soils field are increasing and its mechanism is clear.

The first way to use bioremediation is developing more systematic use on low-contaminated industrial or urban sites to reduce soil metal content and promote fertility. A second way is the use of bioremediation on the low-contaminated sites once the highly-contaminated soils have been excavated. The third approach can be the use of transgenic technology to improve bioremediation efficiency and effectiveness as well as field-scale application. Through the introduction of foreign resistant genes, the possibility to create an ideal plant species for clean-up of heavy metal(loid)s contaminated soil is feasible. Several researchers have proposed that establishing ideal crop hyperaccumulator in the future can be an ideal choice due to its feasibility and applicability in the field of which current emphasis is scarce. By mean of genetic engineering, ability of a plant to accumulate, translocate and detoxify heavy metal(loid)s can be significantly enhanced. An ideal transgenic plant species for phytoremediation must has ability to produce high biomass, appropriately competitive in harsh climatic conditions, good phytoremediation capacity, has a widespread and branched root system, capable to mobilize, absorb, transfer and sequester metals preferably in the aboveground parts, easy to harvest, and is suitable for genetic transformation. However, no plant is known to date that meets all these criteria. Establishing an ideal plant species for hyperaccumulation and hypertolerance is not possible until the availability of complete hyperaccumulator genome sequences. Our understanding of hyperaccumulator genome sequences and evolution could be greatly improved by merging ecological and molecular genomics. One of the important research avenues is the pursuit for signatures of latest adaptive evolutions across candidate genes for metal hypertolerance or hyperaccumulation. Using genetic engineering, several heavy metal(loid)s resistant genes responsible for enhanced expression of specific protein have been introduced successfully into plant cells. Due to over 
expression of specific protein and natural chelators (MTs, PCs and organic acid) in transgenic plants, their ability of heavy metal(loid)s accumulation, translocation in xylem and tolerance is improved. The different processes/mechanisms introduced in plants via transgenic technology includes excretion of certain transporter proteins, binding and transportation of specific metal ions and volatilization of heavy metal(loid)s by encoding special oxidoreductase such as MerA and MerB.

In addition to the use of transgenic plants, plant-microbes associations, in many cases, are highly efficient in absorbing, accumulating, translocation and tolerating heavy metal(loid)s because of their capacity to produce various substances (IAA, ACC etc.). Therefore, finding and establishing an appropriate kind of symbiotic bacteria using genetic engineering can be highly effective in bioremediation. Another major advantage of microbial association can be the production of some necessary nutrients and even plant growth hormones by microorganisms. Moreover, despite environmental concerns associated with chelateassisted bioremediation, several studies reported/suggested techniques to overcome environmental concerns of synthetic chelates such as split application, combined application, application at proper stage of plant growth, sub-irrigation drainage systems and application to loamy soil. These management practices of using chelate-assisted remediation can be jointly applied with transgenic plants and smicrobes assisted heavy metal(loid)s remediation. Besides, the role of agronomic practices/strategies needs to be explored for increasing the biomass and thus phytoextraction potential of natural hyperaccumulators. Similarly, there is also need to pursuit the role of plant growth regulators (indolebutyric acid, cytokinins, gibberellic acid, naphthylacetic acid and indole-3-acetic acid) to increase the biomass potential of hyperaccumulating plants. Therefore, establishing an optimum soil + plant + microbes combination using transgenic technology can be a promising way in the future development. However, for judicial and environmentally safe application of optimum plant + soil + microbes combination, a full understanding of important processes and factors related to metal and chelate type, soil physicochemical properties, and plant and microbe species and association is necessary.

\section{Conclusions and perspectives}

Soil contamination by heavy metal(loid)s is a worldwide problem, therefore effective remediation approaches are necessary. A number of remediation techniques are used for effective remediation of contaminated sites. In this review we compared the effectiveness of different remediation techniques generally used to clean-up contaminated soils. Technical and financial implications have made soil remediation a complex and difficult task. Most traditional soil remediation techniques do not offer acceptable solutions for the cleanup of heavy metal(loid)s polluted sites. Physical remediation methods can completely remove heavy metal(loid)s from contaminated soil but are destructive in nature and highly costly. These methods can only be applied to small area of soils. Chemical remediation methods are fast, simple, easy to apply, high public acceptability and relatively economical. However, these remediation methods are not eco-friendly because they have limitations of releasing additional contaminants to the environment. Phytoextraction is safe, least destructive, eco-friendly and cost-efficient remediation technique which allows soils clean-up over a large scale. However, still fundamental and field-scale research is needed in this field. Effectiveness of phytoremediation depends on the growing conditions, plant tolerance to metal and solubility of metals in soil. The process of phytoextraction is often more time consuming and is effective for low-to-moderate levels of heavy metal(loid)s.

Phytoremediation can be used effectively in combination with several other traditional remediation techniques; chelate assisted, microbial assisted and transgenic plants. Chelate-induced remediation of heavy metal(loid)s by high biomass species is the most efficient technique due to enhanced metal solubilization, uptake and translocation. The metalchelate complexes have relatively low biodegradability and induce negative influence to soil physico-chemical properties, soil biota and plant. Chelate-induced enhanced leaching of metals also checks its practical application in field. Soil microbial association helps plants to grow well, protect plants from the noxious effects of heavy metal(loid)s along with increased metal uptake by producing various substances. Use of genetically engineered plants equipped with useful remediation traits according to the requirements of contaminated sites can be highly effective tool to support this technology for on filed application. Transgenic approaches have successfully improved phytoextraction potential of hyperaccumulators mainly by the employment of metal transporters, and improved production of antioxidative enzymes and metal-detoxifying chelators. Moreover, judicial and environmentally safe application of chelating agents along with genetically engineered plants can further improve the effectiveness of this technique. In point of the fact, and since bioremediation generally addresses heterogeneous and multiphasic environment (soils), effective bioremediation depends on an interdisciplinary approach that integrates the work of soil chemists, plant biologist, geneticists, microbiologists, and environmental engineers.

This review revealed that cost involved, time required, long-term effectiveness, general acceptability, applicability to high metal and multimetal contaminated sites are the key factors that affect the applicability and selection of remediation technologies. The cost of heavy metal(loid) contaminated soil by phytoremediation can be minimized by gaining a better understanding of mechanisms/processes involved in remediation, and the various options available at different steps during remediation.

\section{References}

Abbas, G., Saqib, M., Akhtar, J., Murtaza, G., Shahid, M., Hussain, A., 2016. Relationship between rhizosphere acidification and phytoremediation in two acacia species. J. Soils Sediments 16, 1392-1399.

Abbas, G., Saqib, M., Akhtar, J., Murtaza, G., Shahid, M., 2015. Effect of salinity on rhizosphere acidification and antioxidant activity of two acacia species. Can. J. For. Res 45, 124-129.

Abou-Shanab, R.A.I., Angle, J.S., Chaney, R.L., 2006. Bacterial inoculants affecting nickel uptake by Alyssum murale from low, moderate and high Ni soils. Soil Biol. Biochem. 38 , 2882-2889.

Acosta, J.A., Arocena, J.M., Faz, A., 2015. Speciation of arsenic in bulk and rhizosphere soils from artisanal cooperative mines in Bolivia. Chemosphere 138, 1014-1020.

Adrees, M., Ali, S., Rizwan, M., Zia-ur-Rehman, M., Ibrahim, M., Abbas, F., Farid, M. Qayyum, M.F., Irshad, M.K., 2015. Mechanisms of silicon-mediated alleviation of heavy metal toxicity in plants: a review. Ecotoxicol. Environ. Saf. 119, 186-197.

Agnello, A.C., Bagard, M., van Hullebusch, E.D., Esposito, G., Huguenot, D., 2015. Comparative bioremediation of heavy metals and petroleum hydrocarbons co-contaminated soil by natural attenuation, phytoremediation, bioaugmentation and bioaugmentation-assisted phytoremediation. Sci. Total Environ. 564, 693-703.

Ahemad, M., 2014. Remediation of metalliferous soils through the heavy metal resistant plant growth promoting bacteria: Paradigms and prospects. Arab. J. Chem. http:// dx.doi.org/10.1016/j.arabjc.2014.11.020.

Ali, H., Khan, E., Sajad, M.A., 2013. Phytoremediation of heavy metals-concepts and applications. Chemosphere 91, 869-881.

Altinozlu, H., Karagoz, A., Polat, T., Unver, I., 2012. Nickel hyperaccumulation by natural plants in Turkish serpentine soils. Turk. J. Bot. 36, 269-280.

Al-Wabel, M.I., Usman, A.R.A., El-Naggar, A.H., Aly, A.A., Ibrahim, H.M., Elmaghraby, S., AlOmran, A., 2015. Conocarpus biochar as a soil amendment for reducing heavy metal availability and uptake by maize plants. Saudi J. Biol. Sci. 22, 503-511.

Anjos, C., Magalhães, M.C.F., Abreu, M.M., 2012. Metal (Al, Mn, Pb and Zn) soils extractable reagents for available fraction assessment, comparison using plants, and dry and moist soils from the Braçal abandoned lead mine area, Portugal. J. Geochem. Explor. $113,45-55$.

Anoduadi, C.O., Okenwa, L.B., Okieimen, F.E., Tyowua, A.T., Uwumarongie-Ilori, E.G., 2009. Metal immobilization in CCA contaminated soil using laterite and termite mound soil. Evaluation by chemical fractionation. Niger. J. Appl. Sci. 27, 77-87.

Arenas-Lago, D., Andrade, M.L., Vega, F.A., Singh, B.R., 2016. TOF-SIMS and FE-SEM/EDS to verify the heavy metal fractionation in serpentinite quarry soils. Catena 136, 30-43.

Arshad, M., Silvestre, J., Pinelli, E., Kallerhoff, J., Kaemmerer, M., Tarigo, A., Shahid, M. Guiresse, M., Pradere, P., Dumat, C., 2008. A field study of lead phytoextraction by various scented Pelargonium cultivars. Chemosphere 71, 2187-2192.

Ashraf, A., Bibi, I., Niazi, N.K., Ok, Y.S., Murtaza, G., Shahid, M., Kunhikrishnan, A Mahmood, T., 2016. Chromium(VI) immobilisation efficiency of acid-1 activated banana peel over organo-montmorillonite in aquatic environments. Int J. Phytoremediation http://dx.doi.org/10.1080/15226514.2016.1256372. 
ATSDR, 2012. Agency for Toxic Substance and Disease Registry, U.S. toxicological profile for cadmium. Department of Health and Humans Services, Public Health Service, Centers for Disease Control, Atlanta, Georgia, USA.

Austruy, A., Shahid, M., Xiong, T., Castrec, M., Payre, V., Niazi, N.K., Sabir, M., Dumat, C. 2014. Mechanisms of metal-phosphates formation in the rhizosphere soils of pea and tomato: environmental and sanitary consequences. J. Soils Sediments 14 666-678

Avci, H., Deveci, T., 2013. Assessment of trace element concentrations in soil and plants from cropland irrigated with wastewater. Ecotoxicol. Environ. Saf. 98, 283-291.

Baldantoni, D., Morra, L., Zaccardelli, M., Alfani, A., 2016. Cadmium accumulation in leaves of leafy vegetables. Ecotoxicol. Environ. Saf. 123, 89-94.

Bañuelos, G.S., Mayland, H.F., 2000. Absorption and distribution of selenium in animals consuming canola grown for selenium phytoremediation. Ecotoxicol. Environ. Saf. $46,322-328$.

Barrameda-Medina, Y., Montesinos-Pereira, D., Romero, L., Ruiz, J.M., Blasco, B., 2014 Comparative study of the toxic effect of $\mathrm{Zn}$ in Lactuca sativa and Brassica oleraced plants: I. Growth, distribution, and accumulation of $\mathrm{Zn}$, and metabolism of carboxylates. Environ. Exp. Bot. 107, 98-104.

Baum, C., Hrynkiewicz, K., Leinweber, P., Meißner, R., 2006. Heavy-metal mobilization and uptake by mycorrhizal and nonmycorrhizal willows (Salix $\times$ dasyclados). J. Plant Nutr. Soil Sci. 169, 516-522.

Beesley, L., Inneh, O.S., Norton, G.J., Moreno-Jimenez, E., Pardo, T., Clemente, R., Dawson, J.J., 2014. Assessing the influence of compost and biochar amendments on the mobility and toxicity of metals and arsenic in a naturally contaminated mine soil. Environ. Pollut. 186, 195-202.

Bernd, N., Obrecht, J.M., Schluep, M., Schulin, R., Hansmann, W., Koppel, V., 2001. Elevated lead and zinc contents in remote alpine soils of the Swiss National Park. J. Environ. Qual. 30, 919-926.

Bertagnolli, C., Grishin, A., Vincent, T., Guibal, E., 2016. Recovering heavy metal ions from complex solutions using polyethylenimine derivatives encapsulated in alginate matrix. Ind. Eng. Chem. Res. 55, 2461-2470.

Bhargava, A., Carmona, F.F., Bhargava, M., Srivastava, S., 2012. Approaches for enhanced phytoextraction of heavy metals. J. Environ. Manage. 105, 103-120.

Bittsánszkya, A., Kfmives, T., Gullner, G., Gyulai, G., Kiss, J., Heszky, L., Radimszky, L. Rennenberg, H., 2005. Ability of transgenic poplars with elevated glutathione content to tolerate zinc $(2+)$ stress. Environ. Interact. 31, 251-254.

Blaylock, M.J., Huang, J.W., 2000. Phytoextraction of metals. Phytoremediation of Toxic Metals: Using Plants to Clean up the Environment, pp. 53-70.

Blaylock, M.J., Salt, D.E., Dushenkov, S., Zakharova, O., Gussman, C., Kapulnik, Y., Ensley, B.D., Raskin, I., 1997. Enhanced accumulation of Pb in Indian mustard by soil-applied chelating agents. Environ. Sci. Technol. 31, 860-865.

Bolan, N., Kunhikrishnan, A., Thangarajan, R., Kumpiene, J., Park, J., Makino, T., Kirkham, M.B., Scheckel, K., 2014. Remediation of heavy metal(loid)s contaminated soils - To mobilize or to immobilize? J. Hazard. Mater. 266, 141-166.

Bolan, N.S., Park, J.H., Robinson, B., Naidu, R., Huh, K.Y., 2011. Phytostabilization. A green approach to contaminant containment. Adv. Agron. 112, 145-204.

Bosiacki, M., Tyksiñski, W., 2009. Copper, Zinc, Iron and Manganese content in edible parts of some fresh vegetables sold on markets in Poznañ. J. Elem. 14, 13-22.

Braud, A., Jézéquel, K., Bazot, S., Lebeau, T., 2009. Enhanced phytoextraction of an agricultural $\mathrm{Cr}$ - and $\mathrm{Pb}$-contaminated soil by bioaugmentation with siderophore-producing bacteria. Chemosphere 74, 280-286.

Bressler, J.P., Olivi, L., Cheong, J.H., Kim, Y., Bannon, D., 2004. Divalent metal transporter in lead and cadmium transport. Ann. N. Y. Acad. Sci. 1012, 142-152.

Brooks, R.R., Lee, J., Reeves, R.D., Jaffre, T., 1977. Detection of nickeliferous rocks by analysis of herbarium specimens of indicator plants. J. Geochem. Explor. 7 49-57.

Buelt, J.L., Thompson, L.E., 1992. The in situ vitrification integrated program: focusing an innovative solution on environmental restoration needs (No. PNL-SA-20853; CONF-920851-88). Pacific Northwest Lab., Richland, WA (United States).

Buendía-González, L., Orozco-Villafuerte, J., Cruz-Sosa, F., Barrera-Díaz, C.E., VernonCarter, E.J., 2010. Prosopis laevigata a potential chromium (VI) and cadmium (II) hyperaccumulator desert plant. Bioresour. Technol. 101, 5862-5867.

Carvalho, D.R.M., dos Santos, J.A., Silva, J.A.S., do Prado, T.G., da Fonseca, A.F., Chaves, E.S Frescura, V.L.A., 2015. Determination of metals in Brazilian soils by inductively coupled plasma mass spectrometry. Environ. Monit. Assess. 187, 535.

Cay, S., Uyanik, A., Engin, M.S., 2016. EDTA supported phytoextraction of Cd from contaminated soil by four different ornamental plant species. Soil Sediment Contam. Int. J. http://dx.doi.org/10.1080/15320383.2016.1138448.

Cele, E.N., Maboeta, M., 2016. A greenhouse trial to investigate the ameliorative properties of biosolids and plants on physicochemical conditions of iron ore tailings: Implications for an iron ore mine site remediation. J. Environ. Manag. 165, 167-174.

Chaney, R.L., Brown, S.L., Li, Y.M., Angle, J.S., Stuczynski, T.I., Daniels, W.L. Henry, C.L. Siebielec, G., Malik, M., Ryan, J.A., Compton, H., 2002. Progress in risk assessment for soil metals, and in-situ remediation and phytoextraction of metals from hazardous contaminated soils. Proc. USEPA Conf. Phytoremediation: State of the Science, May 1-2, 2000, Boston, MA. USEPA, Washington, DC

Chaney, R.L., Chen, K.Y., Li, Y.M., Angle, J.S., Baker, A.J., 2008. Effects of calcium on nickel tolerance and accumulation in Alyssum species and cabbage grown in nutrient solution. Plant Soil 311 (1-2), 131-140.

Chaney, R.L., Broadhurst, C.L., Centofanti, T., 2010. Phytoremediation of SOIL TRACE ELEMents. Trace Elements in Soils, pp. 311-352.

Chao, W., Xiao-Chen, L., Li-Min, Z., Pei-Fang, W., Zhi-Yong, G., 2007. Pb, Cu, Zn and Ni concentrations in vegetables in relation to their extractable fractions in soils in suburban areas of Nanjing, China. Pol. J. Environ. Stud. 16, 199-207.

Chehregani, A., Malayeri, B.E., 2007. Removal of heavy metals by native accumulator plants. Int. J. Agric. Biol. 1560, 462-465.
Chen, R.Z., Yang, F., Xu, X., 2005. Study on the growth-promoting effect of recombinant yeast containing fish growth hormone on sea water fish. Fish. Res. 7, 49-51 (in Chinese).

Chiroma, T.M., Ebewele, R.O., Hymore, F.K., 2014. Comparative assessment of heavy meta levels in soil, vegetables and urban grey waste water used for irrigation in Yola and Kano. Int. Ref. J. Eng. Sci. 3, 1-9.

Clark, D.P., Pazdernik, N.J., 2015. Biotechnology: Applying the Genetic Revolution. Newnes.

Compant, S., Reiter, B., Sessitsch, A., Nowak, J., Clément, C., Barka, E.A., 2005. Endophytic colonization of Vitis vinifera L. by plant growth-promoting bacterium Burkholderia sp. strain PsJN. Appl. Environ. Microbiol. 71, 1685-1693.

Connolly, E.L., Fett, J.P., Guerinot, M.L., 2002. Expression of the IRT1 metal transporter is controlled by metals at the levels of transcript and protein accumulation. Plant Cell $14,1347-1357$

Cotter-Howells, J., Caporn, S., 1996. Remediation of contaminated land by formation of heavy metal phosphates. Appl. Geochem. 335-342.

Courbot, M., Diez, L., Ruotolo, R., Chalot, M., Leroy, P., 2004. Cadmium-responsive thiols in the ectomycorrhizal fungus Paxillus involutus. Appl. Environ. Microbiol. 70, $7413-7417$.

Cunningham, S.D., Ow, D.W., 1996. Promises and prospects of phytoremediation. Plant Physiol. 110, 715-719.

De Knecht, J.A., Van Dillen, M., Koevoets, P.L.M., Schat, H., Verkleij, J.A.C., Ernst, W.H.O., 1994. Phytochelatins in cadmium-sensitive and cadmium-tolerant Silene vulgaris. Plant Physiol. 104, 255-261.

Deesouza, M.P., Pilon-Smits, E.A.H., Terry, N., 2000. The physiology and biochemistry of seenium volatilization by plants. In: Raskin, I., Ensley, B.D. (Eds.), Phytoremediation of Toxic Metals: Using Plants to Clean up the Environment. Wiley, New York, pp. 171-190.

Dellisanti, 2016. In-field remediation of tons of heavy metal-rich waste by Joule heating vitrification. Int. J. Miner. Process. 93, 239-245.

Deram, A., Petit, D., Robinson, B., Brooks, R., Gregg, P., Halluwyn, C.V., 2000. Natural and induced heavy-metal accumulation by Arrhenatherum elatius: implications for phytoremediation. Commun. Soil Sci. Plant Anal. 31, 413-421.

Douay, F., Pruvot, C., Roussel, H., Ciesielski, H., Fourrier, H., Proix, N., Waterlot, C., 2008 Contamination of urban soils in an area of northern France polluted by dust emissions of two smelters. Water Air Soil Pollut. 188, 247-260.

Eapen, S., D'Souza, S.F., 2005. Prospects of genetic engineering of plants for phytoremediation of toxic metals. Biotechnol. Adv. 23, 97-114.

Ensink, J.H.J., Mahmood, T., Van Der Hoek, W., Raschid-Sally, L., Amerasinghe, F.P., 2004. A nationwide assessment of wastewater use in Pakistan: an obscure activity or a vitally important one? Water Policy 6, 197-206.

Ensley, B.D., 2000. Phytoremediation of Toxic Metals: Using Plants to Clean up the Environment. Wiley \& Sons.

European Environmental Agency (EEA), 2007. http://ec.europa.eu/environment/emas/ pdf/es_library/99_dk_european_environment_agency_08.pdf.

Evangelou, M.W.H.,Ebel, M., Schaeffer, A., 2007. Chelate assisted phytoextraction of heavy metals from soil. Effect, mechanism, toxicity, and fate of chelating agents. Chemosphere 68, 989-1003.

Farahat, E., Linderholm, H.W., 2015. The effect of long-term wastewater irrigation on accumulation and transfer of heavy metals in Cupressus sempervirens leaves and adjacent soils. Sci. Total Environ. 512-513, 1-7.

Ferraro, A., van Hullebusch, E.D., Huguenot, D., Fabbricino, M., Esposito, G., 2015. Application of an electrochemical treatment for EDDS soil washing solution regeneration and reuse in a multi-step soil washing process: case of a Cu contaminated soil. J. Environ. Manag. 163, 62-69.

Förstner, U., 1995. Non-linear release of metals from aquatic sediments. Biogeodynamics of Pollutants in Soils and Sediments. Springer, Berlin Heidelberg, pp. 247-307.

Foucault, Y., Lévêque, T., Xiong, T., Schreck, E., Austruy, A., Shahid, M., Dumat, C. 2013. Green manure plants for remediation of soils polluted by metals and metalloids: ecotoxicity and human bioavailability assessment. Chemosphere 93 . $1430-1435$

Fuentes, I.I., Espadas-Gil, F., Talavera-May, C., Fuentes, G., Santamara, J.M., 2014. Capacity of the aquatic fern (Salvinia minima Baker) to accumulate high concentrations of nickel in its tissues, and its effect on plant physiological processes. Aquat. Toxicol. $155,142-150$

Fuge, R., Glover, S.P., Pearce, N.J., Perkins, W.T., 1991. Some observations on heavy metal concentrations in soils of the Mendip region of north Somerset. Environ. Geochem. Health 13 (4), 193-196.

Gadd, G.M., 2000. Bioremedial potential of microbial mechanisms of metal mobilization and immobilization. Curr. Opin. Biotechnol. 11, 271-279.

Gadd, G.M., 2010. Metals, minerals and microbes: Geomicrobiology and bioremediation. Microbiol. 156, 609-643.

Galende, M.A., Becerril, J.M., Barrutia, O., Artetxe, U., Garbisu, C., Hernández, A., 2014 Field assessment of the effectiveness of organic amendments for aided phytostabilization of a Pb-Zn contaminated mine soil. J. Geochem. Explor. 145, 181-189.

Garcia-Salgado, S., Raber, G., Raml, R., Magnes, C., Francesconi, K.A., 2012. Arsenosuga phospholipids and arsenic hydrocarbons in two species of brown macroalgae. Environ. Chem. 9, 63-66.

Ghosh, M., Singh, S.P., 2005. A review on phytoremediation of heavy metals and utilization of its byproducts. Appl. Ecol. Environ. Res. 6, 214-231.

Gisbert, C., Ros, R., De Haro, A., Walker, D.J., Bernal, M.P., Serrano, R., Navarro-Avic, J., 2003. A plant genetically modified that accumulates $\mathrm{Pb}$ is especially promising for phytoremediation. Biochem. Biophys. Res. Commun. 303, 440-445.

Goix, S., Leveque, T., Xiong, T.T., Schreck, E., Baeza-Squiban, A., Geret, F., Uzu, G., Austruy, A., Dumat, C., 2014. Environmental and health impacts of fine and ultrafine metallic particles: assessment of threat scores. Environ. Res. 133, 185-194.

Gorospe, J., 2012. Growing Greens and Soiled Soil: Trends in Heavy Metal Contamination in Vegetable Gardens of San Francisco. 
Grispen, V.M.J., Irtelli, B., Hakvoort, H.W.J., Vooijs, R., Bliek, T., ten Bookum, W.M., Verkleij, J.A.C., Schat, H., 2009. Expression of the Arabidopsis metallothionein $2 \mathrm{~b}$ enhances arsenite sensitivity and root to shoot translocation in tobacco. Environ. Exp. Bot. 66, 69-73.

Guo, G., Wu, F., Xie, F., Zhang, R., 2012. Spatial distribution and pollution assessment of heavy metals in urban soils from southwest China. J. Environ. Sci. 24, 410-418.

Guo, X., Wei, Z., Wu, Q., Li, C., Qian, T., Zheng, W., 2016. Effect of soil washing with only chelators or combining with ferric chloride on soil heavy metal removal and phytoavailability: field experiments. Chemosphere 147, 412-419.

Gupta, S., Jena, V., Jena, S., Davić, N., Matić, N., Radojević, D., Solanki, J.S., 2013. Assessment of heavy metal contents of green leafy vegetables. Croatian J. Food Sci. Technol. 5 (2), 53-60.

Han, W., Fu, F., Cheng, Z., Tang, B., Wu, S., 2016. Studies on the optimum conditions using acid-washed zero-valent iron/aluminum mixtures in permeable reactive barriers for the removal of different heavy metal ions from wastewater. J. Hazard. Mater. 302 , 437-446.

Hanson, A., David, T., Sabatin, A., 1992. Transport and Remediation of Subsurface Contaminants. American Chemical Society, Washington DC, USA, pp. 108-120.

He, J., Chen, J.P., 2014. A comprehensive review on biosorption of heavy metals by algal biomass: materials, performances, chemistry, and modeling simulation tools. Bioresour. Technol. 160, 67-78.

He, Z., Shen, J., Ni, Z., Tang, J., Song, S., Chen, J., Zhao, L., 2015. Electrochemically created roughened lead plate for electrochemical reduction of aqueous $\mathrm{CO}_{2}$. Catal. Commun. $72,38-42$.

Hediji, H., Djebali, W., Belkadhi, A., Cabasson, C., Moing, A., Rolin, D., Brouquisse, R., Gallusci, P., Chaebi, W., 2015. Impact of long-term cadmium exposure on mineral content of Solamum lycopersicum plants: consequences on fruit production. South African J. Bot. 97, 176-181.

Hongbo, S., Liye, C., Gang, X., Kun, Y., Lihua, Z., Junna, S., 2011. Progress in phytoremediating heavy-metal contaminated soils. Detoxification of Heavy Metals. Springer, Berlin Heidelberg, pp. 73-90.

Hou, Y., Gao, S., 2003. Monodisperse nickel nanoparticles prepared from a monosurfactant system and their magnetic properties. J. Mater. Chem. 13, 1510-1512.

Hu, P.J., Qiu, R.L., Senthilkumar, P., Jiang, D., Chen, Z.W., Tang, Y.T., Liu, F.J., 2009. Tolerance, accumulation and distribution of zinc and cadmium in hyperaccumulator Potentilla griffithii. Environ. Exp. Bot. 66, 317-325.

Hu, T., Zhu, S., Tan, L., Qi, W., He, S., Wang, G., 2016. Overexpression of OsLEA4 enhances drought, high salt and heavy metal stress tolerance in transgenic rice (Oryza sativa L.). Environ. Exp. Bot. 123, 68-77.

Iannelli, R., Masi, M., Ceccarini, A., Ostuni, M.B., Lageman, R., Muntoni, A., Spiga, D., Polettini, A., Marini, A., Pomi, R., 2015. Electrokinetic remediation of metal-polluted marine sediments: experimental investigation for plant design. Electrochim. Acta $181,146-159$.

Jarup, L., 2003. Hazards of heavy metal contamination. Br. Med. Bull. 68, 167-182.

Jensen, J.K., Holm, P.E., Nejrup, J., Larsen, M.B., Borggaard, O.K., 2009. The potential of willow for remediation of heavy metal polluted calcareous urban soils. Environ. Pollut 157, 931-937.

Kalve, S., Sarangi, B.K., Pandey, R.A., Chakrabarti, T., 2011. Arsenic and chromium hyperaccumulation by an ecotype of Pteris vittata prospective for phytoextraction from contaminated water and soil. Curr. Sci. 100 (6), 888-894.

Kang, Z., Yan, X., Wang, Y., Bai, Z., Liu, Y., Zhang, Z., Lin, P., Zhang, X., Yuan, H., Zhang, X., Zhang, Y., 2015. Electronic structure engineering of Cu2O film/ZnO nanorods array all-oxide p-n heterostructure for enhanced photoelectrochemical property and selfpowered biosensing application. Sci. Rep. 5, 7882.

Keller, C., Hammer, D., 2004. Metal availability and soil toxicity after repeated croppings of Thlaspi caerulescens in metal contaminated soils. Environ. Pollut. 131, 243-254.

Khan, M.A., Chattha, M.R., Farooq, K., Jawed, M.A., Farooq, M., Imran, M., Iftkhar, M., Kasana, M.I., 2015. Effect of farmyard manure levels and NPK applications on the pea plant growth, pod yield and quality. Life Sci. Int. J. 9, 3178-3181.

Khan, M.U., Malik, R.N., Muhammad, S., 2013. Human health risk from heavy metal via food crops consumption with wastewater irrigation practices in Pakistan. Chemosphere 93, 2230-2238.

Khoudi, H., Maatar, Y., Brini, F., Fourati, A., Ammar, N., Masmoudi, K., 2013. Phytoremediation potential of Arabidopsis thaliana, expressing ectopically a vacuolar proton pump, for the industrial waste phosphogypsum. Environ. Sci. Pollut. Res. 20, $270-280$.

Kinoshita, H., Swift, P., Utton, C., Carro-Mateo, B., Marchand, G., Collier, N., Milestone, N., 2013. Corrosion of aluminium metal in OPC- and CAC-based cement matrices. Cem. Concr. Res. 50, 11-18.

Koptsik, G.N., 2014. Problems and prospects concerning the phytoremediation of heavy metal polluted soils: a review. Eurasian Soil Sci. 47, 923-939.

Kotrba, P., Najmanova, J., Macek, T., Ruml, T., Mackova, M., 2009. Genetically modified plants in phytoremediation of heavy metal and metalloid soil and sediment pollution. Biotechnol. Adv. 27, 799-810.

Kuang, Y., Du, J., Zhou, R., Chen, Z., Megharaj, M., Naidu, R., 2015. Calcium alginate encapsulated $\mathrm{Ni} / \mathrm{Fe}$ nanoparticles beads for simultaneous removal of $\mathrm{Cu}$ (II) and monochlorobenzene. J. Colloid Interface Sci. 447, 85-91.

Kucharski, R., Sas-Nowosielska, A., Małkowski, E., Japenga, J., Kuperberg, J.M., Pogrzeba, M., Krzyzak, J., 2005. The use of indigenous plant species and calcium phosphate for the stabilization of highly metal-polluted sites in southern Poland. Plant Soil 273. 291-305.

Kulikowska, D., Gusiatin, Z.M., Bulkowska, K., Klik, B., 2015. Feasibility of using humic substances from compost to remove heavy metals ( $\mathrm{Cd}, \mathrm{Cu}, \mathrm{Ni}, \mathrm{Pb}, \mathrm{Zn}$ ) from contaminated soil aged for different periods of time. J. Hazard. Mater. 300, 882-891.
Kumar, N., Bauddh, K. Kumar, S, Dwivedi, N., Singh, D.P., Barman, S.C., 2013. Accumulation of metals in weed species grown on the soil contaminated with industrial waste and their phytoremediation potential. Ecol. Eng. 61, 491-495.

Küpper, H., Lombi, E., Zhao, F.J., McGrath, S.P., 2000. Cellular compartmentation of cadmium and zinc in relation to other elements in the hyperaccumulator Arabidopsis halleri. Planta 212 (1), 75-84.

Kwon, M.S., Yu, Y., Coburn, C., Phillips, A.W., Chung, K., Shanker, A., Jung, J., Kim, G., Pipe, K., Forrest, S.R., Youk, J.H., Gierschner, J., Kim, J., 2015. Suppressing molecular motions for enhanced room-temperature phosphorescence of metal-free organic materials. Nat. Commun. 6, 8947

Lee, S.H., Ji, W., Lee, W.S., Koo, N., Koh, I.H., Kim, M.S., Park, J.S., 2014. Influence of amendments and aided phytostabilization on metal availability and mobility in $\mathrm{Pb} / \mathrm{Zn}$ mine tailings. J. Environ. Manag. 139, 15-21.

Lee, J.Y., Kwon, T.S., Park, J.Y., Choi, S., Kim, E.J., Lee, H.U., Lee, Y.C., 2016. Electrokinetic (EK) removal of soil co-contaminated with petroleum oils and heavy metals in three-dimensional (3D) small-scale reactor. Process Saf. Environ. Prot. 99 186-193.

Lee, S., Moon, J.S., Ko, T.-S., Petros, D., Goldsbrough, P.B., Korban, S.S., 2003. Overexpression of Arabidopsis phytochelatin synthase paradoxically leads to hypersensitivity to cadmium stress. Plant Physiol. 131, 656-663.

Lestan, D., Luo, C., Ling, L., Dong, X., 2008. The use of chelating agents in the remediation of metal-contaminated soils: a review. Environ. Pollut. 153, 3-13.

Lewandowski, I., Schmidt, U., Londo, M., Faaij, A., 2006. The economic value of the phytoremediation function - assessed by the example of cadmium remediation by willow (Salix ssp). Agric. Syst. 89, 68-89.

Li, Y.M., Chaney, R., Brewer, E., Roseberg, R., Angle, J.S., Baker, A., Nelkin, J., 2003. Development of a technology for commercial phytoextraction of nickel: economic and technical considerations. Plant Soil 249 (1), 107-115.

Liao, X. Li, Y. Yan, X., 2015. Removal of heavy metals and arsenic from a co-contaminated soil by sieving combined with washing process. J. Environ. Sci. 1-9.

Liu, C.Y., Gong, X.F., Tang, Y.P., Chen, C.L., 2015. Lead sequestration in iron plaques developed on Phalaris arundinacea Linn. and Carex cinerascens Kukenth. from Poyang Lake (China). Aquat. Bot. 122, 54-59.

Liu, X., Huang, B., Lin, J., Fei, J., Chen, Z., Pang, Y., Sun, X., Tang, K., 2006. A novel pathogenesis-related protein (SsPR10) from Solanum surattense with ribonucleolytic and antimicrobial activity is stress- and pathogen-inducible. J. Plant Physiol. $163,546-556$

Liu, Z., He, X., Chen, W., Yuan, F., Yan, K., Tao, D., 2009. Accumulation and tolerance characteristics of cadmium in a potential hyperaccumulator Lonicera japonica Thunb. J. Hazard. Mater. 169, 170-175.

Lloyd, J.R., 2002. Bioremediation of metals; the application of micro-organisms that make and break minerals. Interact. 29, 67-69.

Lombi, E., Zhao, F.J., Dunham, S.J., McGrath, S.P., 2001. Phytoremediation of heavy metalcontaminated soils. J. Environ. Qual. 30 (6), 1919-1926.

Luo, S., Lian, C., Chen, L., Liang, J., Xiao, X., Xu, T., Ying, W., Rao, Y., Liu, C., Bin, C., Liu, Y., Tang, L., Zeng, C., Ming, G., 2011. Analysis and characterization of cultivable heavy metal-resistant bacterial endophytes isolated from Cd-hyperaccumulato Solanum nigrum L. and their potential use for phytoremediation. Chemosphere $85,1130-1138$.

Ma, J.F., Goto, S., Tamai, K., Ichii, M., 2001. Role of root hairs and lateral roots in silicon uptake by rice. Plant Physiol. 127, 1773-1780.

Ma, J.F., Yamaji, N., Mitani, N., Xu, X.Y., Su, Y.H., McGrath, S.P., Zhao, F.J., 2008. Transporters of arsenite in rice and their role in arsenic accumulation in rice grain. Proceedings of the National Academy of Sciences 105, 9931-9935

Ma, Y., Oliveira, R.S., Nai, F., Rajkumar, M., Luo, Y., Rocha, I., Freitas, H., 2015. The hyperaccumulator sedum plumbizincicola harbors metal-resistant endophytic bacteria that improve its phytoextraction capacity in multi-metal contaminated soil. J. Environ. Manag. 156, 62-69.

Mahar, A., Wang, P., Ali, A., Kumar, M., Hussain, A., Wang, Q., Li, R., Zhang, Z., 2016. Challenges and opportunities in the phytoremediation of heavy metals contaminated soils: a review. Ecotoxicol. Environ. Saf. 126, 111-121.

Makino, T., Takano, H., Kamiya, T., Itou, T., Sekiya, N., Inahara, M., Sakurai, Y., 2008. Restoration of cadmium-contaminated paddy soils by washing with ferric chloride: Cd extraction mechanism and bench-scale verification. Chemosphere 70 $1035-1043$

Mallampati, S.R., Mitoma, Y., Okuda, T., Simion, C., Lee, B.K., 2015. Dynamic immobilization of simulated radionuclide $133 \mathrm{Cs}$ in soil by thermal treatment/vitrification with nanometallic $\mathrm{Ca} / \mathrm{CaO}$ composites. J. Environ. Radioact. 139, 118-124.

Mao, X., Han, F.X., Shao, X., Guo, K., McComb, J., Arslan, Z., Zhang, Z., 2016. Electro-kinetic remediation coupled with phytoremediation to remove lead, arsenic and cesium from contaminated paddy soil. Ecotoxicol. Environ. Saf. 125, 16-24.

Mapanda, F., Mangwayana, E.N., Nyamangara, J., Giller, K.E., 2007. Uptake of heavy metals by vegetables irrigated using wastewater and the subsequent risks in Harare, Zimbabwe. Phys. Chem. Earth 32, 1399-1405.

Marabottini, R., Stazi, S.R., Papp, R., Grego, S., Moscatelli, M.C., 2013. Mobility and distribution of arsenic in contaminated mine soils and its effects on the microbial pool. Ecotoxicol. Environ. Saf. 96, 147-153.

Marques, A.P.G.C., Oliveira, R.S., Samardjieva, K.A., Pissarra, J., Rangel, A.O.S.S., Castro, P.M.L., 2007. Solanum nigrum grown in contaminated soil: effect of arbuscular mycorrhizal fungi on zinc accumulation and histolocalisation. Environ. Pollut. 145, 691-699.

Marques, A.P.G.C., Rangel, A.O.S.S., Castro, P.M.L., 2009. Remediation of heavy metal contaminated soils: phytoremediation as a potentially promising clean-up technology. Crit. Rev. Environ. Sci. Technol. 39, 622-654.

Meagher, R.B., 2000. Phytoremediation of toxic elemental and organic pollutants. Curr. Opin. Plant Biol. 3, 153-162. 
Meers, E., Van Slycken, S., Adriaensen, K., Ruttens, A., Vangronsveld, J., Du Laing, G., Tack, F.M.G., 2010. The use of bio-energy crops (Zea mays) for 'phytoattenuation' of heavy metals on moderately contaminated soils: a field experiment. Chemosphere 78 (1) $35-41$.

Memon, A.R., Schröder, P., 2009. Implications of metal accumulation mechanisms to phytoremediation. Environ. Sci. Pollut. Res. 16, 162-175.

Mench, M., Baize, D., 2004. Contamination Des Sols Et De Nos Aliments D'Origine Végétale Par Les Éléments En Traces. Courr. l'environnement l'INRA 52, 31-56.

Mench, M., Martin, E., 1991. Mobilization of cadmium and other metals from two soils by root exudates of Zea mays L., Nicotiana tabacum L. and Nicotiana rustica L. Plant Soil 132, 187-196.

Mesjasz-Przybyłowics, J., Nakonieczny, M., Migula, P., Augustyniak, M., Tarnawska, M., Reimold, W.U., Koeberl, C., Przybyłowicz, W., Głowacka, E., 2004. Uptake of cadmium, lead, nickel and zinc from soil and water solutions by the nickel hyperaccumulator berkheya coddii. Acta Biol. Cracov. Bot. 46, 75-85.

Minnikova, T.V., Denisova, T.V., Mandzhieva, S.S., Kolesnikov, S.I., Minkina, T.M. Chaplygin, V.A., Burachevskaya, M.V., Sushkova, S.N., Bauer, T.V., 2017 Assessing the effect of heavy metals from the Novocherkassk power station emissions on the biological activity of soils in the adjacent areas. J. Geochem. Explor. 174, 70-78.

Mombo, S., Foucault, Y., Deola, F., Gaillard, I., Goix, S., Shahid, M., Schreck, E., Pierart, A Dumat, C., 2015. Management of human health risk in the context of kitchen gardens polluted by lead and cadmium near a lead recycling company. J. Soils Sediments 16 $1214-1224$.

Mulligan, C.N., Yong, R.N., Gibbs, B.F., 2001. Remediation technologies for metal-contaminated soils and groundwater: an evaluation. Eng. Geol. 60, 193-207.

Murtaza, G., Murtaza, B., Niazi, K.N., Sabir, M., Ahmad, P., Wani, R.M., Azooz, M.M., Phan Tran, L.-S., 2014. Soil contaminants: sources, effects, and approaches for remediation. Improvement of Crops in the Era of Climatic Changes. 2, pp. 171-196.

Myoung Soo Ko, M.S., Kim, J.Y., Park, H.S., Kim, K.W., 2015. Field assessment of arsenic immobilization in soil amended with iron rich acid mine drainage sludge. J. Clean. Prod. $108,1073-1080$

Nabulo, G., Black, C.R., Craigon, J., Young, S.D., 2012. Does consumption of leafy vegetables grown in peri-urban agriculture pose a risk to human health? Environ. Pollut. 162 389-398

Nabulo, G., Black, C.R., Young, S.D., 2011. Trace metal uptake by tropical vegetables grown on soil amended with urban sewage sludge. Environ. Pollut. 159, 368-376.

Nandakumar, P.B.A., Dushenkov, V., Motto, H., Raskin, I., 1995. Phytoextraction: the use of plants to remove heavy metals from soils. Environ. Sci. Technol. 29, $1232-1238$

Naser, H.M., Mahmud, N.U., Sultana, S., Gomes, R., Rahman, M., 2012. Trace elements content in vegetables grown in industrially polluted and non-polluted areas. Bangladesh J. Agric. Res. 37, 515-527.

Navarro, A., Cardellach, E., Cañadas, I., Rodríguez, J., 2013. Solar thermal vitrification of mining contaminated soils. Int. J. Miner. Process. 119, 65-74.

Neuhieral, B., Thanbichler, M., Lottspeich, F., Bock, A., 1999. A family of S methylmethionine dependent thiol/selenol methyltransferases. J. Biol. Chem. 274, 5407-5414.

Niazi, N.K., Murtaza, B., Bibi, I., Shahid, M., White, J.C., Nawaz, M.F., Bashir, S., Murtaza, G., 2016b. Removal and recovery of metals by biosorbents and biochars derived from biowastes. Environmental Materials and Waste: Resource Recovery and Pollution Prevention http://dx.doi.org/10.1016/B978-0-12-803837-6.00007-X.

Niazi, N.K., Bashir, S., Bibi, I., Murtaza, B., Shahid, M., Javed, M.T., Shakoor, M.B., Saqib, Z.A Nawaz, M.F., Aslam, Z., Wang, H., Murtaza, G., 2016a. Phytoremediation of arseniccontaminated soils using arsenic hyperaccumulating ferns. In: Ansari, et al. (Eds.) Phytoremediation, pp. 521-545.

Niazi, N.K., 2011. Variability, Speciation and Phytoremediation of Soil Arsenic at Cattle Dip Sites in NSW, Australia.

Niazi, N.K., Singh, B., Minasny, B., 2015. Mid-infrared spectroscopy and partial leastsquares regression to estimate soil arsenic at a highly variable arsenic-contaminated site. Int. J. Environ. Sci. Tech. 12 (6), 1965-1974.

Niazi, N.K., Bishop, T.F.A., Singh, B., 2011. Evaluation of spatial variability of soil arsenic ad jacent to a disused cattle-dip site, using model-based geostatistics. Environ. Sci. Technol. 45, 10463-10470.

Niu, L.Q., Jia, P., Li, S.P., Kuang, J.L., He, X.X., Zhou, W.H., Li, J.T., 2015. Slash-and-char, an ancient agricultural technique holds new promise for management of soils contaminated by $\mathrm{Cd}, \mathrm{Pb}$ and $\mathrm{Zn}$. Environ. Pollut. 205, 333-339.

Obiora, S.C., Chukwu, A., Davies, T.C., 2016. Heavy metals and health risk assessment of arable soils and food crops around $\mathrm{Pb}$ e Zn mining localities in Enyigba, southeastern Nigeria. J. African Earth Sci. 116, 182-189.

Ovečka, M., Takáč, T., 2014. Managing heavy metal toxicity stress in plants: biological and biotechnological tools. Biotechnol. Adv, 32, 73-86.

Page, M.M., Page, C.L., 2002. Electroremediation of contaminated soils. J. Environ. Eng. $128,208-219$

Panagopoulos, I., Karayannis, A., Kollias, K., Xenidis, A., Papassiopi, N., 2015. Investigation of potential soil contamination with $\mathrm{Cr}$ and $\mathrm{Ni}$ in four metal finishing facilities at Asopos industrial area. J. Hazard. Mater. 281, 20-26.

Pandey, B., Kinrade, S.D., Catalan, L.J.J., 2012. Effects of carbonation on the leachability and compressive strength of cement-solidified and geopolymer-solidified synthetic metal wastes. J. Environ. Manag. 101, 59-67.

Park, B., Son, Y., 2016. Ultrasonic and mechanical soil washing processes for the removal of heavy metals from soils. Ultrasonics Sonochemistry.

Park, S.-J., Kim, S., Lee, S., Khim, Z.G., Char, K., Hyeon, T., 2000. Synthesis and magnetic studies of uniform iron nanorods and nanospheres. J. Am. Chem. Soc. 122 8581-8582.
Parra, A., Zornoza, R., Conesa, E., Gómez-López, M.D., Faz, A., 2016. Evaluation of the suitability of three Mediterranean shrub species for phytostabilization of pyritic mine soils. Catena 136, 59-65.

Pattnaik, B.K., Equeenuddin, S.M., 2016. Potentially toxic metal contamination and enzyme activities in soil around chromite mines at Sukinda ultramafic complex, India. Geochem. Explor. 168, 127-136.

Peng, L., Chen, X., Zhang, Y., Du, Y., Huang, M., Wang, J., 2015. Remediation of metal contamination by electrokinetics coupled with electrospun polyacrylonitrile nanofiber membrane. Process. Saf. Environ. Prot. 98, 1-10.

Peplow, D., 1999. Environmental Impacts of Mining in Eastern Washington. University of Washington Water Center.

Pereira, B.F.F., Rozane, D.E., Araujo, S.R., Barth, G., Queiroz, R.J.B., Nogueira, T.A.R., Moraes, M.F., Cabral, C.P., Boaretto, A.E., Malavolta, E., 2011. Cadmium availability and accumulation by lettuce and rice. Rev. Bras. Ciênc. Solo 35, 645-654.

Perez, J., 2012. The Soil Remediation Industry in Europe: The Recent Past and Future Perspectives. http://ec.europa.eu/environment/archives/soil/pdf/may2012/08\%20-\% 20Julien\%20Perez\%20-\%20final.pdf.

Perveen, S., Samad, A., Nazif, W., Shah, S., 2012. Impact of sewage water on vegetables quality with respect to heavy metals in Peshawar Pakistan. Pak. J. Bot. 44 1923-1931.

Pierart, A., Shahid, M., Séjalon-Delmas, N., Dumat, C., 2015. Antimony bioavailability: Knowledge and research perspectives for sustainable agricultures. J. Hazard. Mater 289, 219-234.

Pourrut, B., Jean, S., Silvestre, J., Pinelli, E., 2011a. Lead-induced DNA damage in Vicia faba root cells: potential involvement of oxidative stress. Mutat. Res. 726, 123-128.

Pourrut, B., Perchet, G., Silvestre, J., Cecchi, M., Guiresse, M., Pinelli, E., 2008. Potential role of NADPH-oxidase in early steps of lead-induced oxidative burst in Vicia faba roots. J. Plant Physiol. 165, 571-579.

Pourrut, B., Shahid, M., Douay, F., Dumat, C., Pinelli, E., 2013. Molecular mechanisms in volved in lead uptake, toxicity and detoxification in higher plants. In: Gupta, D.K. (Ed.), Heavy Metal Stress in Plants. Springer-Verlag, Berlin.

Pourrut, B., Shahid, M., Dumat, C., Winterton, P., Pinelli, E., 2011b. Lead uptake, toxicity, and detoxification in plants. Rev. Environ. Contam. Toxicol. 213, 113-136.

Prasad, M.N.V. 2005. Nickelophilous plants and their significance in phytotechnologies. Braz. J. Plant Physiol. 17, 113-128.

Puga, A.P., Abreu, C.A., Melo, L.C.A., Beesley, L., 2015. Biochar application to a contaminated soil reduces the availability and plant uptake of zinc, lead and cadmium. J. Environ. Manag. 159, 86-93.

Qin, C., Li, H., Xiao, Q., Liu, Y., Zhu, J., Du, Y., 2006. Water-solubility of chitosan and its antimicrobial activity. Carbohydr. Polym. 63, 367-374

Quezada-hinojosa, R., Föllmi, K.B., Gillet, F., Matera, V., 2015. Cadmium accumulation in six common plant species associated with soils containing high geogenic cadmium concentrations at Le Gurnigel, Swiss Jura Mountains EX. Catena 124, $85-96$.

Rajkumar, M., Prasad, M.N.V., Swaminathan, S., Freitas, H., 2013. Climate change driven plant-metal-microbe interactions. Environ. Int. 53, 74-86.

Rajkumar, M., Sandhya, S., Prasad, M.N.V., Freitas, H., 2012. Perspectives of plant-associated microbes in heavy metal phytoremediation. Biotechnol. Adv. 30, 1562-1574.

Ramesh, G., Podila, G.K., Gay, G., Marmeisse, R., Reddy, M.S., 2009. Different patterns of regulation for the copper and cadmium metallothioneins of the ectomycorrhizal fungus Hebeloma cylindrosporum. Appl. Environ. Microbiol. 75, 2266-2274.

Rashid, M.I., Shahzad, T., Shahid, M., Basahi, J.M., Almeelbi, T., 2017. Zinc oxide nanoparticles affect carbon and nitrogen mineralization of Phoenix dactylifera leaf litter in a sandy soil. J. Hazard. Mater. B. 324, 298-305.

Rascio, N., Navari-Izzo, F., 2011. Heavy metal hyperaccumulating plants: how and why do they do it? And what makes them so interesting? Plant Sci. 180, 168-181.

Renna, M., Cocozza, C., Gonnella, M., Abdelrahman, H. Santamaria, P. 2015. Elemental characterization of wild edible plants from countryside and urban areas. Food Chem. 177, 29-36.

Rosestolato, D., Bagatin, R., Ferro, S., 2015. Electrokinetic remediation of soils polluted by heavy metals (mercury in particular). Chem. Eng. J. 264, 16-23.

Ross, S.M., 1994. Sources and Forms of potentially Toxic Metals in Soil-Plant Systems.

Rozas, F., Castellote, M., 2012. Electrokinetic remediation of dredged sediments polluted with heavy metals with different enhancing electrolytes. Electrochim. Acta 102-109.

Rugh, C.L., Bizily, S.P., Meagher, R.B., 2000. Phytoremediation of environmental mercury pollution. In: Raskin, I., Ensley, B.D. (Eds.), Phytoremediation of Toxic Metals Using Plants to Clean up the Environment. Wiley, New York, pp. 151-171.

Rugh, C.L., Senecoff, J.F., Meagher, R.B., Merkle, S.A., 1998. Development of transgenic yellow poplar for mercury phytoremediation. Nat. Biotechnol. 16, 925-928.

Rugh, C.L., Wilde, H.D., Stack, N.M., Thompson, D.M., Summers, A.O., Meagher, R.B., 1996. Mercuric ion reduction and resistance in transgenic Arabidopsis thaliana plants expressing a modified bacterial merA gene. Proc. Natl. Acad. Sci. U. S. A. 93, 3182-3187.

Rumer, R.R., Ryan, M.E., 1995. Barrier Containment Technologies for Environmental Remediation Applications. Wiley-Interscience.

Sabir, M., Waraich, E.A., Hakeem, K.R., Öztürk, M., Ahmad, H.R., Shahid, M. 2015 Phytoremediation, Soil Remediation and Plants. Elsevier Inc. http://dx.doi.org/10. 1016/B978-0-12-799937-1.00004-8.

Sacristán, D., Rossel, R.A.V., Recatalá, L., 2016. Proximal sensing of Cu in soil and lettuce using portable X-ray fluorescence spectrometry. Geoderma 265, 6-11.

Saifullah, Meers, E., Oadir, M., de Caritat, P., Tack, F.M.G., Du Laing, G., Zia, M.H., 2009. EDTA-assisted Pb phytoextraction. Chemosphere 74, 1279-1291.

Saifullah, Shahid, M., Zia-Ur-Rehman, M., Sabir, M., Ahmad, H.R., 2015. Phytoremediation of Pb-contaminated soils using synthetic chelates. Soil Remediation and Plants. Elsevier Inc. 
Sakakibara, M., Ohmori, Y., Ha, N.T.H., Sano, S., Sera, K., 2011. Phytoremediation of heavy metal-contaminated water and sediment by Eleocharis acicularis. Clean: Soil, Air, Water 39, 735-741.

Sakakibara, M., Watanabe, A., Inoue, M., Sano, S., Kaise, T., 2010. Phytoextraction and phytovolatilization of arsenic from As-contaminated soils by Pteris vittata. Proceedings of the Annual International Conference on Soils, Sediments, Water and Energy. 12, p. 26.

Salt, D.E., Blaylock, M., Kumar, N.P.B.A., Dushenkov, V., Ensley, B.D., Chet, I., Raskin, I., 1995. Phytoremediation: a novel strategy for the removal of toxic metals from the environment using plants. Bio/Technology 13, 468-474.

Santos-Jallath, J., Castro-Rodríguez, A., Huezo-Casillas, J., Torres-Bustillos, L., 2012. Arsenic and heavy metals in native plants at tailings impoundments in Queretaro. Mexico. Phys. Chem. Earth 37-39, 10-17.

Saravanan, V.S., Madhaiyan, M., Thangaraju, M., 2007. Solubilization of zinc compounds by the diazotrophic, plant growth promoting bacterium Gluconacetobacter diazotrophicus. Chemosphere 66, 1794-1798.

Schlecht, M.T., Säumel, I., 2015. Wild growing mushrooms for the Edible City? Cadmium and lead content in edible mushrooms harvested within the urban agglomeration of Berlin, Germany, Environ. Pollut 204, 298-305.

Schnoor, J.L., 1997. Phytoremediation. GWRTAC

Shaheen, S.M., Rinklebe, J., Rupp, H., Meissner, R., 2014. Temporal dynamics of pore water concentrations of $\mathrm{Cd}, \mathrm{Co}, \mathrm{Cu}, \mathrm{Ni}$, and $\mathrm{Zn}$ and their controlling factors in a contaminated floodplain soil assessed by undisturbed groundwater lysimeters. Environ. Pollut. 191, 223-231.

Shahid, M., Arshad, M., Kaemmerer, M., Pinelli, E., 2012b. Long-term field metal extraction by pelargonium: phytoextraction efficiency in relation to plant maturity. Int. J. Phytoremediation 14, 493-505.

Shahid, M., Austruy, A., Echevarria, G., Arshad, M., Sanaullah, M., Aslam, M., Nadeem, M., Nasim, W. Dumat, C. 2014e. EDTA-enhanced phytoremediation of heavy metals: a review. Soil Sediment Contam. Int. J. 23, 389-416.

Shahid, M., Dumat, C., Aslam, M., Pinelli, E., 2012d. Assessment of lead speciation by organic ligands using speciation models. Chem. Speciat. Bioavailab. 24, 248-252.

Shahid, M., Dumat, C., Khalid, S., Niazi, N.K., Antunes, P.M.C., 2016. Cadmium bioavailability, uptake, toxicity and detoxification in soil-plant system. Rev. Environ. Contam. Toxicol. 1-65.

Shahid, M., Dumat, C., Pourrut, B., Abbas, G., Shahid, N., Pinelli, E., 2015b. Role of metal speciation in lead-induced oxidative stress to Vicia faba roots. Russ. J. Plant Physiol. $62,448-454$

Shahid, M., Khalid, S., Abbas, G., Shahid, N., Nadeem, M., Sabir, M., Aslam, M., Dumat, C., 2015a. Heavy metal stress and crop productivity. In: Hakeem, K.R. (Ed.), Crop Production and Global Environmental Issues. Springer International Publishing, pp. 1-25.

Shahid, M., Dumat, C., Pourrut, B., Sabir, M., Pinelli, E., 2014b. Assessing the effect of metal speciation on lead toxicity to Vicia faba pigment contents. J. Geochem. Explor. 144, 290-297.

Shahid, M., Dumat, C., Pourrut, B., Silvestre, J., Laplanche, C., Pinelli, E., 2014g. Influence of EDTA and citric acid on lead-induced oxidative stress to Vicia faba roots. J. Soils Sediments 14, 835-843.

Shahid, M., Dumat, C., Silvestre, J., Pinelli, E., 2012c. Effect of fulvic acids on lead-induced oxidative stress to metal sensitive Vicia faba L. plant. Biol. Fertil. Soils 48, 689-697.

Shahid, M., Ferrand, E., Schreck, E., Dumat, C., 2013b. Behavior and impact of zirconium in the soil-plant system: plant uptake and phytotoxicity. Rev. Environ. Contam. Toxicol. $221,107-127$

Shahid, M., Pinelli, E., Dumat, C., 2012a. Review of Pb availability and toxicity to plants in relation with metal speciation; role of synthetic and natural organic ligands. J. Hazard. Mater. 219-220, 1-12.

Shahid, M., Pinelli, E., Pourrut, B., Dumat, C., 2014f. Effect of organic ligands on lead-induced oxidative damage and enhanced antioxidant defense in the leaves of Vicia faba plants. J. Geochem. Explor. 144, 282-289.

Shahid, M., Pinelli, E., Pourrut, B., Silvestre, J., Dumat, C., 2011. Lead-induced genotoxicity to Vicia faba L. roots in relation with metal cell uptake and initial speciation. Ecotoxicol. Environ. Saf. 74, 78-84.

Shahid, M., Pourrut, B., Dumat, C., Nadeem, M., Aslam, M., Pinelli, E., 2014a. Heavy-metalinduced reactive oxygen species: phytotoxicity and physicochemical changes in plants. Rev. Environ. Contam. Toxicol. 232, 1-44.

Shahid, M., Sabir, M., Ali, M.A., Ghafoor, A., 2014d. Effect of organic amendments on phytoavailability of nickel and growth of berseem (Trifolium alexandrinum) under nickel contaminated soil conditions. Chem. Speciat. Bioavailab. 26, 37-42.

Shahid, M., Xiong, T., Castrec-Rouelle, M., Leveque, T., Dumat, C., 2013a. Water extraction kinetics of metals, arsenic and dissolved organic carbon from industrial contaminated poplar leaves. J. Environ. Sci. (China) 25, 2451-2459.

Shahid, M. Xiong T, Masood, N. Leveque, T, Quenea, K. Austruy, A, Foucault, Y Dumat, C., 2014c. Influence of plant species and phosphorus amendments on metal speciation and bioavailability in a smelter impacted soil: a case study of food-chain contamination. J. Soil. Sediment. 14, 655-665.

Shakoor, M., Niazi, N., Bibi, I., Rahman, M., Naidu, R., Dong, Z., Shahid, M., Arshad, M., 2015. Unraveling health risk and speciation of arsenic from groundwater in rural areas of Punjab, Pakistan. Int. J. Environ. Res. Public Health 12, 12371-12390.

Shakoor, M., Niazi, N.K., Irshad, B., Murtaza, G., Kunhikrishnan, A., Seshadri, B., Shahid, M., Ali, S., Bolan, S., Yong, N., Muhammad Abid, S.O., Ali, F., 2016. Remediation of arseniccontaminated water using agricultural wastes as biosorbents. Crit. Rev. Environ. Sci. Technol. 46, 467-499.

Sheng, X.F., Xia, J.J., Jiang, C.Y., He, L.Y., Qian, M., 2008. Characterization of heavy metal-resistant endophytic bacteria from rape (Brassica napus) roots and their potential in promoting the growth and lead accumulation of rape. Environ. Pollut. 156 (3), $1164-1170$.
Sheoran, V., Sheoran, A.S., Poonia, P., 2016. Factors affecting phytoextraction: a review. Pedosphere 26 (2), 148-166.

Sheoran, V., Sheoran, A.S., Poonia, P., 2009. Phytomining: a review. Miner. Eng. 22, 1007-1019.

Shi, G.L. Zhu, S., Bai, S.N. Xia, Y., Lou, LQ Cai, Q.S. 2015. The transportation and accumulation of arsenic, cadmium, and phosphorus in 12 wheat cultivars and their relationships with each other. J. Hazard. Mater. 299, 94-102.

Shukla, D., Tiwari, M., Tripathi, R.D., Nath, P., Trivedi, P.K., 2013. Synthetic phytochelatins complement a phytochelatin-deficient Arabidopsis mutant and enhance the accumulation of heavy metal(loid)s. Biochem. Biophys. Res. Commun. 434, 664-669.

Smičiklas, I., Smiljanič, S., Perič-Grujič, A., Ljivič-Ivanovič, M., Mitrič, M., Antonovič, D., 2014. Effect of acid treatment on red mud properties with implications on $\mathrm{Ni}(\mathrm{II})$ sorption and stability. Chem. Eng. J. 242, 27-35.

Smith, E., Juhasz, A.L., Weber, J., Naidu, R., 2008. Arsenic uptake and speciation in rice plants grown under greenhouse conditions with arsenic contaminated irrigation water. Sci. Total Environ. 392, 277-283.

Smith, P.A., Vienna, J.D., Hrma, P., 1995. The effects of melting reactions on laboratoryscale waste vitrification. J. Matter. Res. 10 (08), 2137-2149.

Soares, M.A.R., Quina, M.J., Quinta-Ferreira, R.M., 2015. Immobilisation of lead and zinc in contaminated soil using compost derived from industrial eggshell. J. Environ. Manag. 164, 137-145.

Srivastava, M., Ma, L.Q., Santos, J.A.G., 2006. Three new arsenic hyperaccumulating ferns. Sci. Total Environ. 364, 24-31.

Sugama, T., Carciello, N.R., 1995. Sodium phosphate-derived calcium phosphate cements. Cem. Concr. Res. 25, 91-101.

Sun, L., Wu, Q., Liao, K., Yu, P., Cui, Q., Rui, Q., Wang, D., 2016. Contribution of heavy metals to toxicity of coal combustion related fine particulate matter (PM2.5) in Caenorhabditis elegans with wild-type or susceptible genetic background. Chemosphere $144,2392-2400$

Sun, Y., Xia, Y., 2002. Shape-controlled synthesis of gold and silver nanoparticles. Science 298, 2176-2179

Sun, Y., Zhou, Q., Diao, C., 2008. Effects of cadmium and arsenic on growth and metal accumulation of Cd-hyperaccumulator Solanum nigrum L. Bioresour. Technol. 99, 1103-1110.

Sun, Z., Wang, L., Liu, P., Wang, S., Sun, B., Jiang, D., Xiao, F.S., 2006. Magnetically motive porous sphere composite and its excellent properties for the removal of pollutants in water by adsorption and desorption cycles. Adv. Mater. 18, 1968-1971.

Suzuki, T, Niinae, M. Koga T. Akita, T Ohta, M., Choso, T, 2014. EDDS-enhanced electrokinetic remediation of heavy metal-contaminated clay soils under neutral $\mathrm{pH}$ conditions. Colloids Surf. A Physicochem. Eng. Asp. 440, 145-150.

Swift, P., Kinoshita, H., Collier, N.C., Utton, C.A., 2013. Phosphate modified calcium aluminate cement for radioactive waste encapsulation. Adv. Appl. Ceram. 112, 1-8.

Sylvain, B., Mikael, M.H., Florie, M., Emmanuel, J., Marilyne, S., Sylvain, B., Domenico, M. 2016. Phytostabilization of As, $\mathrm{Sb}$ and $\mathrm{Pb}$ by two willow species (S. viminalis and $S$. purpurea) on former mine technosols. Catena 136, 44-52.

Tiwari, K.K., Singh, N.K., Patel, M.P., Tiwari, M.R., Rai, U.N., 2011. Metal contamination of soil and translocation in vegetables growing under industrial wastewater irrigated agricultural field of Vadodara, Gujarat, India. Ecotoxicol. Environ. Saf. 74 $1670-1677$.

Török, A., Gulyás, Z., Szalai, G., Kocsy, G., Majdik, C., 2015. Phytoremediation capacity of aquatic plants is associated with the degree of phytochelatin polymerization. J. Hazard. Mater. 299, 371-378.

Torres, L.G., Lopez, R.B., Beltran, M., 2012. Removal of As, $\mathrm{Cd}, \mathrm{Cu}, \mathrm{Ni}, \mathrm{Pb}$, and $\mathrm{Zn}$ from a highly contaminated industrial soil using surfactant enhanced soil washing. Phys. Chem. Earth 37-39, 30-36.

Tóth, G., Hermann, T., Da Silva, M.R., Montanarella, L., 2016. Heavy metals in agricultural soils of the European Union with implications for food safety. Environ. Int. 88, 299-309.

Tripp, S.L., Pusztay, S.V., Ribbe, A.E., Wei, A., 2002. Self-assembly of cobalt nanoparticle rings. J. Am. Chem. Soc. 124, 7914-7915.

U.S. Environmental Protection Agency (USEPA), 2004. Risk assessment guidance for superfund (Rags). Human Health Evaluation Manual (Part E, Supplemental Guidance for Dermal Risk Assessment) Interim. I Available at:. http://www.epa.gov/oswer/ riskassessment/ragse/.

Ucaroglu, S., Talinli, İ., 2012. Recovery and safer disposal of phosphate coating sludge by solidification/stabilization. J. Environ. Manag. 105, 131-137.

Udovic, M., Lestan, D., 2010. Fractionation and bioavailability of $\mathrm{Cu}$ in soil remediated by EDTA leaching and processed by earthworms (Lumbricus terrestris L.). Environ. Sci. Pollut. Res. 17, 561-570.

Ullah, A., Heng, S., Munis, M.F.H., Fahad, S., Yang, X., 2015. Phytoremediation of heavy metals assisted by plant growth promoting (PGP) bacteria: A review. Environ. Exp. Bot. 117, 28-40.

United Nations Environmental Protection/Global Program of Action (UNEP/GPA), 2004f. Why the marine environment needs protection from heavy metals. Heavy Metals. UNEP/GPA.

Usman, A.R.A., Mohamed, H.M., 2009. Effect of microbial inoculation and EDTA on the uptake and translocation of heavy metal by corn and sunflower. Chemosphere 76, 893-899.

Valentín-Vargas, A., Root, R.A., Neilson, J.W., Chorover, J., Maier, R.M., 2014. Environmental factors influencing the structural dynamics of soil microbial communities during assisted phytostabilization of acid-generating mine tailings: a mesocosm experiment. Sci. Total Environ. 500, 314-324

Vallino, M., Greppi, D., Novero, M., Bonfante, P., Lupotto, E., 2009. Rice root colonisation by mycorrhizal and endophytic fungi in aerobic soil. Ann. Appl. Biol. 154 195-204. 
Van Huysen, T., Abdel-Ghany, S., Hale, K.L., LeDuc, D., Terry, N., Pilon-Smits, E.A.H., 2003 Overexpression of cystathionine-gamma-synthase enhances selenium volatilization in Brassica juncea. Planta 218, 71-78.

Venegas, A., Rigol, A., Vidal, M., 2015. Viability of organic wastes and biochars as amendments for the remediation of heavy metal-contaminated soils. Chemosphere 119 190-198.

Verbruggen, N., Hermans, C., Schat, H., 2009. Molecular mechanisms of metal hyperaccumulation in plants. New Phytol. 181, 759-776.

Verkleij, J.A.C., Golan-Goldhirsh, A., Antosiewisz, D.M., Schwitzguébel, J.P., Schröder, P. 2009. Dualities in plant tolerance to pollutants and their uptake and translocation to the upper plant parts. Environ. Exp. Bot. 67, 10-22.

Virkutyte, J., Sillanpaa, M., Latostenmaa, P., 2002. Electrokinetic soil remediation - critical overview. Sci. Total Environ. 289, 97-121.

Vocciante, M., Caretta, A., Bua, L., Bagatin, R., Ferro, S., 2016. Enhancements in ElectroKinetic remediation technology: Environmental assessment in comparison with other configurations and consolidated solutions. Chem. Eng. J. 289, 123-134.

Vogel-Mikuš, K., Pongrac, P., Kump, P., Nečemer, M., Regvar, M., 2006. Colonisation of a Zn, $\mathrm{Cd}$ and $\mathrm{Pb}$ hyperaccumulator Thlaspi praecox Wulfen with indigenous arbuscular mycorrhizal fungal mixture induces changes in heavy metal and nutrient uptake. Environ. Pollut. 139, 362-371.

Walker, D.J., Clemente, R., Bernal, M.P., 2004. Contrasting effects of manure and compos on soil $\mathrm{pH}$, heavy metal availability and growth of Chenopodium album L. in a soil contaminated by pyritic mine waste. Chemosphere 57, 215-224.

Wan, X., Lei, M., Yang, J., 2016. Two potential multi-metal hyperaccumulators found in four mining sites in Hunan Province, China. Catena http://dx.doi.org/10.1016/j. catena.2016.02.005

Wang, H., Ma, J.W., Fan, X.Y., 2007. Research progress on enhancement of in situ remediation of heavy metal by electrokinitics. Ecol. Environ. Sci. 16 (1), 223-227.

Wang, Q., Liu, J., Cheng, S., 2015. Heavy metals in apple orchard soils and fruits and their health risks in Liaodong Peninsula, Northeast China. Environ. Monit. Assess. 187 (1) $1-8$.

Wawrzyński, A., Kopera, E., Wawrzyńska, A., Kamińska, J., Bal, W., Sirko, A., 2006. Effects of simultaneous expression of heterologous genes involved in phytochelatin biosynthesis on thiol content and cadmium accumulation in tobacco plants. J. Exp. Bot. 57, 2173-2182.

Wei, C., Ge, Z., Chu, W., Feng, R., 2015. Speciation of antimony and arsenic in the soils and plants in an old antimony mine. Environ. Exp. Bot. 109, 31-39.

Wei, M., Chen, J., Wang, X., 2016. Removal of arsenic and cadmium with sequential soil washing techniques using Na2EDTA, oxalic and phosphoric acid: optimization conditions, removal effectiveness and ecological risks. Chemosphere 156, 252-261.

Weyens, N., van der Lelie, D., Taghavi, S., Newman, L., Vangronsveld, J., 2009a. Exploiting plant-microbe partnerships to improve biomass production and remediation. Trends Biotechnol. 27, 591-598.

Weyens, N., van der Lelie, D., Taghavi, S., Vangronsveld, J., 2009b. Phytoremediation: plant-endophyte partnerships take the challenge. Curr. Opin. Biotechnol. 20, 248-254.

Wong, C.K.E., Cobbett, C.S., 2009. HMA P-type ATPases are the major mechanism for rootto-shoot Cd translocation in Arabidopsis thaliana. New Phytol. 181, 71-78.

Wu, Z., Zhao, X., Sun, X., Tan, Q., Tang, Y., Nie, Z., Qu, C., Chen, Z., Hu, C., 2015. Antioxidant enzyme systems and the ascorbate-glutathione cycle as contributing factors to cadmium accumulation and tolerance in two oilseed rape cultivars (Brassica napus L.) under moderate cadmium stress. Chemosphere 138, 526-536.

Xiong, D., Fang, T., Yu, L., Sima, X., Zhu, W., 2011. Effects of nano-scale TiO2, ZnO and thei bulk counterparts on zebrafish: acute toxicity, oxidative stress and oxidative damage. Sci. Total Environ. 409, 1444-1452.

Xiong, J., He, Z., Liu, D., Mahmood, Q., Yang, X., 2008. The role of bacteria in the heavy metals removal and growth of Sedum alfredii Hance in an aqueous medium. Chemosphere 70 (3), 489-494.

Xiong, T., Austruy, A., Pierart, A., Shahid, M., 2016a. Kinetic study of phytotoxicity induced by foliar lead uptake for vegetables exposed to fine particles and implications for sustainable urban agriculture. J. Environ. Sci. 1-12.
Xiong, T, Dumat C, Pierart, A, Shahid, M, Kang Y, Li, N., Bertoni, G, Laplanche, C., 2016b. Measurement of metal bioaccessibility in vegetables to improve human exposure assessments: field study of soil-plant-atmosphere transfers in urban areas, South China. Environ. Geochem. Health http://dx.doi.org/10.1007/s10653-016-9796-2.

Xiong, T., Leveque, T., Shahid, M., Foucault, Y., Mombo, S., Dumat, C., 2014. Lead and cadmium phytoavailability and human bioaccessibility for vegetables exposed to soil or atmospheric pollution by process ultrafine particles. J. Environ. Qual. 43, 1593.

Xu, X., Zhao, Y., Zhao, X., Wang, Y., Deng, W., 2014. Sources of heavy metal pollution in agricultural soils of a rapidly industrializing area in the Yangtze Delta of China. Ecotoxicol. Environ. Saf. 108, 161-167.

Yadav, S.K., 2010. Heavy metals toxicity in plants: An overview on the role of glutathione and phytochelatins in heavy metal stress tolerance of plants. South African J. Bot. 76 , 167-179.

Yang, L., Huang, B., Hu, W., Chen, Y., Mao, M., Yao, L., 2015. The impact of greenhouse vegetable farming duration and soil types on phytoavailability of heavy metals and their health risk in eastern China. Chemosphere 103, 121-130.

Yang, Z., Zhang, Z., Chai, L., Wang, Y., Liu, Y., Xiao, R., 2016. Bioleaching remediation of heavy metal-contaminated soils using Burkholderia sp. Z-90. J. Hazard. Mater. 301 $145-152$.

Yao, Z., Li, J., Xie, H., Yu, C., 2012. Review on remediation technologies of soil contaminated by heavy metals. Procedia Environ. Sci. 16, 722-729.

Yu, Y., Zhang, S., Huang, H., Luo, L., Wen, B., 2009. Arsenic accumulation and speciation in maize as affected by inoculation with arbuscular mycorrhizal fungus Glomus mosseae. J. Agric. Food Chem. 57, 3695-3701.

Zhang, D., Wei, S., Kaila, C., Su, X., Wu, J., Karki, A.B., Young, D.P., Guo, Z., 2010. Carbon-stabilized iron nanoparticles for environmental remediation. Nanoscale 2, 917-919.

Zhang, F., Zhang, H., Xia, Y., Wang, G., Xu, L., Shen, Z., 2011. Exogenous application of salicylic acid alleviates cadmium toxicity and reduces hydrogen peroxide accumulation in root apoplasts of Phaseolus aureus and Vicia sativa. Plant Cell Rep. 30, $1475-1483$.

Zhang, Y., Liu, J., Zhou, Y., Gong, T., Wang, J., Ge, Y., 2013. Enhanced phytoremediation of mixed heavy metal (mercury)-organic pollutants (trichloroethylene) with transgenic alfalfa co-expressing glutathione S-transferase and human P450 2E1. J. Hazard. Mater. 260, 1100-1107.

Zhao, F.J., Lombi, E., Breedon, T., McGrath, S.P., 2000. Zinc hyperaccumulation and cellular distribution in Arabidopsis halleri. Plant Cell Environ. 23, 507-514.

Zhao, Z., Xi, M., Jiang, G., Liu, X., Bai, Z., Huang, Y., 2010. Effects of IDSA, EDDS and EDTA on heavy metals accumulation in hydroponically grown maize (Zea mays, L.). J. Hazard. Mater. 181, 455-459.

Zheng, C., Wang, P.P., 2002. A field demonstration of the simulation optimization approach for remediation system design. Ground Water 40, 258-265.

Zhu, L., Ding, W., Feng, L., Kong, J., Xu, Y., Xu, J., Yang, X., 2012. Isolation of aerobic denitrifiers and characterization for their potential application in the bioremediation of oligotrophic ecosystem. Bioresour. Technol. 108, 1-7.

Zhu, Y.G., Pilon-Smits, E.A.H., Zhao, F.J., Williams, P.N., Meharg, A.A., 2009. Selenium in higher plants: understanding mechanisms for biofortification and phytoremediation. Trends Plant Sci. 14, 436-442.

Zhu, Y.L, Pilon-Smits, E A Tarun, A.S, Weber, S.U, Jouanin, L. Terry, N., 1999. Cadmium tolerance and accumulation in Indian mustard is enhanced by overexpressing gamma-glutamylcysteine synthetase. Plant Physiol. 121, 1169-1178.

Zouari, M., Elloumi, N., Ahmed, C.B., Delmail, D., Rouina, B.B., Abdallah, F.B., Labrousse, P., 2016. Exogenous proline enhances growth, mineral uptake, antioxidant defense, and reduces cadmium-induced oxidative damage in young date palm (Phoenix dactylifera L.). Ecol. Eng. 86, 202-209. 